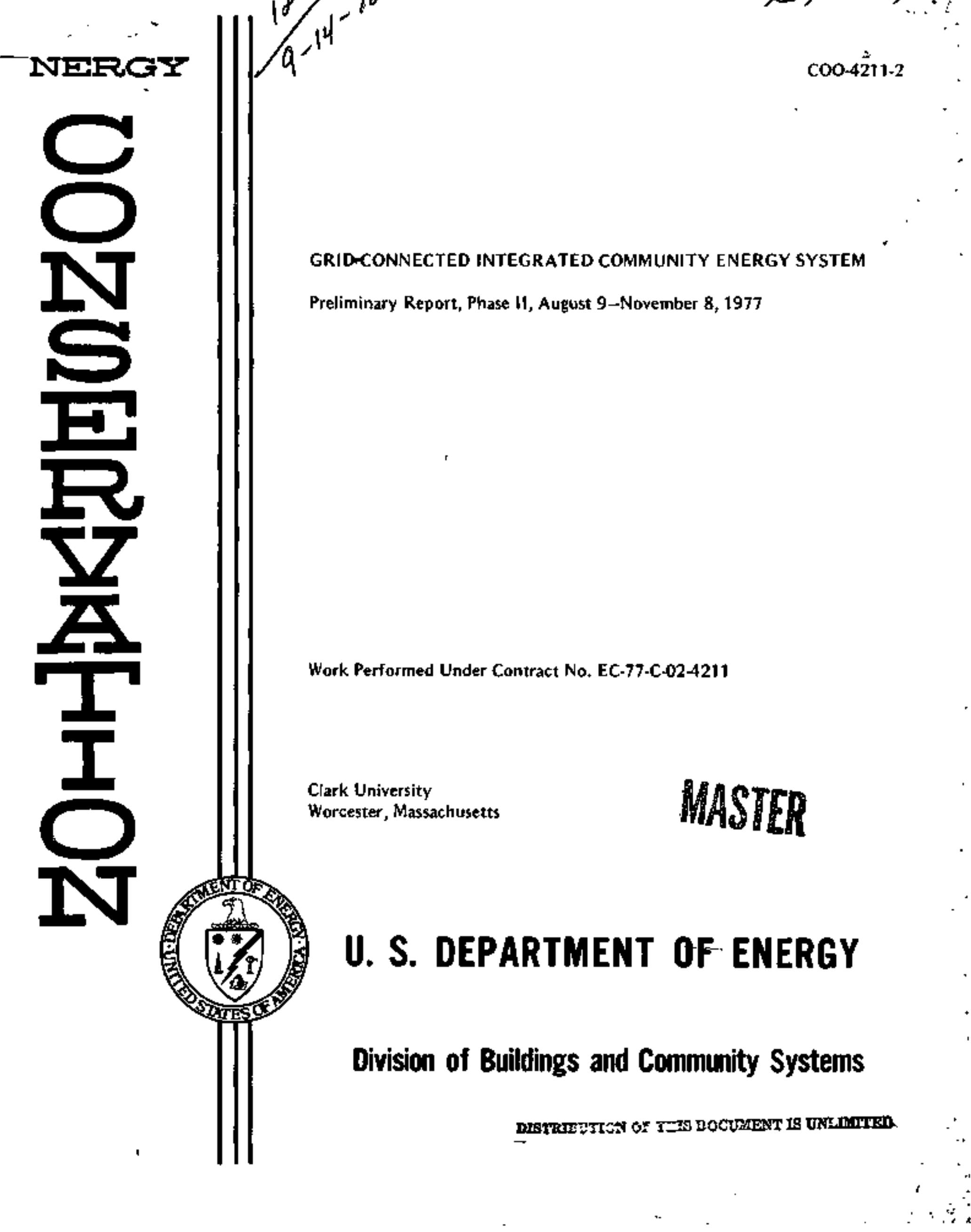




\section{DISCLAIMER}

This report was prepared as an account of work sponsored by an agency of the United States Government. Neither the United States Government nor any agency Thereot, nor any of their employees, makes any warranty, express or implied, or assumes any legal liability or responsibility for the accuracy, completeness, or usefulness of any information, apparatus, product, or process disclosed, or represents that its use would not infringe privately owned rights. Reference herein to any specific commercial product, process, or service by trade name, trademark, manufacturer, or otherwise does not necessarily constitute or imply its endorsement, recommendation, or favoring by the United States Government or any agency thereof. The views and opinions of authors expressed herein do not necessarlly state or reflect those of the United States Government or any agency thereof. 


\section{DISCLAIMER}

Portions of this document may be illegible in electronic image products. Images are produced from the best available original document. 


\section{NOTICE}

This reporl wạs preputed as an actount of work sponsored by the United States Government. Neithes the United Stutes nar the Uniited \$lates Department of Energy, nor any of their employess, nor any of their contractors, subcoptractors, or their employees, makes any wastanty, express or implied, or assumes any legal liability or responsibility for the accuracy, completeness or uselulness of any information, apparatus, product or proccss disclosed, or represcrits that its use would not infringe privately owned rights.

This report has been printed directly from copy supplied by the originating organization. Aluhough the copy supplied may not in paft or whole maet the slandards for acceplable reproducible copy, it has been used for reproduction to expedite distribution and utailablity of the information being reported.

Avalable Irom the National Technical Information Service, U. S. Depastment of Commerce, Springteld, Virginia 22161.

Price: Paper Copy \$7.25

Microfiche $\$ 3.00$ 
The reader ohould note that the draft cantract between Clark and th- Marachuaetro Electric Company preaented in Appendix 2B bas been - superaeded by a new draft wich, hawever, arrived too late to be included in this report. Because of our uncertainty about the nature of the final agreement, the economic analyoie presented in this report is based on the undertcandinge in effect at the end of Phane $I$. While the general concluaions te present are otill correct, the reader should refer to the Phase II Final Regort tor all details. 
GRID-CONNECTED INTEGRATED

COMANINITY ENERGY SYSTEM

\section{PRELIMINARY QEPORT}

PHASE I I

FOR PERTOD

AUGUST 9, 1977, rO NOVEKBER 8, 1977
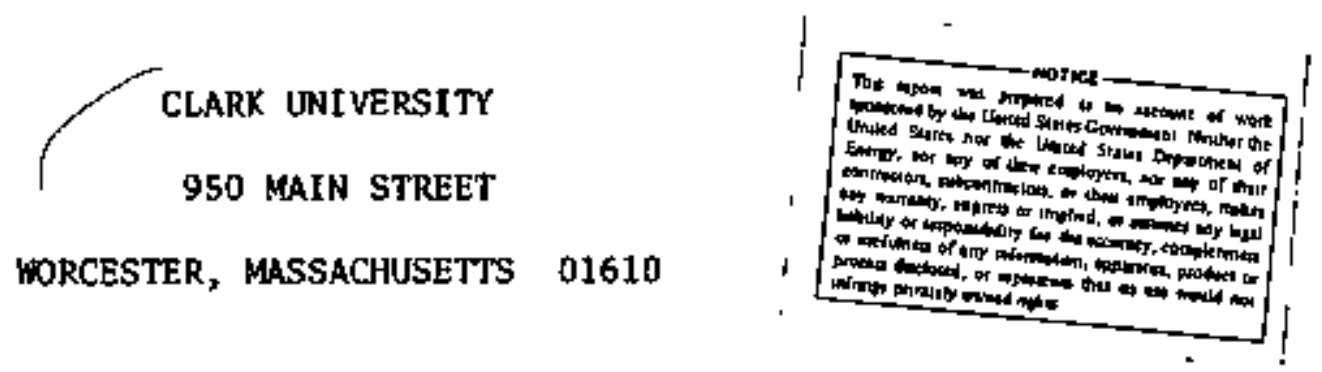

PREPARED FOR

THE U. S. DEPARTMENT OF ENERGY

UNDER CONTRACT NO, EC-77-C-02-4211, AO01

PREPARED BY

CLARK UNIVERSITY

THERMO ELECTRON CORP.

FITZEMEYER AND TOCCI, INC.

BOZENHARD COMPANY

SHEPHERD ENGINEERING

NEW ENGLAND ELECTRIC SYSTEN

L. G. COPLEY ASSOCIATES

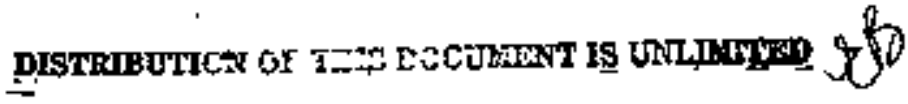




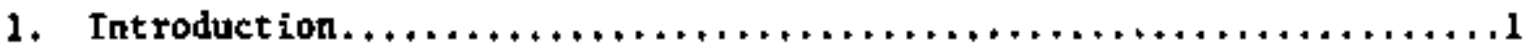

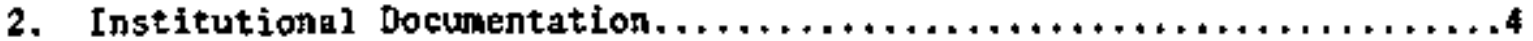

2.0 Introduction. ...................................

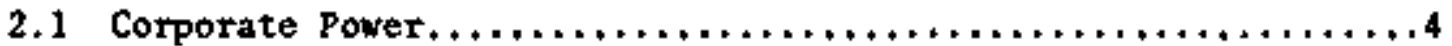

2.2 Interchange Terms................................4

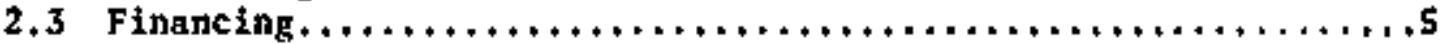

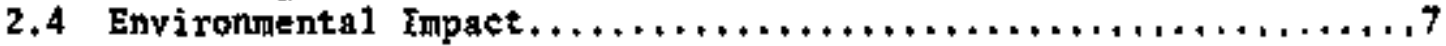

3. Preliminary Design Analysis $\ldots \ldots \ldots \ldots \ldots \ldots \ldots \ldots \ldots \ldots \ldots \ldots \ldots \ldots \ldots \ldots \ldots, \ldots$

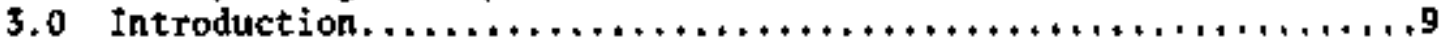

3.1 Energy Load Profiles.............................,

3.2 Design options and Final Choice of Engine...............11

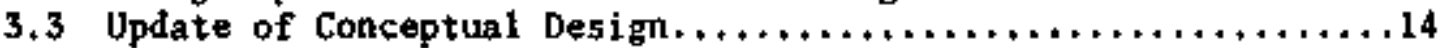

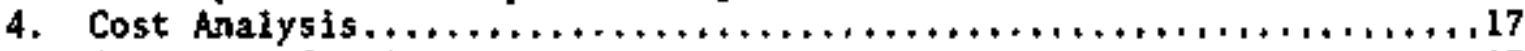

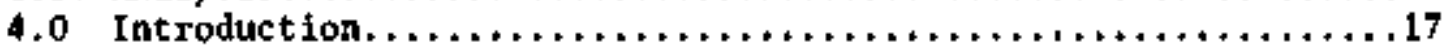

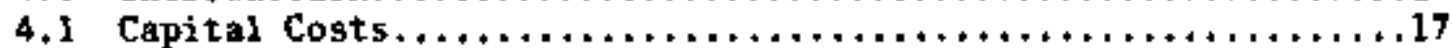

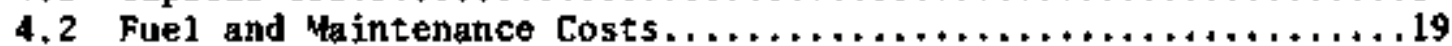

4.3 Comparison with the Conventional systen.................20

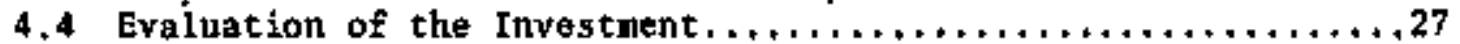
Appendices

1 A Letter from Lawrence Landry, Vice President of Business

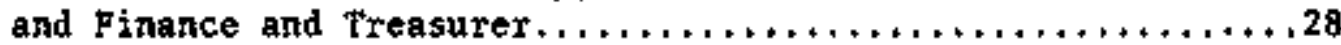

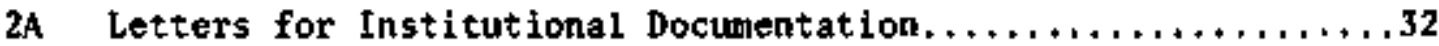

2B Present Retail Electricity Rate and Standby Tems, .........38

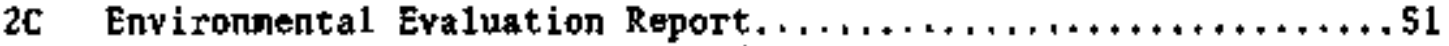

3A Engine Operating Experience and Guarantes $\ldots \ldots \ldots \ldots \ldots \ldots \ldots \ldots$. $\ldots \ldots$

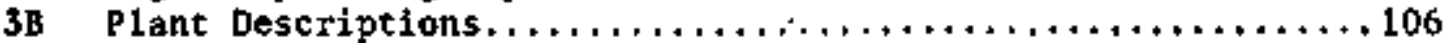

$3 C$ Performance of the Candidate Systems..................

3D Heavy Fue1 Treatment Systern, ...................... 121

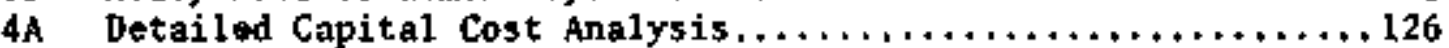

4B Operation and Haintenance Costs.................. 131 


\section{TABLES}

2.4-1 Estinated Air Pollution Impact--Present System and Proposed Grid-Connected ICEs...........................

3.3-1 Perfomance Characteristics of Three Diesel Engines.............15

$3,3-2$

4.1-1

4.2-1

4.2-2

4.3-1

4,3-2

4.3-3

4.3-4

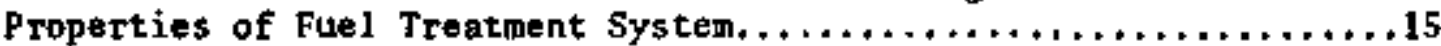

2C-EIA-1

2C-EIA- 2

2C-EIA-3

2C-EIA-4

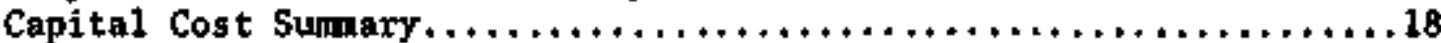

Fuel Cost and Heat Credit. $\ldots \ldots \ldots \ldots \ldots \ldots \ldots \ldots \ldots \ldots \ldots \ldots \ldots \ldots \ldots$

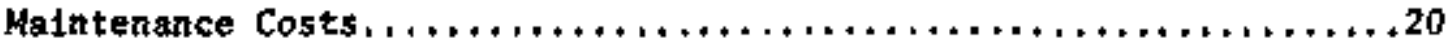

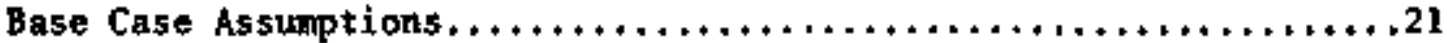

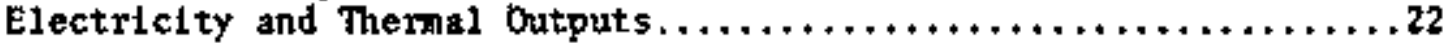

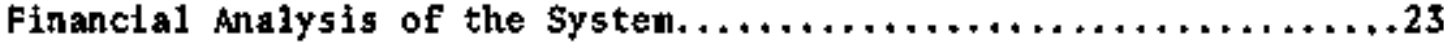

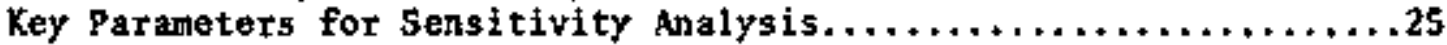

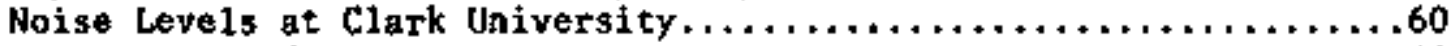

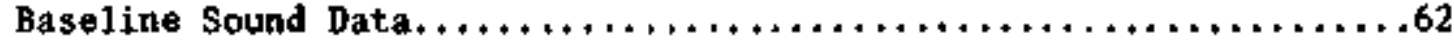

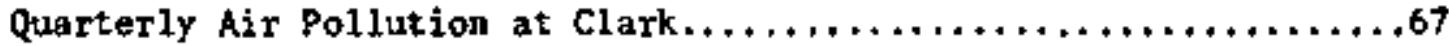

Estimated Air Pollution Impact--Present Systen and

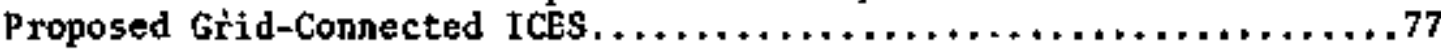

4A-1

4A-2

$4 \mathrm{~B}-1$

48-2

Capt tal Cost Analysis inside New Building. ................

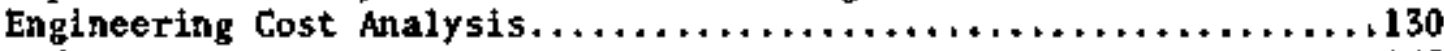

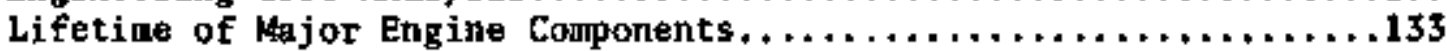
Manufacturers" Recomnended limits for Vanadium and

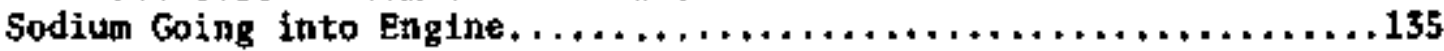

4B-3 Summary of Diesel Engine Operation and Maintenance Costs........136

48-4

Summary of System Operation and Maintenance Costs.

\section{FIGURFS}

3. 1-1

3. 1-2

3.1-3

3. 3-1

4.3-1

4. 3-2

2C-EIA-1

2C-EIA-2

2C-EIA-3

3C- 1

3C- 2

$3 \mathrm{C}-3$

$3 C-4$

3C-5

3C- 6

3D-1

30-2

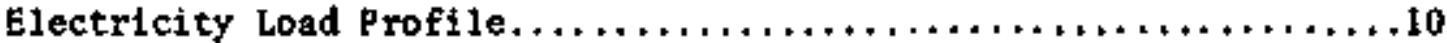

Revised thermal Load Profile $\ldots \ldots \ldots, \ldots, \ldots, \ldots, \ldots, \ldots, \ldots, \ldots, \ldots 10$

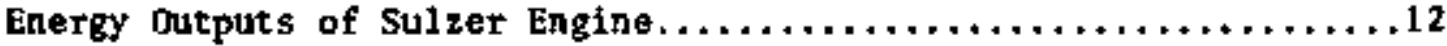
Location of Proposed building and Goddard Memorial,

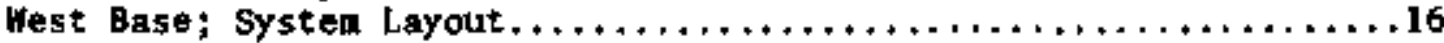

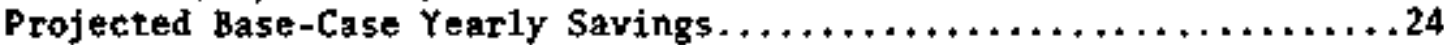

Sensitivity of Sulzer Savings to Variation of Parameters.........26

Plan of the East Wing of Jonas Clark Hall $\ldots \ldots \ldots, \ldots \ldots \ldots \ldots \ldots, \ldots 7$

Stean Distribution Systen at Clark University $\ldots \ldots \ldots \ldots \ldots \ldots \ldots . \ldots 6$

Illustration of Energy Consumption at Clark since $1970 \ldots \ldots \ldots \ldots, 63$

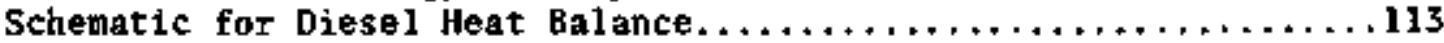

Heat Balance: Sulzer, $100 \%$ Load...........................116

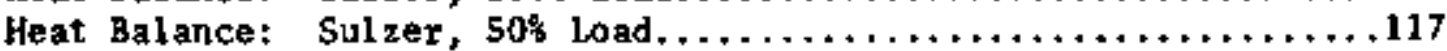

Heat Balance: Superior, $100 \%$ Load, .........................118

Heat Balance: Superior, 50 boad........................119

Heat Balance: Fairbanks-Horse, 100 h Lad.....................

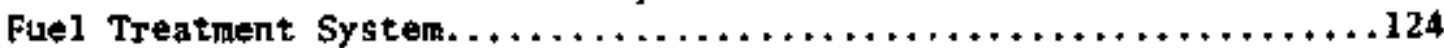

Key to System Flow Diagram............................. 


\section{INTRODUCTION}

Clark University represents an attractive site for demonstration of cogeneration. The principal features of the site are as follows,

(1) Clark is located in New England, a region that depends on imported oil for most of its electric generation, and has some of the highest electric prices in the nation.

(2) Clark, with a 1.5 ss peak electrical demand, offers a variety of demand patterns in its $30+$ major buildings.

(3) Clark already hos an operating steam distribution system which serves its 12-acre canpus.

(4) Clark is serviced currently by the Massachusetts Electric Conpany, an organization that has taken an actjue and creative interest in cogeneration.

In Phase $I$ of the ERDA Demonstration ICES Progran, the tean from Clark University, consisting of representatives fron the University, TheminElectron Corporation, Fitzemeyer and Tocci, and Massachusetts Electric, reported the following results:

(1) The systen of choice for ICES demonstration at clark is a diese 1 generator sized at about Clark's peak electric demand.

(2) In order to avoid placing additional denand on scarce light-oil sources, such a generator should burn 16 oil if at all possible.

(3) Through Massachusetts Electric's agreement to purchase excess power at about the cost of displaced fuel, the system can run at nearly full capacity the yerr round, sell $40 \%$ of its output to the utility, and receive backup as needed from the utility.

(4) Under a variety of passible financing plans, and reasonable projections of fuel costs, the system will deliver for Clark an internal rate of return of 15-20\%.

(5) There appear to be no institutional or environmental problens that would prevent operation of the systen as planned.

In this report we provide an update on a number of issues that were incompletely resolved in the Phase I report.

In Section 2 we provide additional documentation on institutional 
issues involved In the proposed demonstration at Clark, particularly as follows.

(1) According to the best information available fron the State Attorney General's office, there will be no problem with Clark's sale of electricity to the utllity.

(2) We have now a draft agreement with Hassachusetts Electric that. both we and the utility can support. It follows the general outlines digcussed previously. Hecause of utility support, we expect no difficulty in obtaining final approval from the state Departnent of Public Utilities (DPU).

(3) After further investigation of financing possibilities we are now assured that we can obtain 6-74 HEFA financing. This will be sufficient to nake the project viable. At the same tine, the project would be ever more attractive to us if anticipated federal loan programs at $3 t$ interest receive Congressionsl approval, and if we qualify, as we expect, for support from tluese.

(4) A revision of environmental impact assessments shows no difflculties with the proposed project.

In Section 3 we provide a preliminary design onalysis that clearly defines our choice of engine and provides revised operating data in light of additional load profile studies. In particular we now find:

(1) A Sulzer H6-oil-burning $1405 \mathrm{~kW}$ diesel is the system of choice.

(2) The engine should be housed in a separate building in close proxinity to the existing central boiler and stear distribution points.

(3) As a result of detailed sumer load studies the engine as specified can be operated with higher capacity factors than anticipated in Phase I.

In Section 4 we provide a revised cost estimate using information developed in Sections 2 and 3 . Coupared to the Phase I report, we find no significant change in net cash flow, and an internal rate of return of $15 \%$. In reaching this conclusion we note that increased capital charges roughly cancel decreased fuel costs arising from use of 6 oil and higher engine efficiency.

Our overall conclusion is therefore that, though some details have changed, the Clark demonstration project continues to appear highly attractive. 
It should be attractive to EROA becaise the grid-connection plays a pivotal role both in the choice of system and in the energy savings; Approxinately $40 \%$ of the electricity output is to be exported to the utility and thus $40 \%$ of the oil savings cones directly from the grid-connectlon.

For Clark, the tCES is especially attractive as an investment, for reasons that go beyond its satisfactory rate of return. As discussed by l. Landry, the University's chief business officer (see Appendix 1A), the ICES offers protection against inflating energy costs by stabilizing half of the University's electrical cost's. Additionally, ownership of the ICES alnost conpletely tnsulates clark fron possibte unfavorable changes in the utility retail rate structure. Furthemore, the demonstration would increase Clark's national visibility and add to the prograla in energy studies. Therefore Charles Sanders, Chairman of the Board of Trustees, and $E$, Landry are confident that the Trustees will vote to construct the ICES, provided the results presented here are verified in the rest of phase II. 


\section{INSTITUTIONAL DOCUMENTATION}

\subsection{Introduction}

In Phase I we identified several institutional issues which had to be resolved. These critical issues were (1) whether the University has the power to sell electricity, (2) whether we could nake suitable arrangenents for interchange with Massachusetts Electric that would be approved by the Massachusetts Department of Public Utilities, (3) whether we could find a suitable mode of financing the system, and (4) whether the plant would neet enviromental and zoning requirements. We can now report that each of these 1ssues has been resolved or is at least well on the way toward resolution.

\subsection{Corporate Power}

We had initially hoped to obtain a formal ruling fron the Attorney General on whether the Untversity as a charitabie Institution has the power to sell electricity. However, since we are not a government agency, we are not entitled to a formal ruling, Ve have instead been given an informgl opinion by the division in the Attorney General's office responsible for overseeing charitable institutions. In the opinion of Assistant Attomer General Reedy (1etter in Appendix 2A), "the distribution of excess energy to a public utility would be incidental to the prinary purposes [of the projectl, and would not affect the charitable status of the University." According to the University Counsel, Richard Mirick, since this is from the division of the state government charged with supervising the conduct of charitable institutions, it is sufficient assurance that the University's power to sell electricity will not be challenged [see Mirick's letter in Appendix 2A).

\section{2,2 Interchange Terans}

The Massachusetts Electric Company has reaffimed its intent to offer Clark terms of interchange. A letter from Mass. Electric President William Cadigan appears in Appendix 2A. A preliminary draft of the contract is given in Appendix 2B. Mass. Electric has assured Clark that while there may be minor nodifications in the detalls of the agreement, no changes will be made that will be deleterious to the demonstration. 
The agreement enpowers Clark to use directly as much of the ICES eiectricity output as Clark needs. Only when the ICES output is insufficient for the Clark denand will Clark purchase electricity fron Massachusetts Electric. Those purchases will be at the current published energy rate, C-22, together with a monthly distribution capacity charge based on contracted denand. The distribution charge is based on Mass. Electric's present distribution systen costs. The present $C-22$ rate is also shown in Appendix 2B. When Clark nakes more electricity than it can use, the excess will be sold to the utility for a price closely approximating the cost of displaced fuel. This price depends on time of day; thus there $w 11$ be two prices, one for weekdays from 7:00 A.M. to 11:00 p.m., the other for the renaining times. For convenience, the price will be factored into two pieces, a nultiplier tines the average wholesale fuel cost. There will be two multipliers, one for peak and the other for off-peak sales. In 1974 the peak multiplier would have been 1.3; the off-peak multiplier would have been 1.06. The multipliers will be revaluated periodically to take account of changes in the $n i x$ of generating costs. Our estimate is that based on 1977 data the multipliers will be about 5\% greater than the 1975 vatues.

The terns of interchange must be approved by the Kassachusetts Department of Public Utilities. We have spoken with the DPU and expect soon to have a timetable for obtaining DPU approval of the proposed terms. We anticipate so difficulty in obtaining approval since Massachusetts Electric strongly supports the demonstration project.

\subsection{Financing}

In Phase I we identified four alternative modes of financing the ICES, These were borrowing from the endowment, a commercial loan, a Health and Education Facilities Authority (HEFA) tax-exenpt bond issue, and federal loan program. We found that the last two possibilities were distinctly preferable, but we were not able to definitely detemine their feasibility. At this writing we can report in relation to federal programs that we would have been eligible under last year's Hill loan program had we been ready to begin construction soon enough. The hDD progran provides loans for 
investments for the purpose of conserving energy in dormitories and dining facilities. Since about half of Clark's heat and electricity go to domitories and dining (see Phase I Report, Tables 1.2.4-2 and 1.2.4-3), this program, if funded for the coming year, could provide financing at 3 for for half the project cost. Unfortunately, no decision has been made yet an whether the progran will be funded for the coning year. A parallel program for acadenic buildings under the Office of Education was not funded last year, and its prospects for this year are not easy to estimate, We are prepared to submit applications for either program the moment Congress appropriates funds to it.

Because federal financing is not certain, we have spent considerable effort in seeking approval for a HEFA bond issue. As a first step we have reta1ned an investment broker, Marsom Pratt of Adams, Harkness and Hill, to handle the bond issue. Mr. Pratt is investnent counse1 to HEFA. In 1976 he developed the successful band issue for Clark's new Student Activities Center and he is confident that a HEFA bond issue can be developed for the ICES and that it will be approved by HEFA. He recommends that we place the bonds privately, instead of having a public issue. For a private issue, Clark will not need to tie up resources in securing the bonds, and epproval and placement w111 be easier to obtain. We will, however, have to pay a higher interest rate than the $5 \%$ we paid on the public issue for the Student Activities Center. The interest charges will not exceed 78 in any event. HEFA approval for the bond issue must cothe in two stages. We expect to obtain preliminary approval for the bond issue next month. Preliminary approval authorizes the preparation of a prospectus for the bond issue. We expect to obtain final approval for the bond issue after a review of the proposed prospectus. The prospectus can, however, be completed only with the preliminary design results of Phase II; consequently, final approval of the bond issue can only be obtained after the completion of Phase II. At the same time Pratt assures us that, if the cost analysis presented in part IV of this report is confirmed in the rest of Phase 11 , there will be no difficulty in obtaining final approval.

Pratt has also suggested the use of the leveraged lease as another node of financing. This may offer even better terms than the HEFA bond issue. Under this plan an investor would own the facility and lease it to clark. The investor 
would be able to offer good terins because he could take adyantage of tax benefits, investment tax credit, accelerated depreciation, etc., which do not apply to the University. This node of financing was used for the Harvard Hospitals' total energy plant.

To sumpaxize, we feel confldent that we can obtain financing through a HEFA bond issue, and are taking the necessary steps to achieve this, We are continuing to pursue two alternative possibilities which might offer even better terms, namely federal Ioan prograns and a leveraged lease. While we do not regard borrowing fron the endowment as a satisfactory method of longtermt financing, it is technically possible for us to borrow for this purpose, and this provides us with enough flexibility to meet unforeseen shortfa11s.

\subsection{Environmental Inpact}

In Phase I we concluded that there were no insurmountable environmentai barriers to the ICES. That is still our conclusion; however, the selection of a nuber 6-oil-burning engine has changed enission data on two counts,

(1) Emissions fron the 6-burning engine contain appreciably more sulfur dioxide because of the higher sulfur content of *6 oil. While the increase is not enough to put the ICES emissions in violation of the present and anticipated air quality standards, we have, as before, requested and received explicit assurances fron the Central Massachusetts Air Quality Division. (See letter from E. Benoit, Appendix 2A). A comparison of enissions from the ICES and from the present systens is shown in Table 2.4-1.

(2) Because a 6-burning engine requires fuel treatment, we plan discharge of the treatment water in the sewage system. Provided that a settling tank is used to reduce the amount of oil in the discharge, the quantities to be discharged are too smail to cause any problems.

our updated envirommental impact evaluation is given as Appendix 2C. 
Table 2.4-1

Estimated Air Pollution Impact--Pregent System and ?:-oposed Grid-Connected ICES

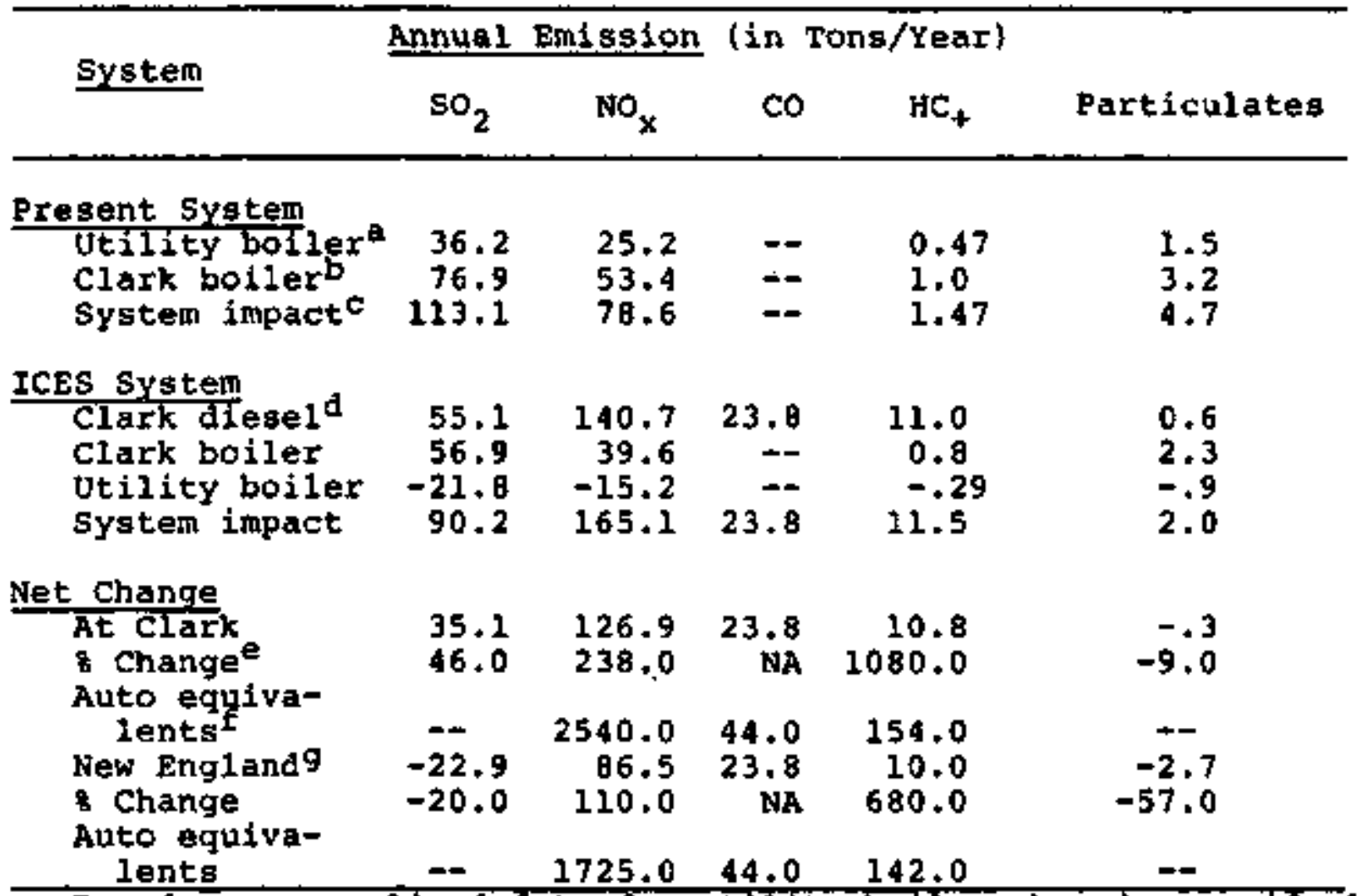

a. Based on generallzed data for veility bollers burning resióual oil with an ash content of 0.048 (by weight), sulphur content of 1.08 (by weight), weight of 7.83 1bs. per gailon, 146,000 Btu per gallon and a Btu to kwh ratio of 10,050 to 1 . Assuming the consumption of $6.8 \times 10^{6}$ per year.

b. Based on the use of residual oil with the same characteristics as specified in note a afd a boiler efficiency of 758. Assuming a thermal load of $109 \times 10^{9}$ Btu per year.

c. Carbon monoxide levels (less than 01 tons) are considered negIigible here.

d. Based on the manufacturer's specifications and the use of $\$ 6$ residual oil with an ash content of 0.048 (by weight), sulphur of 18 (by weight), a weight of 7.03 lbs per gallon, and an energy value of 148,000 atu per gallon. Assuming operation at full capacity for 7750 hours per year.

e. The percent change for carbon monoxide is meaningless since basically none was emitted previously.

f. Auto equivalents are included to provide a means of evaluating the relative significance of the net changes. They are based on EPA's estimates for the average emissions of all the motor vehicles operating in the U.S. in 1976.

g. The New England figures represent the net addittonal emisgions of the Clark ICES and net reduction in the emissions at New England Electric syatem's regidual oil fired generatorg. Assumeg a net reduction in NEEs's oil consumption by 279,000 gallons per year. 


\section{PRELIMINARY DESIGN ANALYSIS}

\subsection{Introduction}

Our preliminery design enalysis incorporates a number of changes from Phase I. We have found that our summer themal demand is not quite what we had estimated, and the correction will enable the ICES to generate somewhat nore heat and electricity. We have decided to locate the generating systew in a new building outside Jonas Clark hall. Most important, we have found a diesel system which neets essentially all of the requirements we defined in the Phase $I$ analysis. It is a Sulzer engine, Model 8 ASL 25/30; it is ebulliently cooled, burns 16 oil, and produces about $1400 \mathrm{~kW}$ of elec. tricity. With the nubber 6-burning engine, we need one more subsysten for the conceptual design, a fuel treatment system.

In the next section, 3.1 , we present our new results on thermal demand, and describe the electrical and theral outputs of the new diesel. In section 3.2 we review the Phase I choice of systen and then give our reasons for selecting the Sulzer engine and the new location. In section 3.3 we describe the changes needed in the conceptual design to acconodate the new engine and location.

\subsection{Energy Load Profiles}

The electricity load profile presented in our Phase I report was based on several years of recorded data. Since our recent data is consistent with the previous records, we have not altered our estimated electricity load profile; it is reproduced in figure 3,1-1. That profile contains an estimated contribution fron the new gym; we will have data on its actual contribution as soon as it begins to be used, in less than a month.

The thermal load profile presented in the Phase I report used estimated sumper thermal demands. We now have data on thermal denand for this suner and this changes somewhat our previous estimate. We have found that at present sumner thermal denand is considerably more uniform than we had estimated. The revised profile is presented in Figure 3.1-2. As with the electrical profile, we have estimated the contribution of the new gyn and we will be able to test this estimate in the next few months. The added denand in sunner nights means that we will be able to operate the ICES, at 
Fig, 3,1-1: [lectrictty Load Profile

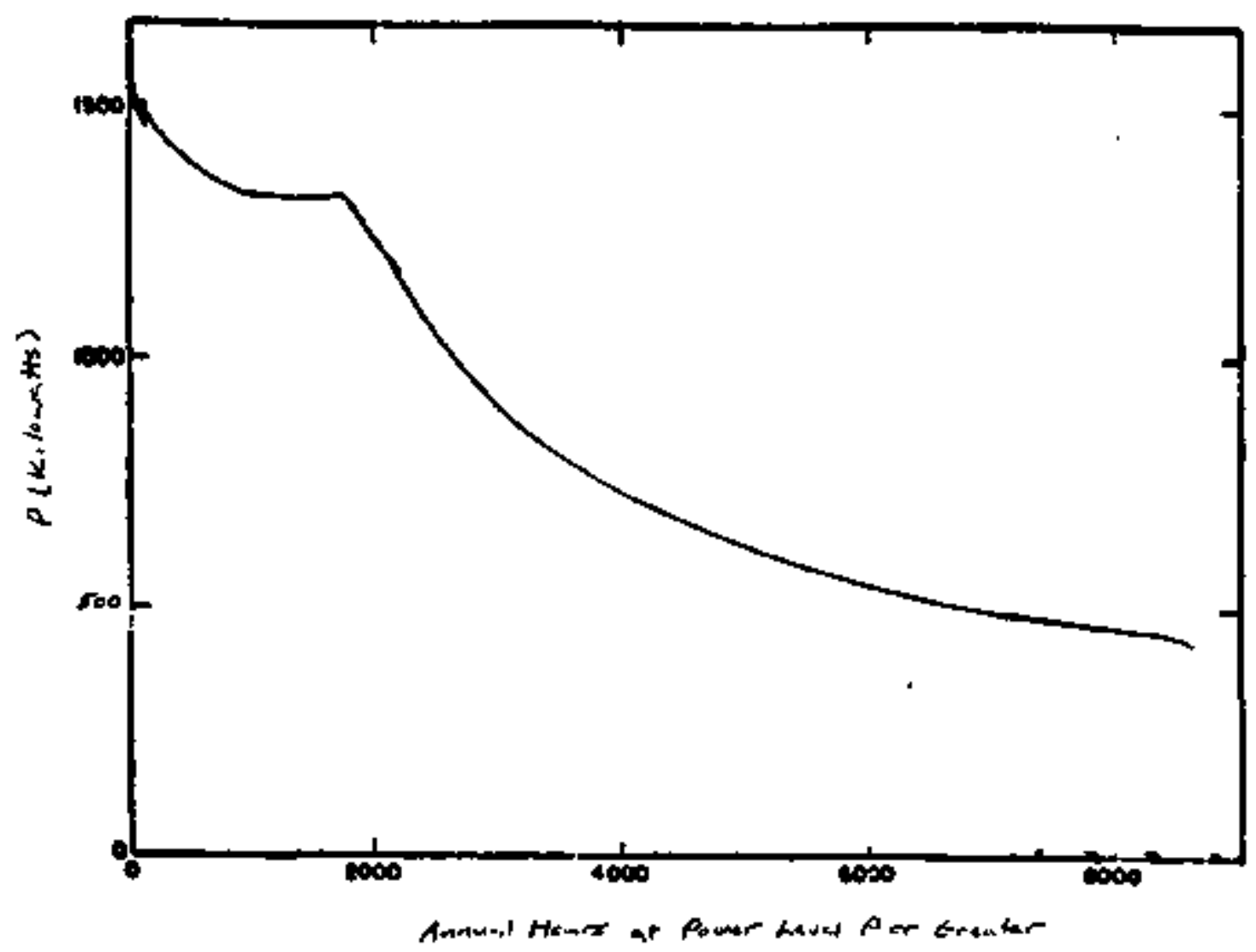

Fig. 3.1-2: Revised Thermal Load Pro:ile

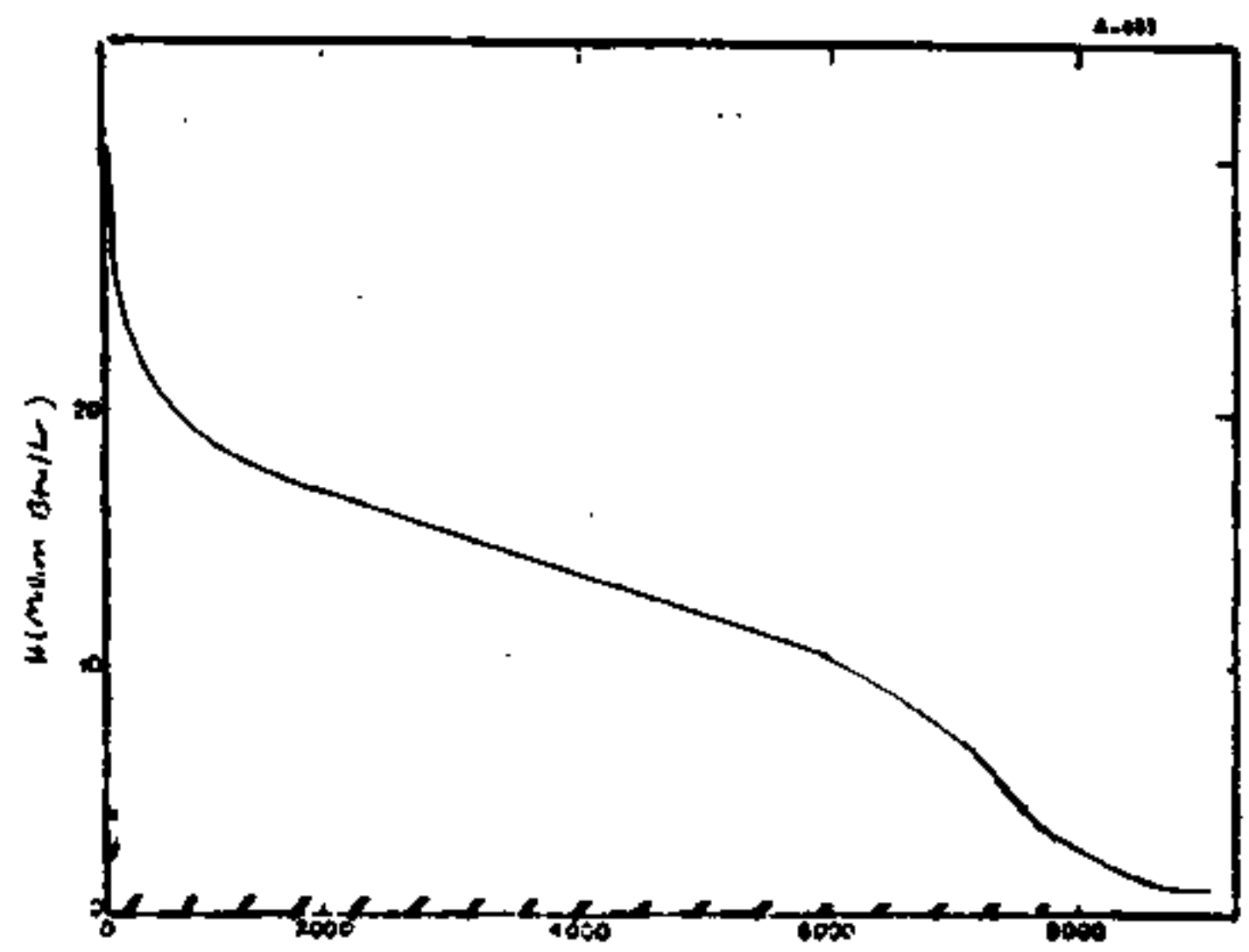


part load, for many sumer nights, and the overall output of the system could be somewhat greater than our previous estinate.

We repeat the themal and electric load proftles in Fig. 3.1-3; shown on these profiles are the electric and thernal outputs of the Sulzer 1405 KW engine. Except for sumer nights and brief periods for naintenance, the engine operates at full load continuously. The overall fuel saving we expect is about 250,000 gals/yr oil saved by Clark and the electric utility. Notice that the grid-connection, in addition to its other benefits, gives rise to about 40 of those-savings.

\subsection{Destgn Options and Final Choice of Engine}

We have decided to put the generating plant in a new building adjacent to the boiler room in the basement of Jonas clark hall. This location is preferable to a location inside Jonas clark, because (1) it avoids najor problems with noise and vibration insulation; (2) it does not el iminate classroon space; (3) it will be much easler to make the demonstration systen accessible and attractive for public viewing. The disadvantage of the choice is that It adds signiflcantly to the capital cost of the project [see section 4.1 and Appendf 4 A). We belfeve that the advantages more than nake up for the extra cost.

In Phase I we concluded that the optinum ICES for Clark would use a single diesel engine, ebulliently cooled, burning residual oil, with a maximun electricity output of about $1500 \mathrm{KW}$ and a maximum recoverable heat output of about 4 million Btu/hr. We reached this conclusion after exanining a variety of diesel engines in various configurations along with representative stean turbine systens and gas turbine systems. We have reviewed that analysis for this report and found it sti11 correct. Steam turbines small enough for Clark's heat denand simply do not make enough electrictty to finance then. Gas turbines suited to our size burn distillate ofl and have slightly poorer performance characteristics than comparable light-oilburning diesels. Ebulltent cooling is necessary because the University has a steam heating system and it would be prohibitively expensive to make the modifications needed for heating some bulldings with hot water. There are two advantages to burning residual oil: It is significantly cheaper, and 
Fig. 3.1-3: Electric and Themal Out.puts of Sulzer Engine

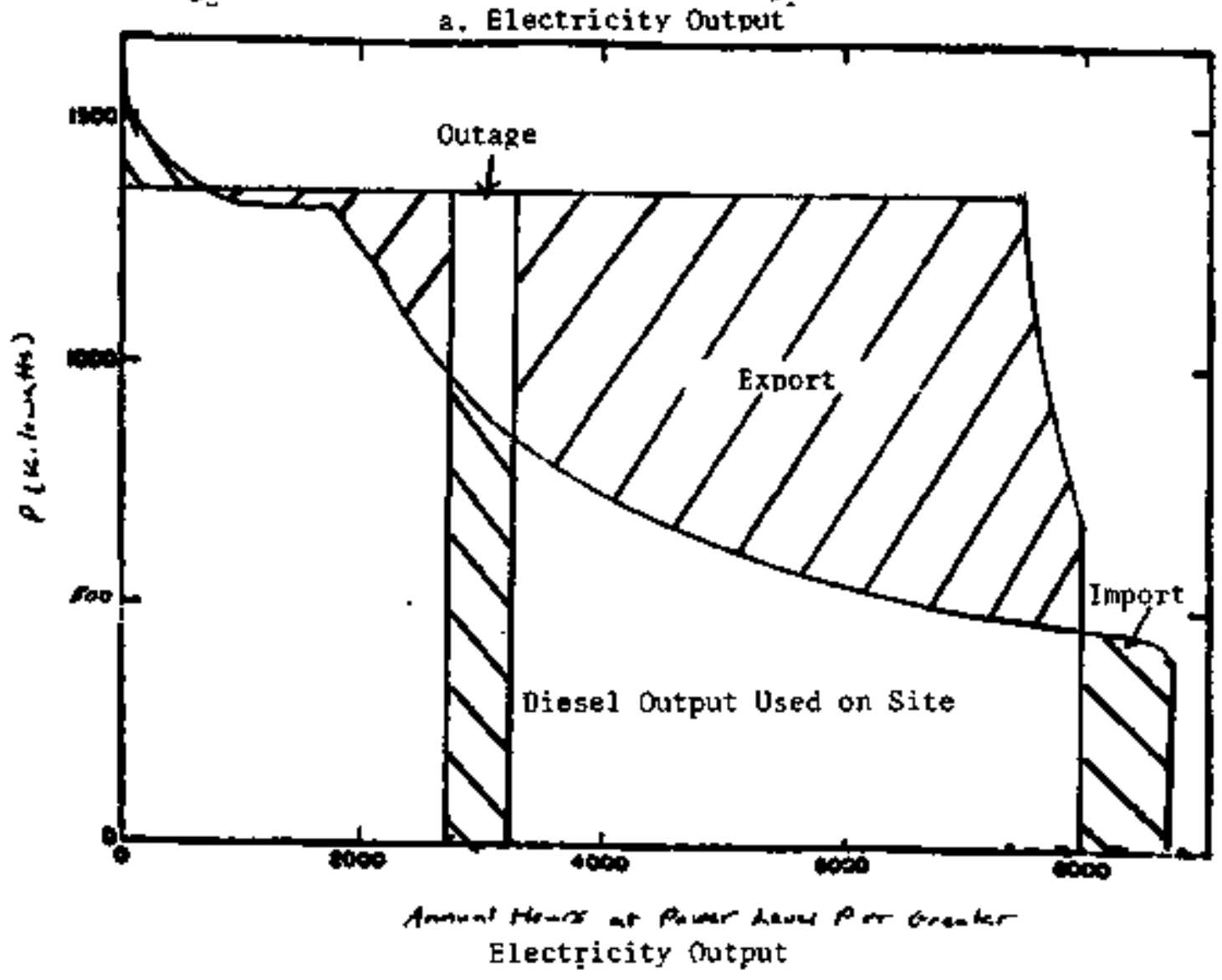

b. Thernagl Output

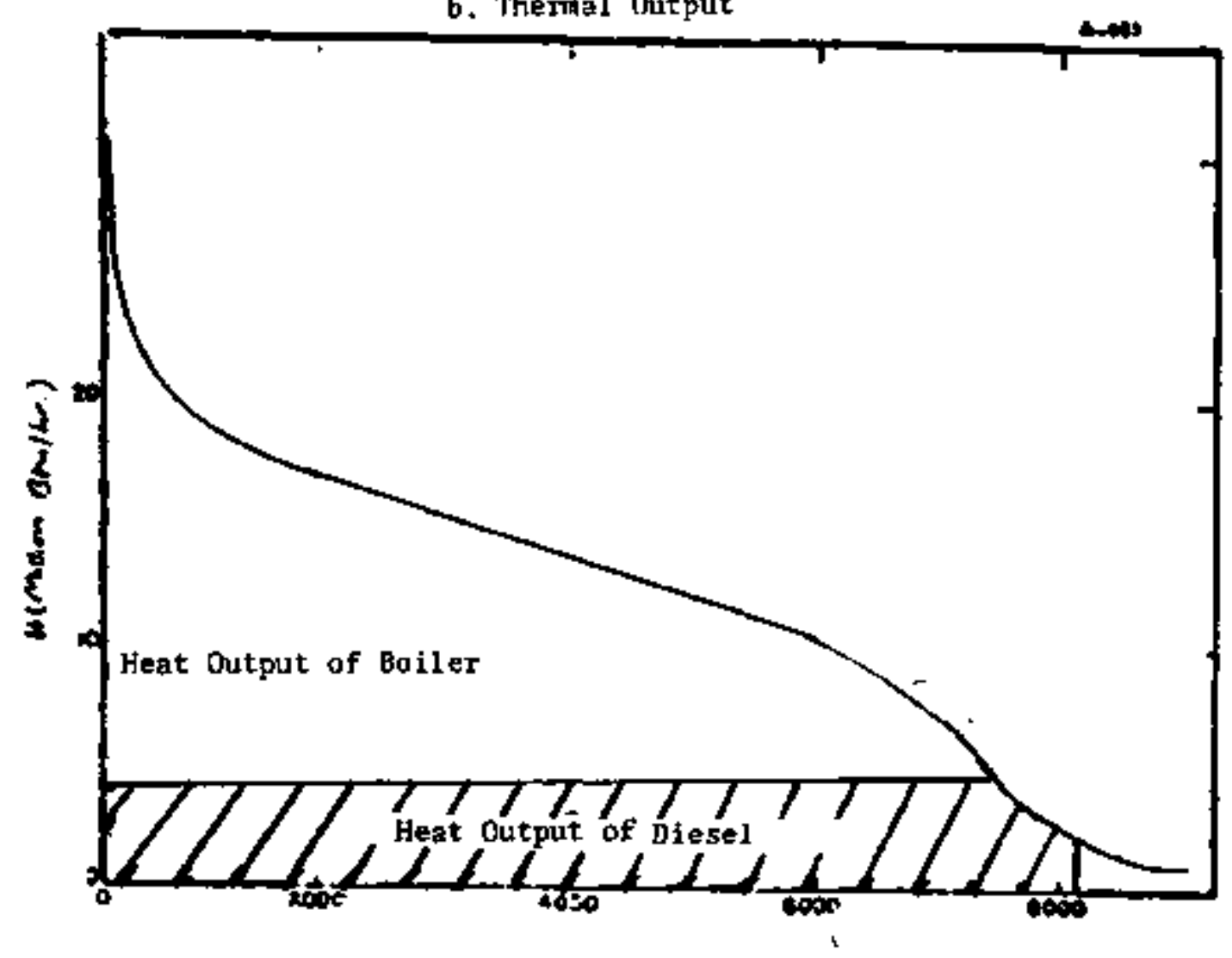


it is in the national and regional intexest not to add to the pressure on the demand for 1 ight oil and gas. Grid-connection obviates the need for multiple engines as we don't have to follow Clark's electrical demand and as we are not considering engines large enough to require extensive variation of heat output. Finally, the size of the generating system is fixed by econonic considerations. While it is profitable to sell excess electricity to the utility, it is not sufficiently proftable under the present terms to finance capacity which is solely for exports. Thus the optimum generator will produce approximately as nuch electricity as will meet clark's peak electrical denand.

In Phase I we made our analysis using a diesel generating systen which met all of the above requirements except for one; the engine burned only distillate oil, not residual oil. Since then we have identified two candidate diesels of the right size which can burn residual oil and be cooled ebulliently. These are a $1400 \mathrm{KW}$ engine made by Sulzer, nodel 8 ASL 25/30, and a $1500 \mathrm{~kW}$ engine made by Cooper Bessimer, Superior model 40-X-l6. The Sulzer engine is normally water cooled, not ebulliently cooled; however, the Sulzer Company assures us that the alterations are minor ones and that they are happy to maintain their standard one-year guarantee. The Superior engine normally burns distillate oil; the manufacturer, Cooper Energy Systems, is wiling to modify the engine to burn residual ofl. They too will maintain their one-year guarantee, with the proviso that the fuel entering the engine be carefully monitored to ensure strict limits on sodium and vanadium in the fuel.

Since both manufacturers are confident that the madifications will not impair the perfomance of the engines and since they will guarantee the engines, we feel that both engines are viable options. Since they offer a significant economic advantage over the distillate-fired engine, we would prefar one of then as the generator for the grid-connected ICES. It is worth noting that, according to Thermo-Electron, both manufacturers have thoroughly competent field service representatives. Sulzer's U.S. service is performed byGolten Marine, Brooklyn, New York, who have worked nany years on residual-burning marine diesels. Superior has their own field service team which also has much experience. 
We chose the Sulzer engine in preference to the Superior for the following reasons. (1) We believe that the burning of residual oil is a more sensjtive modification than the change to ebullient cooling. Sulzer has both Iaboratory and field experience with burning $\$ 6$ oil in that engine. That experience is sumbrized in Appendix 3A. (2) Sulzer places less stringent Iimits on vanadiun and sodtum than Superior. (3) The Sulzer engine gives a slightly better return on investment (see section 4.3). (4) The Sulzer engine is smaller and will be easier to install.

Each of these is a small consideration, but taken together they lead to a clear preference for the Sulzer engine.

\subsection{Update of Conceptual Design}

The conceptual design section of the Phase I report has to be modified to take account of (1) the new choice of diesel engine, (2) the need for a fuel treatment system for 16 oil, and (3) the decision to place the system in a new location.

In Appendix 3B we give a detailed description of the two candidate \#6burning engines, Sulzer and Superior, and compare them with the \#2-burning Fairbanks Morse. The \#6 ail engines differ from the \#2-burning engine described in phase I in requiring a fo fuel treatment system and a separate set of 2 oil storage and day tanks for staxting and stopping. The stean and electrical systens are the same for al1 engines. In Appendix 3C we present details of their performance, including heat balances at $100 \%$ and $50 \%$ loads. Engine performance deteriorates only slightly down to 50s load; it fa11s off rapidly for lower 1oads. Pexformance characteristics at $100 \%$ load are sumarized in Table 3.3-1. Heat and electric outputs of all three engines are similar; however, because $\$ 6$ oil is cheaper and is the fuel now used in the boiler systen, the \#6-burning engines have appreciably lower fuel costs, about $5.5 \mathrm{mills} / \mathrm{kwh}$ less than the $\$ 2$-burning engine.

In Appendix 30 we give specifications and operating characteristics for the fuel treatment system. The system removes sodiun by denulsifying and centrifuging; this also removes most other metals. It then neutralizes the damaging vanadium compounds by combining the vanadium with the magnesium to make magnesitun vanadate, which is not danaging to the ongine at the diesel 
operating temperature. These properties are sumarized in Table 3,3-2.

Table 3.3-1: Performance Characteristics of Three Diesel Engines

\begin{tabular}{|c|c|c|c|}
\hline & $\underline{\text { Sulzer }}$ & Superior & $\begin{array}{l}\text { Fairbanks- } \\
\text { Morse }\end{array}$ \\
\hline Fue 1 & \#6 & 16 & 82 \\
\hline Maximut Electrical Output & $1405 \mathrm{~kW}$ & $1500 \mathrm{KW}$ & $1531 \mathrm{~kW}$ \\
\hline Thermal output & $3.6 \times 10^{6}$ & $5.2 \times 10^{6}$ & $4.0 \times 10^{6}$ Bty \\
\hline Low pressure stean & $1.3 \times 10^{6}$ & $2.5 \times 10^{6}$ & $1.0 \times 10^{6}$ Btu \\
\hline High pressure stear & $2.3 \times 10^{6}$ & $2.7 \times 10^{6}$ & $3.0 \times 10^{6}$ Btu \\
\hline Electric Efficiencies & $38 \%$ & $32 \%$ & $36 \%$ \\
\hline Thermal Efficiencies & $40 \%$ & 498 & 428 \\
\hline Heat Rate & 8970 & 10.700 & 9500 \\
\hline $\begin{array}{l}\text { Incremental Heat Rate with } \\
\text { Heat Credit }\end{array}$ & 6050 & 6150 & 6280 \\
\hline
\end{tabular}

Table 3.3-2: Properties of Fuel Treatment System

\begin{tabular}{|c|c|c|}
\hline Impurity & Soditim (Na) & Vanadium (V) \\
\hline $\begin{array}{c}\text { Impurity content of } \\
\text { Typlcal Fuel }\end{array}$ & $150 \mathrm{ppm}$ & 150 ррг \\
\hline $\begin{array}{l}\text { Impurity Content of Treated } \\
\text { Fuel (for Sulzer engine) }\end{array}$ & $<30$ ppm & $<100 \mathrm{ppm}$ \\
\hline Treatment & $\begin{array}{l}\text { Demulsification } \\
\text { followed by } \\
\text { centrifuging }\end{array}$ & $\begin{array}{l}\text { Formation of harmless } \\
\text { magnesium vanadate }\end{array}$ \\
\hline Treatment Chemical & $\begin{array}{l}\text { Tretolite RI-35 or } \\
\text { Nalco } 9-533 \mathrm{DA}\end{array}$ & Tretolite $\mathbf{K I}-16$ \\
\hline Dosage & -- & $3.2 / 1 \mathrm{~kg} / \mathrm{V}$ \\
\hline
\end{tabular}

Figure 3.3-1 shows a sample layout for the components of the systen using the sulzer engine and including the fuel treatment syster. It is set in a new bullding $60^{\prime} \times 37^{\prime} \times 24^{\prime}$. This figure also shows the location of the building relative to the Goddard Memorial now under construction. The building location and shape is chosen to obtrude as little as possible on the memorial. 


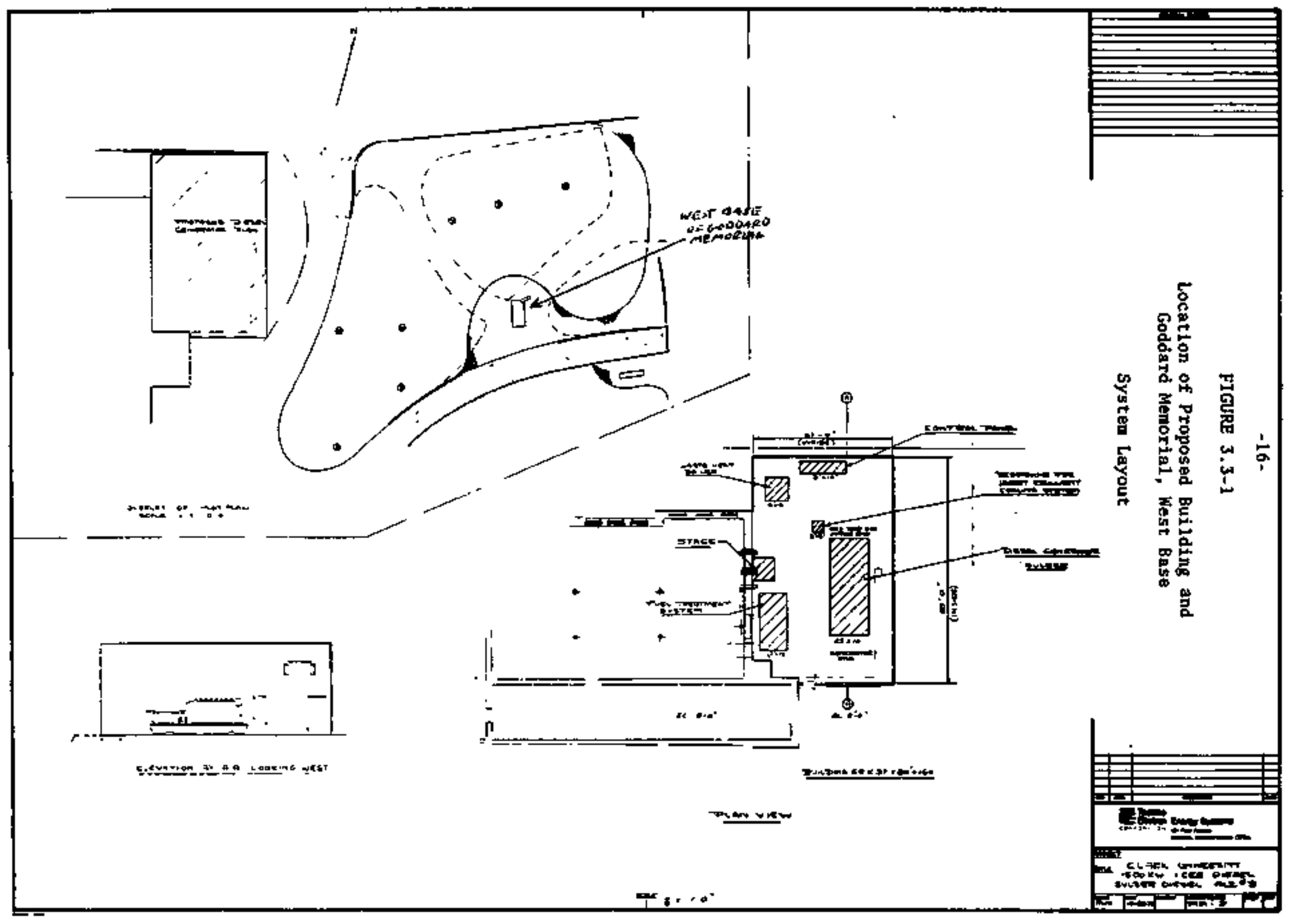




\section{COST ANALYSIS \\ 4.0 Introduction}

There are two substantial changes in the cost analysis of our Phase I report. (1) Capital costs have increased. Because of uncertainty in federally subsidized ftnancing prograns, we take 6\% as a base case interest rate. The combined effect is to raise annual capital charges by $\$ 63,500$. (2) We have identified a suitable \#6-oil-burning engine. The effect of this is to reduce fuel costs by $\$ 56,700$ per year. In addition, our new analysis contains some minor changes. There are additional maintenance costs associated with burning ${ }_{6} 6$ oil; as a result of further monitoring, we find we can run at half power on most summer nights; and we have refined our evaluation of the utility standby charge, Taken together, both major and minor changes give net cash flows similar to those obtained in Phase $I$.

We discuss capital and operating costs in the next two sections. In section 4.3 we compare the ICES with the conventional system and show that the internal rate of return is about 15\%: We also discuss the sensitivity of the analysis to our assumptions. Finally, in section 4.4 we discuss other features of the ICES which make it an attractive investment.

\subsection{Capital Costs}

Capital cost sunuaxies for three systems, the Sulzer $1405 \mathrm{KN}$ engine, the Superior $1500 \mathrm{KW}$ engine, and the Fairbanks-Morse $1531 \mathrm{KN}$ engine, are shown in Table 4,1-1. Detailed cost breakdowns appear in Appendix 4A. The total capital cost for our selected systen, the Sulter $1405 \mathrm{KW}$ engine, is $\$ 1,380,000$, compared to the $\$ \$ 20,000$ Phase $I$ estimate of cost for the Fairbanks-Morse 1531 KW systen. An analysis of the cost increase follows: (1) Clark's tecision to use a new building for the plant adds about $\$ 200,000$ to the cost; (2) a fuel treatment systen for 16 oil adds about $\$ 100,000$ to the cost; (3) a more expensive engine adds about $\$ 100,000$ to the cost; and (4) riscellaneous extra equipment and engineering costs not considered in Phase I add about $\$ 150,000$ to the estimate. Only (1) and (4) apply to the Fairbanks -Morse engine, so its revised capital cost is $\$ 1,190,000$. Table 4.1-1 also shows the yearly finance costs assuming level payments on a 20-year note at both three percent and six percent interest. The 
TABLE $4.1-1$

Capital Cost Sumnary

Sulzer Superior Fairbanks Morse
(Costs $/ \$ 1000)$

Equipment and Mechanical

Work

869

807

681

Civil Work

255

255

255

Electrical Work

(not including grid connection)

51

51

51

Engineering Cost

207

207

200

Total Cost to Clark

1382

1320

1187

Grid Connection Equipment

40

40

40

Monitoring Equipaent

35 .

35

35

Engineering

15

15

15

Cost to ERDA

90

90

90

Claxk Yearly Paynents

at 6t Level Loan

118

113

102 
yearly costs for the Sulzer would be $\$ 91,000 / y \mathrm{r}$ and $\$ 118,000 / \mathrm{yr}$, respectively. The Fairbanks-Morse costs would be $\$ 78,000$ or $\$ 101,000$. Going from $6 \$$ to $7 \$$ financing would piace the Sulzer capital costs at $\$ 128,000 /$ year.

In the remainder of Phase II we will refine these cost estimates. We will also evaluate the escalation of the costs through the construction period.

\subsection{Fuel and Maintenance Costs}

Fuel costs with heat credit for the three engines are evaluated in Table 3.3-1 and Appendix 3C. These are summarized in Table 4.2-1:

Table 4.2-1: Fuel cost and heat credit

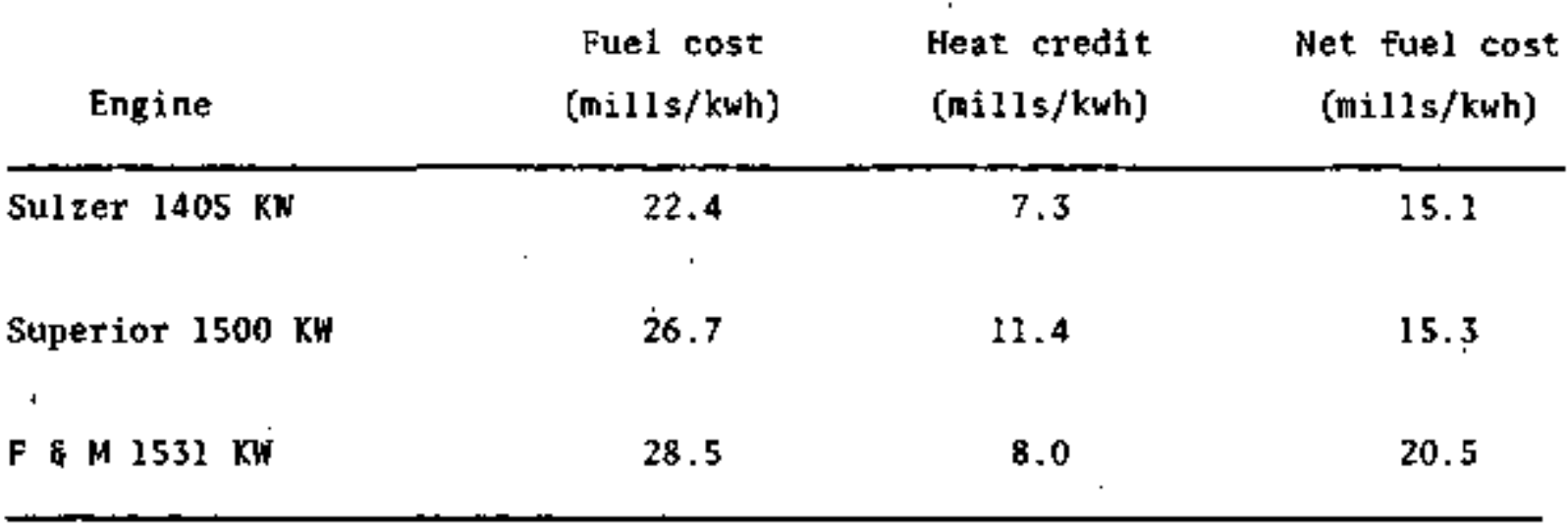

Note the much greater net fuel cost of the Fairbanks-Horse engine, because it burns more expensive 2 oil.

We constructed Table 4.2-1 assuming that the price of \#6 oil to Clark would be $\$ 2.50 / 10^{6} \mathrm{Btu}$, and the price of $\# 2$ oil would be $\$ 3.00 / 10^{6} \mathrm{Btu}$. The present prices are $\$ 2.20 / 10^{6}$ Btu and $\$ 2.65 / 10^{6}$ Bțu, respectively. The increase is based on the assumption that oil prices will show the same seasonal change this year as last.

Maintenance costs for the three engines are summarized in Table 4,2-2. 
Table 4.2-2: Maintenance Costs

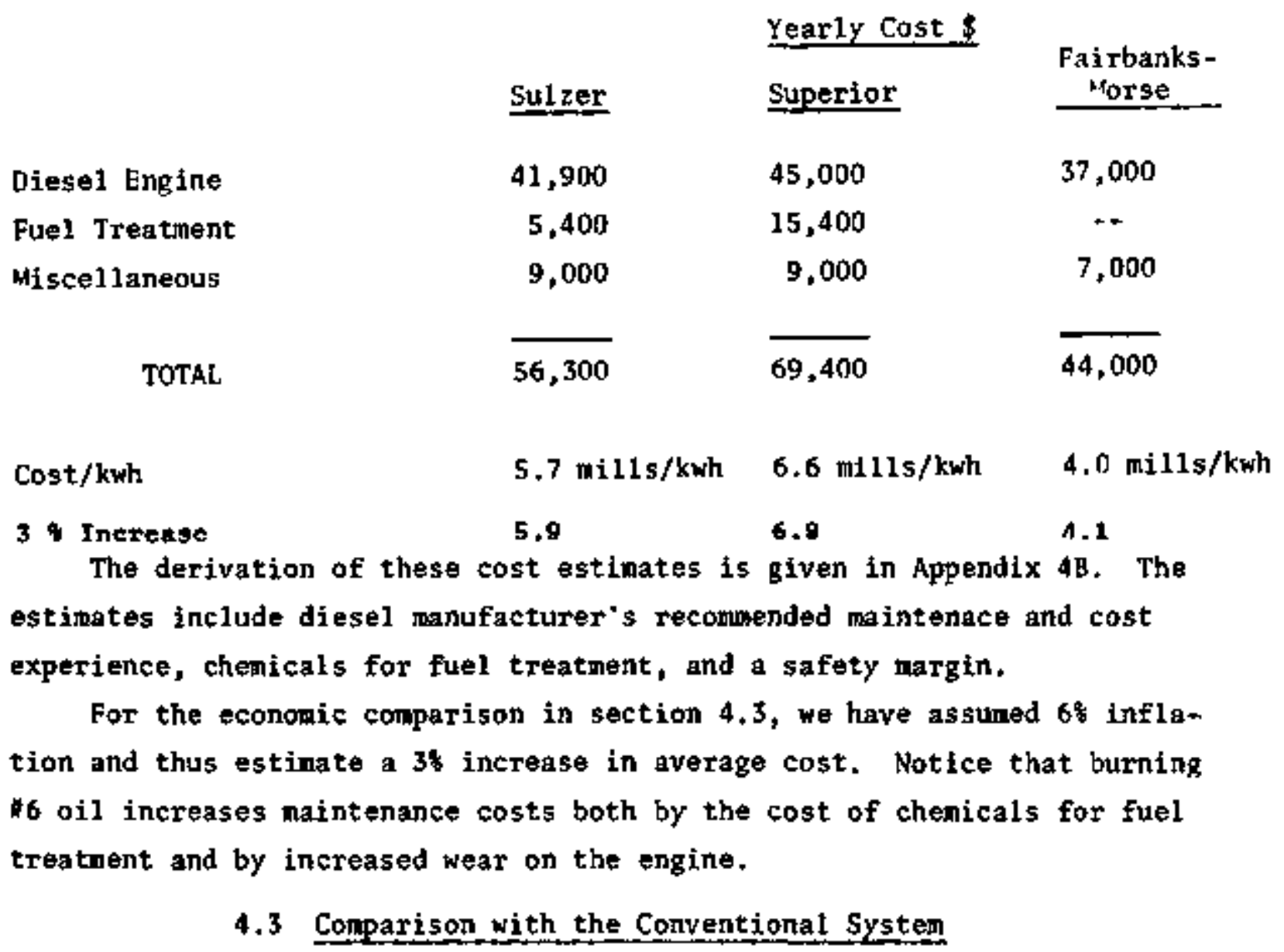

In Table 4.3-1 we list the base-case assumptions we have made about costs which we will use to compare the grid-connected ICES with the conventional system. We as suned that the ICES was completed today at the capital cost of section 4.1, that fuel prices for the coming year will show the same seasonal variation as last year, and that all costs will escalate at $6 \% / y \mathrm{r}$. We show later in this section that the results do not depend drastically on the assumptions.

We list in Table 4.3-2 the energy output of the ICES used at Clark and sold to the utility. These numbers are taken from the energy outputs described in section 3,1. There is one conplication, however; because the standby terms require only that Clark pay at least a minimum charge each nonth, Clark has available a certain anount of "free" electricity, that is, 
Table 4.3-1: 3ase case assumptions

\begin{tabular}{|c|c|}
\hline Variable & Value \\
\hline Rate of inflation & $68 / y \mathrm{r}$ \\
\hline \multicolumn{2}{|l|}{ Price of fuel (anticipated) } \\
\hline$\# 2$ oil & $\$ 3,00 /$ MBtu \\
\hline \#6 oil & $\$ 2,50 / \mathrm{MBtu}$ \\
\hline \multicolumn{2}{|l|}{ Prices of electricity (anticipated) } \\
\hline Purchased by Clark & $4.45 \$ / \mathrm{kwh}$ \\
\hline Sold by Clark, weekdays 7 A.M. - 11 P.M. & $2,60 k / \mathrm{kwh}$ \\
\hline Sold by Clark, other & $2,15 \downarrow / k w h$ \\
\hline Standby Minimum & $\$ 32,000 / y x$ \\
\hline Retail rate stmucture multiplier & 1.2 \\
\hline P1ant lifetime & 20 years \\
\hline Clark electric demand & $6.9 \times 10^{6} \mathrm{kwh} / \mathrm{yr}$ \\
\hline Conventional boiler efficiency & 758 \\
\hline
\end{tabular}

electricity which it has already paid for by paying the minimum. That electricity can have two values; one is a value equal to the present retail price of electricity when it replaces electricity that Clark would purchase anyway, and the other Is a value equal to the operating costs of the ICES when it replaces ICES-generated electricity. Our estimates for each quantity of electricity are also shown in Table 4.3-2. We expect that there will be approximately .55 $\times 10^{6} \mathrm{kwh}$ of fred electricity. About. $3 \times 10^{6} \mathrm{kwh}$ will replace electricity that Clark would purchase anyway and about .25 $\times 10^{6} \mathrm{kwh} \mathrm{will}$ substitute for ICES generated electricity. The ICES will generate in all about $10.4 \times 10^{6} \mathrm{kwh}$ of which $4.2 \times 10^{6} \mathrm{kwh}$ will be sold to the utility. We are now ready to compare the costs of the ICES with the costs of the conventional systen. The comparison is made in Table 4.3-3. Under the base assumptions, the sulzer $1405 \mathrm{KW}$ engine has a first-year operating savings of about $\$ 148,000 / y T$, and net savings after payment of financing costs of about $\$ 30,000 / y x$. By the tenth year we project these savings to be approxinately $\$ 270,000$ and $\$ 150,000$, respectively. The projected basecase yearly savings for the three engines are shown in Figure 4.3-1. 
Table 4.3-2: Electricity and Themal outputs

\section{ELECTRICITY}

1. Clark total demand

2. Clark denand supplied by diesel

3. Claxk denand supplied by purchases up to minimam standby payment
a. Minimum purchases replacing retail purchase
b. Minimum purchases replacing ICES generation

$6.9 \times 10^{6} \mathrm{kwh}$

6.2

.55

.25

.30

4. Clark demand supplied by additional purchases

.15

5. Diesel-produced energy sold to utility

4.2

6. Total production by diesel

7. Maximum possible production by diesel

8. Capacity factor

9. Outages for maintenance and certain summer nights

10. Operation at de-rated power level (average 65\% full load)

10.4

12.5

$83 \%$

86

125

HEAT

11. Clark total demand

12. Clark demand supplied by diesel FUEL SAYTNCS

13. Savings at Clark plus savings at utility due to reduced Reneration

$3 \times 10^{10}$ Btu

It is clear that the residual-oil-burning engines are preferable to the distillate-oil-burning engine; the sulzer engine has a slight lead over the Superior.

We have examined the sensitivity of the projected savings to the values of our base case parameters. In Table 4,3-4 we list the key paraneters and the sample variations we have used to test the sensitivity of the savings. Figure 4.3-2 shows the variation of the Sulzer engine savings with each of the changes. The total variation is taken to be the square root of the sum of the squares of each tndividual variation. The savings are always 
Table $4.3-3$

FINANCIAL ANALYSIS OF THE SYSTEM

Sulzer Superior $\quad \begin{aligned} & \text { Fairbanks- } \\ & \text { Morse }\end{aligned}$

A. DIESEL PLANT

1. Capttal cost

2. Fuel cost

3. Maintenance costs

4. Gross operating costs

5. Heat credit

6. Standby charge

7. Purchases over standby minimun

8. Operating costs (in units of $\$ 1,000$ )

118

233

61

294

76

32

7

257
113

299

76

375

128

32

7

286
102

297

43

340

85

32

7

296

B. UTTLITY PRICE ARRANGEMENTS

9. Price of electricity sold to Clark under conventiongl systên

10. Credit for electricity sold by Clark to utility under proposed systen

11. Operating credits

97
404

147

13. Net savings

D. FUTURE BENEFITS

14. Yearly benefit in fifth year 15. Yearly benefit in tenth year

16. Integrated 10-year benefits

E. PAYBACK

17. Years to pay back laan if all savings used to reduce debt

18. Interna1 rate of return
9.2 years

$15 \%$
115

422

97

404

$\begin{array}{rr}138 & 97 \\ 25 & -5\end{array}$

30

14275

$800 \quad 350$ 


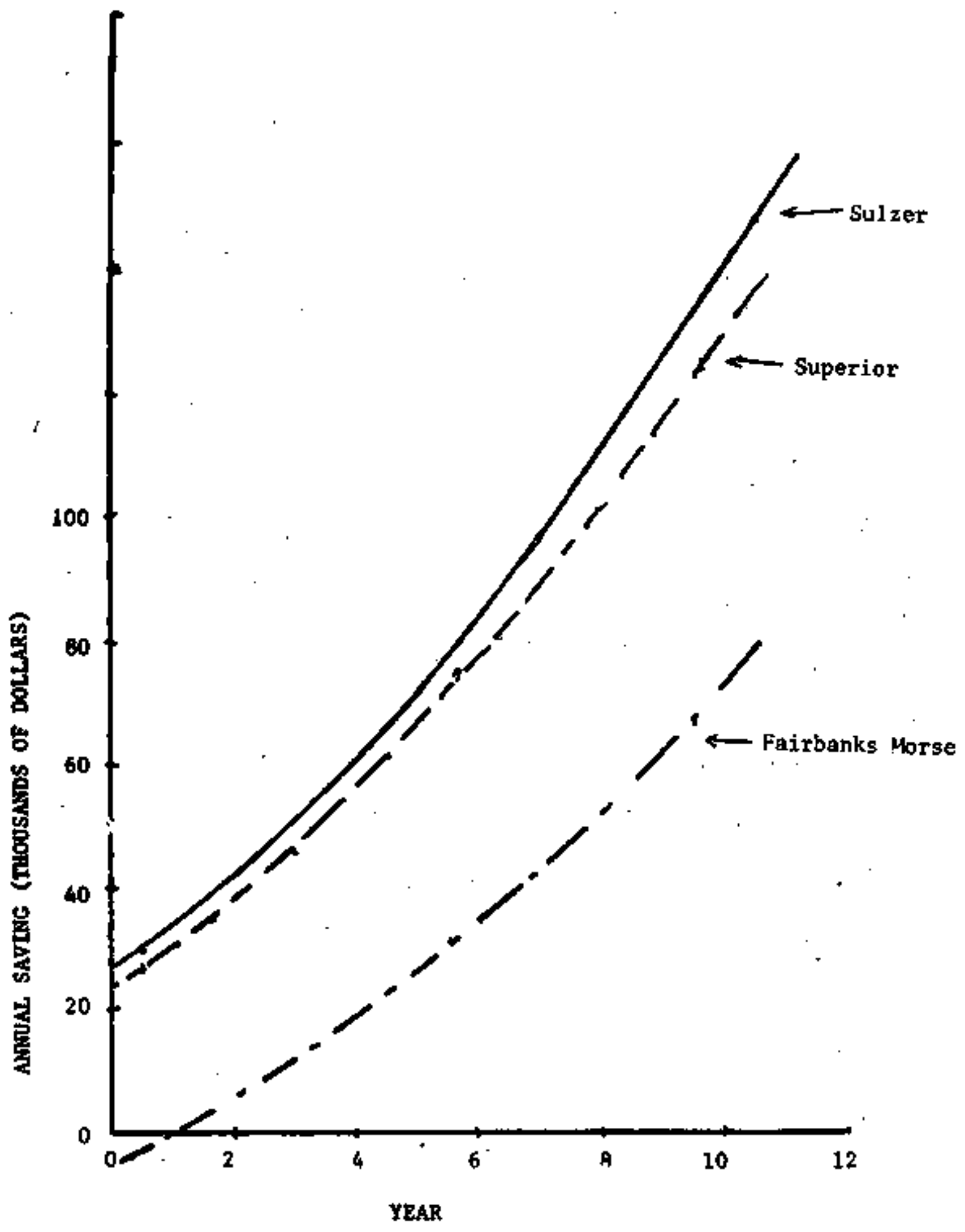

Figure 4.3-1

Projected Base-Case Yearly Savings 
$-25-$

TABLE $4,3-4$

Key Paraneters for Sensitivity Analysis

Key Parameters

Efficiency of Clark Botler

Interest Rate on Loan

Retail Electricity Rate Hultiplier

Rate of Fuel Price Escalation

Additional Credit for Exports

Underestimate of Capital Costs

Inflation Rate
Base Value

.75

$.06 / y$

1.2

$.06 / y 5$

0

0

$.06 / y r$
Variation Tested

.85
$.03-.07 / y r$
1.35
(f1at rate is 1.5)
$0.0-.12 / y \mathrm{r}$
$.3 \$ / \mathrm{kwh}$
$\$ 200.000$
$.03-.09 / \mathrm{yr}$




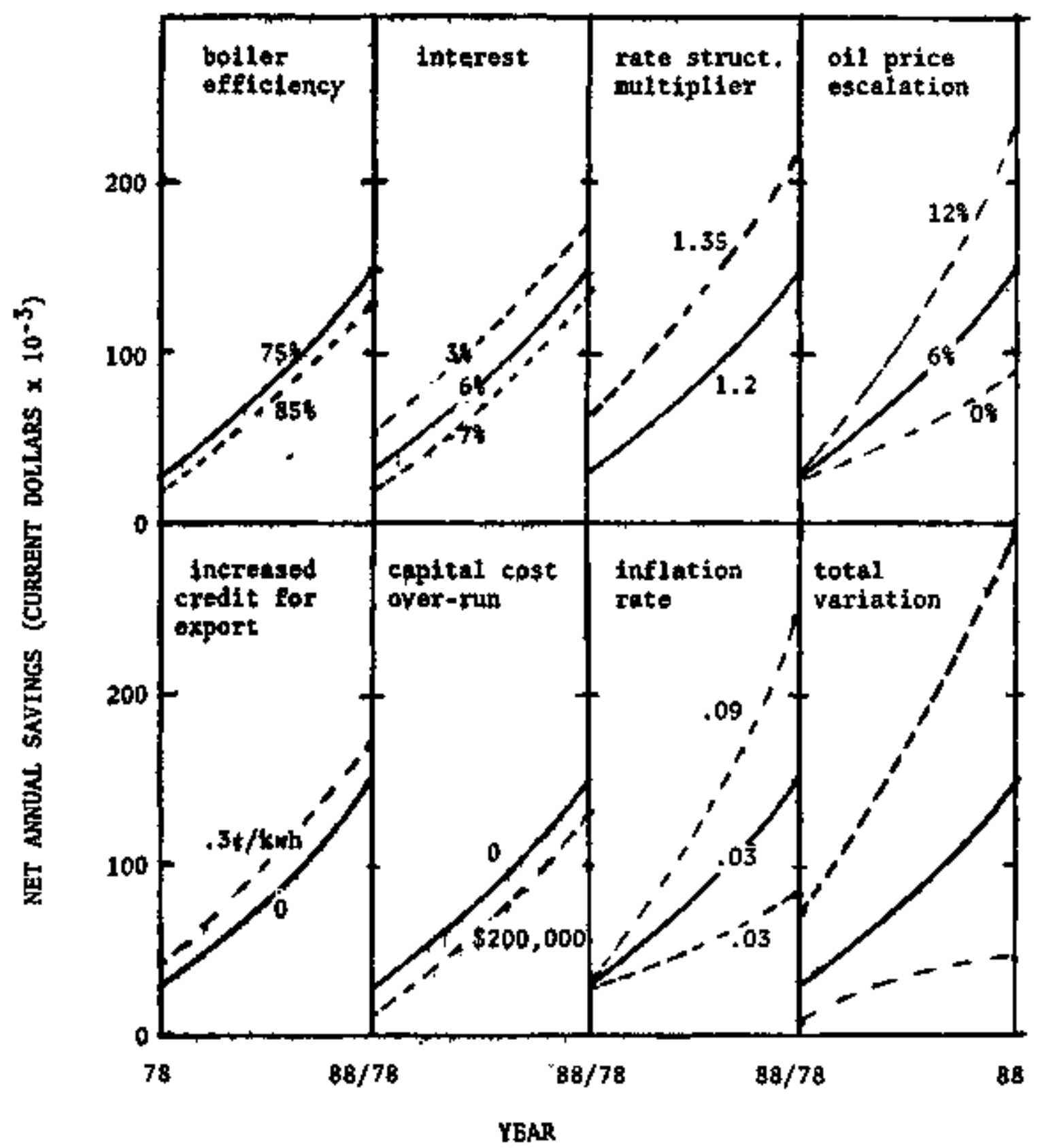

Pig. 4.3-2: Sensitivity of savings for the Sulzer engine burning "6 ofl. Base case is shown as soltd line, variation by dotted line. The variation used is defined in Table 4,3-4, 
positive even for the total variation, so there is little risk to be expected fron the variation of those parameters. Note that flattening of the retail electricity rate seructure could cause a big increase in the savings.

\subsection{Evaluation of the Investment}

The anticipated 15 internal rate of return with the regsonsble assurance of positive net savings is enough to nake the grid-connected ICES an attractive investment for Clark. In addition, as polnted out by the University business officer, $t$. Landry, the Investment in the ICES is a hedge against the inflation of energy costs (see his letter in Appendix 1A). If about half of the electricity. generation costs are fixed as capital costs, only the remaining half are subject to inflation. Thus the costs using the ICES will rise much more slowly than costs for the conventional system as oil prices go up. Of course, costs would decline less rapidly if oil prices dropped, but we consider that much less likely. Furthermore, by generating most of its electricity, the University would be almost completely insulated from unfavorable changes in electricity rates. It is certain that electricity rates will change in the next year, as the DPU has required utilities to introduce time-of-day rates. It is not certain that the changes will be unfavorable to Clark, but it is likely. The University now benefits from sharply declining block rates (see Appendix 2B), and there is both state and federal pressure for flattening rate structures. Furthermore, the Universtty does not have much flexibility for shifting nore electric use to the nightine and so it could be hurt by very high peak rates.

Thus we consider the ICES an attractive investment on two grounds. It offers a decent rate of return with only nodest risk, and it helps protect the University from potential unfavorable changes in energy prices. Along with these benefits Clark would benefit significantly fron being a demonstration site. The demonstration would give Clark national visibility and would give a najor boost to our research and teaching in energy studies. 
$-28-$

APPENDIX IA

Letter from lawrence landry, Vice President of Rosiness and Finance and Treasurer 
Oark Ummerity WOACESTEA, MESSACHUSETTS D1610

OLFICE OF THE TREASURER

617.793 .7443

4 November 1977

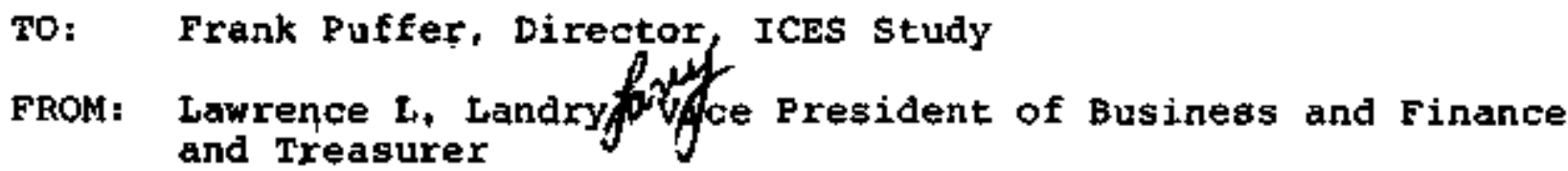

I would like to summarize my findings to date as to the financial desirability of the proposed ICES to service the clark Iniversity campus. The econonic analysis can be stated in several ways, depending upon the assumptions one wishes to use about future operating and final capital costs for constructing the Ices. For my purposes; I am assuming a $\$ 1,400,000$ capital investment will be required and that priof to debt service payments, first year savinga in operating costs will be $\$ 148,000$. Assuming a 6 percent inflation factor, the savings will rise to $\$ 299,000$ by the fifth year and $\$ 269,000$ by the tenth year. Overall the analysis indicates a nine to ten year payback period. These numbers are sufficiently attractive to warrant an investment by clark.

As you know, the Executive and Finance Comulttee reviewed the preliminary findings last sumer and felt that the investment was attractive enough to continue our stuay, Recently I have shared our updated numbers from the economic analysis with charles Sanders, Chalrman of the Trustees' Finance committee. He shares my enthusiasm for proceeding with the project. We would expect that if the findings to date are verified in the course of our Phase II study that the Trustees would vote to construct the ICEs.

Perhaps it would be helpful for you and other members of the research team to understand the reasons for our enthusiasm. Aside from the initial cost savings, our interest in the cogeneration plant has a direct relationship to the overall financial situation at the University. The basic problem in Higher Education is that the costs per student have been rising at a greater rate than the income per student. In other words, a University is much more vulnerable to inflation than an enterprise that has productivity increases through the use of new technology. Because of this reason as well as our labor intensity, clark has developed the philosophy of making prudent investments which at least result in fixing our costs at current levels. 
The cogeneration project is an excellent example of the type of investment which can help further control costs. To date, the University has an outstanding record in the field of energy management. For example, since the first oil embargo we have reduced electrical and heating consumption by 35 percent. However, costs continue to escalate. An added attraction of the proposed plant is that it would insulate a substential portion of the University's energy costs from inflation. Currently 100 percent of our energy bill is subject to inflation; with cogeneration, about 50 percent of energy costs would be affected by inflation. Furthermore, and I expect nuck more significant, is the fact that the project will provide a perfect defense against electrical cost increases that would result from alteration in the current price structure of electricity. Under the existing price structure, the unit cost of electricity declines as consumption increases. However, we seem to be moving toward a "flat rate" or "peak load" formula for pricing electrical power. lluse or similar changes would increase the unit cost of electricity to clark. However, with a cogeneration plant, the University would be less vulnerabIe to these cost shifts.

Another consideration in evaluation of an investment is the ICES is that unlike industrial concerns, the University does not have alternative investments that could yield the same benefit. This fact as well as the opportunity to finance completely through debt makes the investment that much more attractive. In connection with financing the plant, I am guite aptimistic that funds can be raised at a cost not to exceed 7 percent. Although our first preference for financing would be from federal programs, we are also developing a fallback position in case federal funds are not available. We are pursuing two alternative routes of financing and are receiving advice from an investment banker; namely, Adams, Harkness Hill. Mr. Marsom Pratt from this firm has worked previously with the University and assisted us in placing a tax-exempt bond issue in August 1977 for $\$ 2,200,000$ at a net interest cost of 5 percent through the Health Educational Facilities Authority (HEFA).

Alternative to federal financing is to use tax exempts through the HEFA Authority. I have discussed this option with Samuel C. Brown, Executive Director of the Authority and he is optimistic about our possibjlities for financing the plant. Accordingly, he has asked Marșom Pratt to work with us in evaluating our study and developing a tax-exempt package.

A further alternative to a tax-exempt bond issue, we are also exploring financing through a leveraged lease. Recently, Harvard University successfully financed a generation plant by using this method. Adans, Harkness \& Hill is a highly regarded fim with many contacts and $I$ believe that they will successfully finance the ICES plant for the University. 
Although I expect that one of the above-mentioned financing routes will eventualiy be approved by the clark Trustees, $t$ should point out that the Board could elect to borrow from endowment funds and in that respect provide self-financing. The final decision on financing, however, will be made in conjunction with the final plans for the plant. In other words, once we have fixed a time schedule and capital costs, the Trustees can then commit the University to a garticular financing package.

\section{ILL/pa}


APPENDIX 2A

\section{Letters from:}

Mary Joann Woods Reedy, Assistant Attorney General, Division of Public Charities

D.fchard W. Mirick, Mirick, D'Conne11, DeMallie and Lougee, Counselors at Law

Ronald W. Plutnicki, Consumer Service: Gusultant, New England Power Service Co., NEES

Edmund G. Benoit, Chief, Air nuality Control Section. 


\section{THE COMMONWEALTH OF MASSACHUSETTS \\ DEPARTMENT OF THE ATTORNEY GENERAL \\ JOHN W, ME ODRMACK UTATE OFPICE BUILOINO

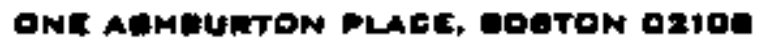

October 21, 1977

Richard W. Merick

Merick, O'Connell, DeMallie and Lougee

1700 Mechanics National Tower

Worcester, MA 01608

Dear Mr. Merick:

You have requested the opinion of this office on the legal power of Clark University to engage in the construction and operati<n of an integrated community energy system (ICES).

Upcn review of your letter and the attached charter and feasibility study it is my conclusion that the primary purposes of the project will advance the charitable purposes of the University. The distribution of excess energy to a public utility would be incidental to the primary purposes, and would not atfect the charitable status of the University. Conklin v. John Howard Industrial Home, 224 Mass., 222 (1916): McKay v. Horgan Hemorial Goodwill Industries, 272 Mass. 121 (1930).
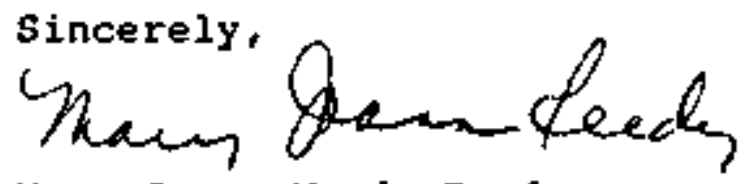

MJWR/kah

Mary Joann Woods Reedy Assistant Attorney General Division of Public Charities 
MjRick, O'Connell. Demaleje \& Lougee

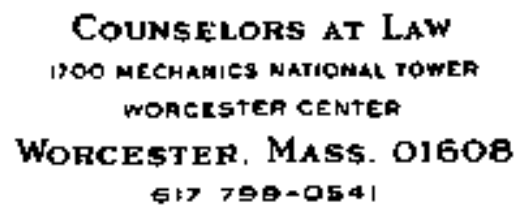

November 4,1977

Lawrence L. Landry, Vice President for

Business and Finance

Clark University

950 Main Street

Worcester, Masgachusetts 01610

Dear Mr. Landry:

I suggegted to you sume time ago that if the University proceded with construction and operation of a grid-connected integrated community energy system, and sold any excess electricity to the local public utility, it might be argued that the University as an eleeymosynary institution did not have the legal power to manufacture and sell electricity.

I am happy to report that discussion and correspondence with the Division of Public Charities of the Department of the Attorney General of the Commonwealth of Massachusetts has resulted in a response indicating that the project would not affect the charitable status of the University. I am attaching a copy of the letter from Assistant Attorney General Reedy.

The Division of Public Charities is the agency which represents the public interest in matters involving the charitable status of eleemosymary institutions. In view of her letter I do not anticipate any questions from any other state or local government source as to the University's legal power to proceed with the project as planned.

Very trity yours,

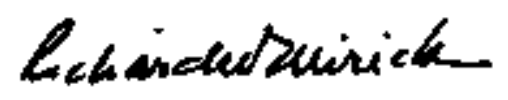

Richard W. Mirick

$\mathrm{RWM} / \mathrm{pjb}$

Enc. 
Dear Dr. Puffer:

Clark-LOE Deranstration Progran of a Grid-Connected Integrated Commity Energy (Cogeneration) Systern

I have been advised of your recent meeting with Clark's Board of Trustees concerning the status of the subject program. Apparently, sone of the nembers of the Board are unsure of Massachusetts Electric Corpany's position relative to its support of Clark's proposed Cogeneration project.

Let me assure you that my Company's position toward this project has not changed since we agreed to become an active participant in your proposed program to DOE back in Novenber of 1976. We have expended much tine and effort in the development of the Phase I Report, as weIl as the soon to be completed Phase II Report; and, offer the same continued erfort through the renaining Phases of work toward a successful completion of the demonstration facility.

It is important to note that our parent company, New England Electric System, has comnitted itself to the national energy conservation program. This has been deronstrated by undertaking various studies to evaluate the long range . benefits of energy conservation programs. One such effort is our Solar Water Heating Experiment. This demonstration program was designed to test the suitability of solar water heater systems to help meet the energy needs of New England and their possible future integration with utility operations. Cogeneration of heat and electricity at an industrial or institutional site offers a great potential for energy conservation through improved overall efficiency.

However, many econonic, technical and institutional factors will inpact the future of cogeneration. These factors must be studied and carefully evaluated before the cost/benefit ratio of the cogeneration potential can be determined. 
In order to properly evaluate these factors, it is essential that my Company have some experimental installations in our service area to accumulate valuable operating information. We have recently cormleted a survey, designed to essess the potential of cogeneration with a further attempt to identify a class of cogeneration custoners.

As a member of the Task Force, we have benefited greatly from the input of the other members. We have used this input in our work to develop a policy and cogeneration rate. The information gained in the following phases of work would be most valuable in assessing the cogeneration potential.

We are now studying the long range potential economic benefits of the Cozeneration capacity. The value of this cogeneration capacity will be greatly affected by its availability, its fuel economics, and the manner in which it is dispatched. The Clark Project will be valuable in terals of the information provided by the operating experience of the facility.

We are hopeful that the Clark Cogeneration Demonstration Progran will proceed on schedule; and, we continue to support its successful completion.

Very truly yours,

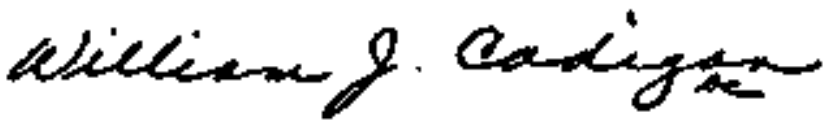




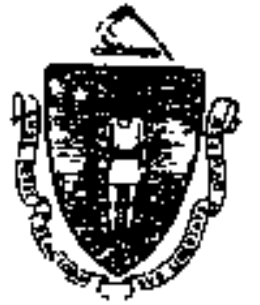

Tet. (1577) $7 p b+5872$

November 4, 1977

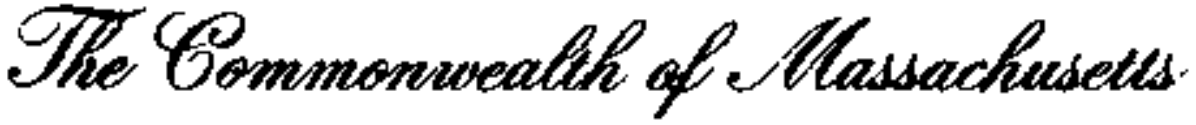

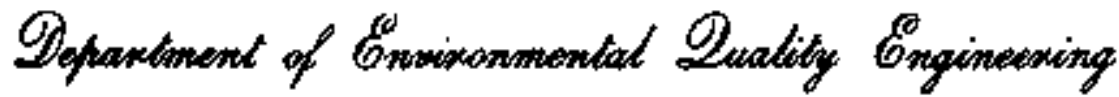

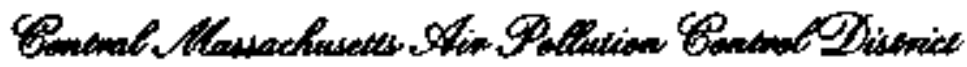
rowathon

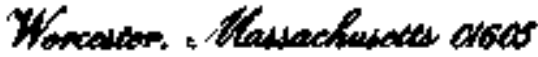

Mr. Lawrence Landry

Vice President of Finance

Clark University

950 main Street

Horcester, Massachusetts 01610

\section{Dear Sir:}

On November 3, 1977. I met wi th Mr. Robert Caiazzo, student, at clark University, regarding the proposed Inter Connected Energy System (ICES) for clark University, 950 Haln street, Worcester, Massachusetts.

As was explained to Mr. Caiazzo, the Worcester area is non-attaintent for total suspended partlculstes, oxidants, and carbon-monoxide. The recently enacted Clean A1r Act of 1977 specifically addressed the problems for non-attal nment regions. In addition, the Act requl res actions to be taken to assure deterioration of tir quallty in clean areas will not occur. It is not yet certain whether this project would have to undergo the review procedures associated with the non-attainment or PSD (Prevention of Significant Deterioration), grovisions of this Act.

It is antitipated that many of the questions surrounding applicabilt ty of the Act to this project wII be resolved shortly.

It is expected that most issues of concern to this offlce would be addressed during the design stage. ThIs would inelude issues such as alr quality monitoring requi rements, stack testing, modeling, submittal for approval of spectfic plans and specifications and possibly subjects suck as growth analysis and emission offsets.

As 1 have stated in the past, this office supports the purpose of this project and will continue to provide informatlon and guidance in air quality matters.

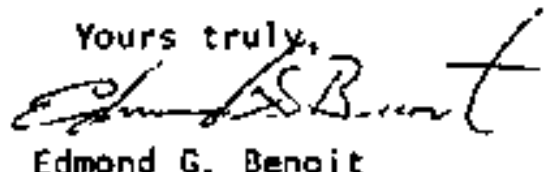

Edmond G. Benoit

Chlef, Atr Quotity Control Section

$E G B: m 1 k$

cc: Harry Schwartz 
$-38-$

APPENMIX 2B

Present Retail Electricity Rate and Standby Terms 
New England Power Service Compeny 20 Turnodke Ploed

Wesibordugh, Massachusells 01581

Tel $\{617) 366-9011$

January 25,1978

Dr. Robert L, Goble

Physics Department

Clark University

950 Main Street

Worcester, MA 01611

Subject: Clark-DOE, Demonstration of a Grid-Connected Integrated Community Energy System

Dear Dr, Goble:

In order to comply with the Department of Energy's request, as stated in its letter of December 15, 1977, I am enclosing herewith a preliminary draft of a Purchase and Sale Agreement for the interchange of electric energy between Massachusetts Electric Company and Clerk University. The draft has not been reviewed by our Legal Department at this time. Therefore, in providing it to you, we intend only to indicate the type of provisions which we would expect to include in a contractual agreement between us. Out of necessity, these provisions are subject to change. Further, it should be understood that it may be necessary to include additional provisions in any contract between us. As soon as our attorneys have completed their review, we will forward to you a copy of the Company's final proposed form of agreement for your review.

Further, you are woll aware of our efforts and attempts to formulate a Cogeneration Policy and Rate; but, at this time, we are not ready to file a cogeneration document with the Massachusetts Department of Public Utilities (M.D.P.U.). When our Cogeneration Policy and Rate' have been finalized, accepted and approved by M.D.P.U., then the Rate will be made available to Clark as gn alternate purchase price schedule to that presented in paragraph 6 (b) of the Agreenent.

I must remind you that any proposed agreement that Massachusetts Electric Company would offer to Clark must be approved by M.D.P.U. before the agreement may be executed. If you have any questions, please contact ne.

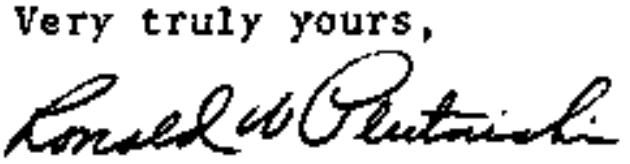

Ronald W. Plutnickt, P.E. Consumer Services Consultant 
PRELIMINARY DRAFT CONTRACT

BETWEEN

\section{CLARK UNIVERSITY AND MASSACHUSETTS ELECTRIC COMPANY}

AGREEMENT dated as of and made by clark

University (Clark), a: Massachusetts university of higher education and Massachusetto Electric Company (Masselec) a Massachusetts Corporation engaged in the retail sale of electricity.

\section{Scope of Agreement}

Clark will generate electricity as a by-product of its cogeneration plant. The mafority of this electric energy will be used to satisfy Clark's requirements. Since the cogeneration plant has been designed with an electrical output greater than Clark's present and projected requirements, clark seeks to sell its excess electric energy from the cogeiteration plant.

Masselec is willing to absorb (in whatever amount) the excess electricity so generated, at the cogeneration plant, into its system whenever this generation is available. Masselec is also willing to provide backup service, lin an amount to be identified) whenever the cogeneration plant cannot meet clars.'s electrical requirements.

The parties of this agreement hereby set dow the terms whereunder they will provicle for an interchange of electric enerf.

2. Sale of Electricity

(a) Clark agrees to sell and Masrelec agrees to buy all excess electricity (over and above clark's requirements) that is generated at Clark's cogeneration plant at the times and under the terms of paragraph 4 of this agreement.

Masselec agrees to sell arid clark aprees to buy all electricity needed to meet Clark's tlectrichl requirements when the cogeneration -40 - 
plant is unable to meet Clark's requirements, under the terms of paragraph 4 of this agreement.

3. Effective Date and Term

The term of this contract shall commence upon the Commercial Operation date of Clark's cogeneration plant and the interconnection with Masselec's gystem, in such a manner as will allow delivery to be made to Masselec, and shall continue until terminated by either party giving to the other 5ix (6) months written notice specifying the date of termination, such date of termination to be not earlier than twenty (20) years after the aforesaid date of commenceinent.

4. Terms of Sale

Clark will operate its cogeneration syotem so as to meet the thermal and electrical requirements of the university complex. Clark'g excesg eleotricity may be delivered to Masselec at any time each day, and such electricity will be purchased by Masselec at the price stipulated in paragraph 5 (a) herein. Masselec will provide ciark with electric service during those times when the clark cogeneration plant cannot meet the university's total requirements, at a price stipulated in paragraph 6 (b) herein.

Clark will arrange its maintenance program to preclude the possibility of the cogeneration system being out of service during the following months of the year: December, January, February, June, July and August.

5. Delivery

Electricty shall be delivered at the interconnection potint between the parties' facilities in the form of three ohase, sixty hertz, alternating current at approximately 13,000 volts.

The voltage sha1l not vary more than 108 from said voltage, momentary fluctuations excepted. 
6. Price and Billing

(a) Recognizing that the term of this contract is for a term of twenty (20) years or more, Masselec is agreeable to a variable rate for guch a term. A definable cost that will serve as a base for Masselec purchases from Clark is the cost of fuel as set out in the New England Power Company (NEP) FERC Electric Tariff. The payment will be defined by Masselec on a monthly basis as follows:

(Weekdays, $7: 00 \mathrm{a.m}$. to $11: 00 \mathrm{p.m.}$ ) $\$ / \mathrm{kwh}=A \times 1.30$ (Weekdays, $11: 00 \mathrm{p.m}$. to $7: 00 \mathrm{am}$ ) $\$ / \mathrm{kwh}=\mathrm{A} \times 1.06$ (Weekends and Holidavs, 24 hours, $\$ / \mathrm{kwh}=A \times 1.06$ $A=$ the average New Eng?and Power Company (NEP) fuel costs for the current operating month.

$1.30 \mathrm{~s} 1.06=$ multipliers used to convert NEP's average fuel costs to incremental fuel costs. These multipliers are subject to modifications, to reflect changes in the relationship between the average fuel cost and the incremental fuel cost.

(b) Masselec will stand ready to scll electricity to Clark during those times when the cogenaration plant canrot provide the total university requirements. The pricing of such service will be the sum of the following:

\section{Distribution Capacity Charge}

$\$ 2.00$ per month per kilowatt of Fistribution Capacity contracted for as a maximum service taking by clark.

\section{Energy Charge}

All energy purchases will be billed in accordance with Masselec's General Rate $\mathrm{C}-22$ as filnd from time to time with the Massachusetts Departmeni of Public Utilities (M.D.P.U.), presently M.D.F.U. Sc. ?74 on dny supercession 
or modification thereto, except that the minimum charge will not apply to this agreement.

Determination of Distribution Capacity

The Distribution Capacity made available to clark will be determined by the capability contracted for as a maximum service taking and for this agreement shall be fifteen hundred $(1500)$ kilowatts.

If at any tiane the Demand as measured in kilowatts ( $\mathrm{kw}$ ) exceeds the capability contracted for, that demand will become the contracted for capability. High Voltage Metering Adjustment

Masselec reserves the 2 ight to determine the metering installation. Where service is metered at Masselec's supply line voltage, thereby eaving Maselec transformer losses, before determining the numbef of kilowatts of demand and kilowatthours to be billed under the preceding provisions; there shall be deducted from the meter registrations of kilowatts and kilowathours for the month in question an amount, respectively, of one percent (28) of such registrations.

(c) If in the future Masselec files with the M.D.P.U. a cogeneration policy and cogeneration rate, and if said policy and rate are approved by the M.D.P.U.; then said cogeneration policy and cogeneration rate will be made available to clark as an alternate purchase price schedule to that presented in paragraph 6 (b) of this agreement.

\section{Rate of Taking, Transformer Capacity}

For the period from the date of commercial operation of Clark's Cogeneration Plant until such time as additional capacity is needed by Clark, and Masselec shall have given written consent, upon timely notice, to an increased level, 
clark may take hareunder electricity (when the cogeneration Plant cannot meet the University's needs) at any rate not exceeding sixteen hundred (1600) Kilovolt-amperes, and for the said period the transformer capacity will be deemed to be 1600 Kilovolt-amperes.

\section{Parallel Operation}

Clark may operate its electrical penerating equipment in parallel

with Masselec's system provided that:

(a) Clark own, install, and maintain protective devices and apparatus that Masselec deems acceptable, and

(b) that clark save and hold harmass Masselec from all claims for damage to Clark's equipmenr or injury to Clark's employees or others on Clark's property arising out of or referable to such parallel operation.

9. Interconnection Responsibilities

The responsibilities of each party to this contractual Agreement which will allow for the interchange of electric energy are described as follows:

(a) Clark will install the necestarv protective devices in its substation in accordance with design drawing No. Clark will to all synchonizing of its electric generator.

(b) Masselec will do ajl work in its substation, at Clark's expense, that will insure the interchange of electris energy, in accordance with decign drawing No. Masselec wjll install the necossarv metering equipment in Clark's substation and at Clark"s axpense, in accordance with deritgn drawing No. lon electricity repistration, for billing purposes and priced according to Taragraph 6 of this agreegent, For Masselec's purchase and sale of electricity. 
(c) Masselec will supply relay settings. Masselec must either set and test the relays, or witness the setting and testing, both at Clark's expense.

10. Metering

All electricity shall be measured in the form of three phase, sixty hertz alternating current of approximately 13,800 volts.

11. Access to Facilities and Records

Representatives of the parties to this Agreement shall at all reasonable times have access to the facilities and daily/monthly information sheets of the other fer the purpose of making inspections and obtaining information reasonably required in connection with this Agreement.

12. Modern Apparatus and Practice

Each party to this Agreement shall use modern standard commercial apparatus and shall exercise the necessary skill and diligence required to secure satisfactory operation in accordance with the best modern practice in order that the best service practicable can be maintained.

13. Pegulations and Franchises

This agreement and all rigt:t, :tligetions and performances of the parties herewirov ,us sulinit to (a) all present and

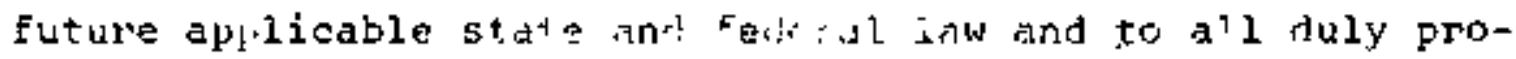
mulgated orders and stlet dui; "stlorized action of grvernmental authority hrving furiscistics in the prenises; and (b) the retention by the partis ar tile i, its uf way, frenchises, locations, permits and ot?."r' $r_{i}$ hto gecessary for the derformance of this Agreement. 
14. M.D.P.U. Approva1

$-46-$

Page 7

Prices to be paid for electricty by Masselec hereunder, along with Masseled's filed Terms and Conditions, Provisicns, and Rates, are subject to review and determination by M.D.P.U. in any proceeding brought under Sections 93 or 94 of Chapter 164 of the General Laws, as amended, to the extent provided for and in accordance with the terms of Section 94A of said Chapter.

\section{Assignment}

This Contractual Agreement shall be binding upon and shall inure to the benefit of, and may be performed by, the successors and assigns of the partips, except that no assignment, pledge or other transfer of this Contractual Agreement by either party. shall operate to release the assignor, pledgor or transferee of any of its oblipations under this dereement unless consent to the release j.s given in writing by the other partv, or, if the other party has heretofore asingred, pledred or otherwise transferred its interest in this Arreement, bv the other party ${ }^{\dagger} \mathrm{s}$ assignee, pledgee or trarisferee.

16. Integration

This document contains the entire arreement and understanding between the parties as to the suciect matter of this Agreement, and merges and supercedes all prjor dgreements, commitments, representations, writines, and ciscussions between them. Weither thisi Agreemont nor any rum or provisions hereof, excluding the multinliers oresented in prosaganh 6 (a), mev be

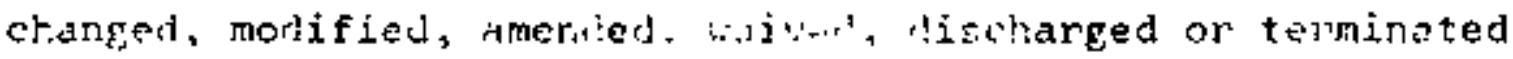
orally, but only $l y$ an 'nstunin' $i$ witing signed by ar officer of the party ajairat $h \dot{i}+$ h tl, ex'oreement of the change,

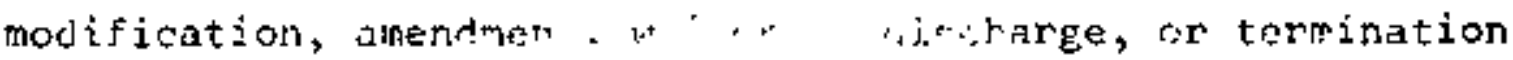
is sought. 


\section{Severability}

Should any provision of this Agreement be held invalid, such provisions shall be considered severable and such invalidity shall not aifect the remainder of the provisions herein.

18. Applicable Law

This Agreement is made in and shall be construed and interpreted in accordance with the laws of the Commonwealth of Massachusetts.

[THIS PRELIMINARY DRAFT CONIRACT IS SUBJECT TO CHANGE UPON LEGAL REVIEW]

BY

TITL:

CLFQK UNIVERSITY

BY 


$$
-48-
$$

\section{MASSACBUSETT'S ELECTRIC COMPANT}

Gemeral Rate C.-22

U.D.P.U. No. 3,4

Purchased ivoter Cost Adjustinent No, 6

$$
\text { iffertive February 1, } 1977
$$

\section{Monthly Charge as Adilusted}

$\$ 2,00$

$16.072 \mathrm{c}$ per 1TH 6.0725 per kWh

4 9S2C per KWH

3.772 \& per KWHit
P1rat

Next

Nert

Next

xce of
20 with or leat per month

80 tond par month 200

1700 2000

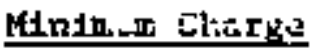

$$
\begin{aligned}
& \text { zisto isc }+\$ 1.87 \\
& \text { Us, } 1.20 \mathrm{KWn}=\$ 2.00
\end{aligned}
$$

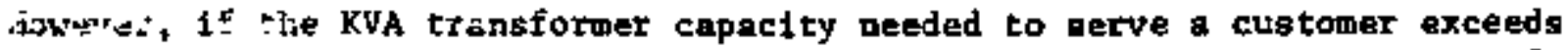
$25 \mathrm{WA}$. tie mintmum charge will be tncreaged by $\$ 1.75$ for each kVA In excese of 25 rSA.

thic. Ke 


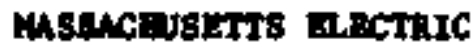 \\ Conparis}

GDiRaL RATE C-22

\section{AVAILABILITY}

Serwice under th1 rate 1s avallable for all purpotes.

Ho service w11 be turnshed hereunder to a Cutconer for regale in wole or In part wthin the territory of the Company, except to a Custoner who wae engeged in tenelling electrictity furn1shed by the Company on Apr11 21, 1958 who may continue to ragell, but only under the aane circunatances or condition, in the aame location and to the tame extent an guch Cuntomer we reselling on said date.

MinHLY claRge
$\$ 1.97$ for the f1tet $20 \mathrm{kllowat}-\mathrm{hourg}$ of 1 egs of electrictcy dellvered esch month,
6.016 cente per k1lowitt-hour for the next $80 \mathrm{kIlowat}-\mathrm{hour}$
5.416 ceate pat k1lowatt-hour for the next 200 kilowatt-houra,
4,306 cents par k1lowatt-hour for the next 1700 k1lowate-hours,
3.116 cente per kilowatt-hour for the exceds over 2000 kilowatc-hours.

\section{PURCHASED POWER COST ADJUSTHEST}

The prices under this rate an oet forth under "Monthly Charge" may be adjuoted froin time co time in the manner provided in the Company's Purcheand Power Coac Adjuitsant Providons to reflect changes occurring on jr after January 1, 1971 in the Primary Service for Resale Rate of the Company's supplier, New England Pnwer Company.

\section{ADJUStheat FOR COST OF FUbL}

The mount determined under the preceding provigions shall be adfusted In accordance with the Company's Standard Fuel Clause as from tine to tine ef fective in accordance with law. 


\section{MASSACLUSETTS RACTRIC COMPAMY}

GENERL RATE C-22

\section{. HINIMUM CHARGE}

\section{$\$ 1.87$ per month.}

Hoilever, If the KVA tranaforeer capactly needed to earve a cuatoner exceeds $25 \mathrm{KVA}$, the mintor charge w11 be Increased by $\$ 1.75$ for each $\mathrm{KVA}$ in excess of $25 \mathrm{KVA}$.

\section{BIMWTHLY BILLING}

The Company reserves the right to read atere and render bill on a b1manthly basia. When bills are rendered blmonthly, the charge for the 1nitial block, the k1lowatt-hours otated 1n each block and the itintmum charge ahall be multiplied by two.

\section{TERMS AND CONDITIONS}

The Company ${ }^{+}$Terteg and Conditions in effact ftot time to tine, there not inconeistent with any specific provisione hereof, are a part of this race. 


$$
-51-
$$

Appendix 2C

Draft

ENVIRONMENTAL EVALUATION REPORT

Table of Contents:

1. Sumbary of Phase II Activities

2. Preliminary Enviromental Impact Assessment

3. Massachusetts Environmental

Assessment Form

4. Individuals and offices consulted 


\section{SUMMARX OF PHASE II ACTIVITIES}

changes in the assessment of environmental impacts were caused by the change of equipment from an engine burning \#2 distilled oil to one operating on $\$ 6$ residual. Th1s new engine and its appurtenances. such as oil treatment equipment, water treatment equipment and auxiliary tanks, changed the configuration of the project, its operational characteristics, and its pollutant emissions. Hajor changes from the environmental impact assessment prepared during Phase I are a reduction in the increase of $\mathrm{NO}_{x}$ emissions and particulates and an increase in $\mathrm{SO}_{2}$ and $\mathrm{HC}_{\mathrm{x}}$ emission. In addition, a liquid effluent is now present. The following sections, organized in the same way as was the phase I report, reflect these changes. Discussions with the regulatory agencies affected do not, however, raise any new problems due to the changes in the installation. 


\section{PRELINIHARY}

\section{Environmental Impact Assessment}

November, 1977

Env1ronmental Impact Assessment (E.I.A.) of the proposed contract EC-77-C-02-4211, "Demonstration of a Gxid-Connected Integrated Community Energy system" at clark University, Worcester. Magachusetts.

Submitted in accordance with the National Environmental Policy Act of 1969 and according to the guidelines promulgated by ERDA on December 8,1976 , and pubiished in the Federal Register, volume 42, Number 17, January 26, 2977, pp. 4926-4833.

Submitted to: The Energy Research and Developnent Administration Chicago Operations office

9800 South Cass Avenue

Argonne, Illinois 60439

\section{Contents}

I. Introduction

II. Description of Proposed nction

III. Description of Existing Environment

IV. Potential Environmental Impacts
A. Positive
B. Regative
1. Construction -- short term
2. Operation -- long tern

v. Coordination with federal, state, regional and local plans.

vI. Description of Alternatives

VII. Conclusion

Submitted by: The Environmental Impact Assessment Group Professor Harry Schwarz, Coordinator

Clark University

950 Main Street 
I. Introducttion

The more efficient use of energy is an urgent national challenge. Nowhere is this need greater than in New England where the energy prices and reliance on imported energy supplies are the highest in the country. In response to this situation, clark Univeraity 19 proposing that it decrease its energy uge through the installation of a co-generation system. This system would involve the generation of electricity on campus by a diesel generator and the utilization of the engine's "waste heat" in the University'g steam heating system. By utilizing the heat that is normally lost in the generation process, the energy efficlency of the co-generating system will be approximately 258 higher than at present.

similar co-generation systems have a proven record of gafety, technologic success, energy congervation, and economīc savings in many European countrieg. 1I. Description of the Proposed Action

The cogeneration system would involve the ingtallation of a Sulzer g cylinder, ASL-30 diesel rated at 1494 Bhp at 900 RPH. The diesel would generate 1405 kilowatts of electricity and provide $3.67 \times 10^{6} \mathrm{Btu} / \mathrm{hr}$ of energy to the University heating plant. When in operation the system will meet nearly all of the University's electrical demand. The system will be integrated with Massachusetts Electric Company. The utility has agreed to purchase electricity generated in excess of the University's demand and to sell electricity to the University when the 
generator is not in operation or otherwise unable to fulfill the University'a demand. The thermal load of the University that exceeds the diesel's output will be provided by the present boller oystern.

The positive environtuental impacts include: (a) the conservation of scarce resources, (b) maintenance of the financial etrength of clark University, (c) the creation of an energy conservation demongtration facility in Massachusetts, (d) enhancement of Clark University's programs and reputation in energy management, (e) additional experience in the design, construction and operation of co-generation facilities by the technical participants, (f) the expenditure of approximately one milion dollars in some of the most economically depressed regiong of the country, $(g)$ a small reduction in the emission of some air pollutants in the New England region, (h) reduction in the negative environmental impacts involved with the extraction, processing and transport of fuels, and (i) decreasing the negative economic impacts that result from New England's dependence on expensive imported oil, (j) assisting in a more positive national balance of payments, and (k) reducing the political vulnerability that results from the nation's lack of energy self-sufficiency.

The anticipated negative envitommental impacts may be associated with the construction (approximately 6 months) or the operations phase. The former include (a) additional traffic on the canpus, (b) the aesthetic impact (audio and visual) of the construction operation, (c) emission of particulate matter (dust) in the local area, Anticipated negative impacts of the 
operational phase include: (a) an increased emission of some air pollutants at clark University. (b) the discharge of a limited amount of water contaminated by oil treatment residues, (c) the noise and vibration of the diesel engine and generator, (d) the increased presence of oil delivery trucks, (e) the visual and physical impact of the building that will house the diesel and generator, (f) the audio and visual impact of the system's small cooling tower, and (g) an element of unknown risk that accompanies the alteration of an existing system. A11 of these impacts, including an evaluation of the significance of each, are discussed in detail in Section IV.

II. Descxiption of the Existing Environment

For the purpose of evaluating the system's environmental impact, the description of the existing environment has been divided into five categories: (a) the present energy system, (b) the building in which the present energy syster is located, (c) the University campus, (d) the surrounding residential community, and (e) metropolitan Worcester.

(a) The Present Energy System. The central heating plant is located in the northwest quadrant of the basement of Jonas Clark Hall (see Fig. 2C-EIA-1). There are three bailers--two rated at $21 \times 10^{6}$ Btu per hour and one rated at $29 \times 10^{6}$ Btu per hour. The peak thermal demand of the university can be met by one of the small and the larger boller. The steam and hot water are piped through a network of underground tumnels to the other buildings on carpus (see Fig. 2C-EIA-2). The boilers can be adapted to burn either residual (\$6) or distillate (\$2) otl, or natural gas. Exhaust from the boilers is vented through a 95 foot 


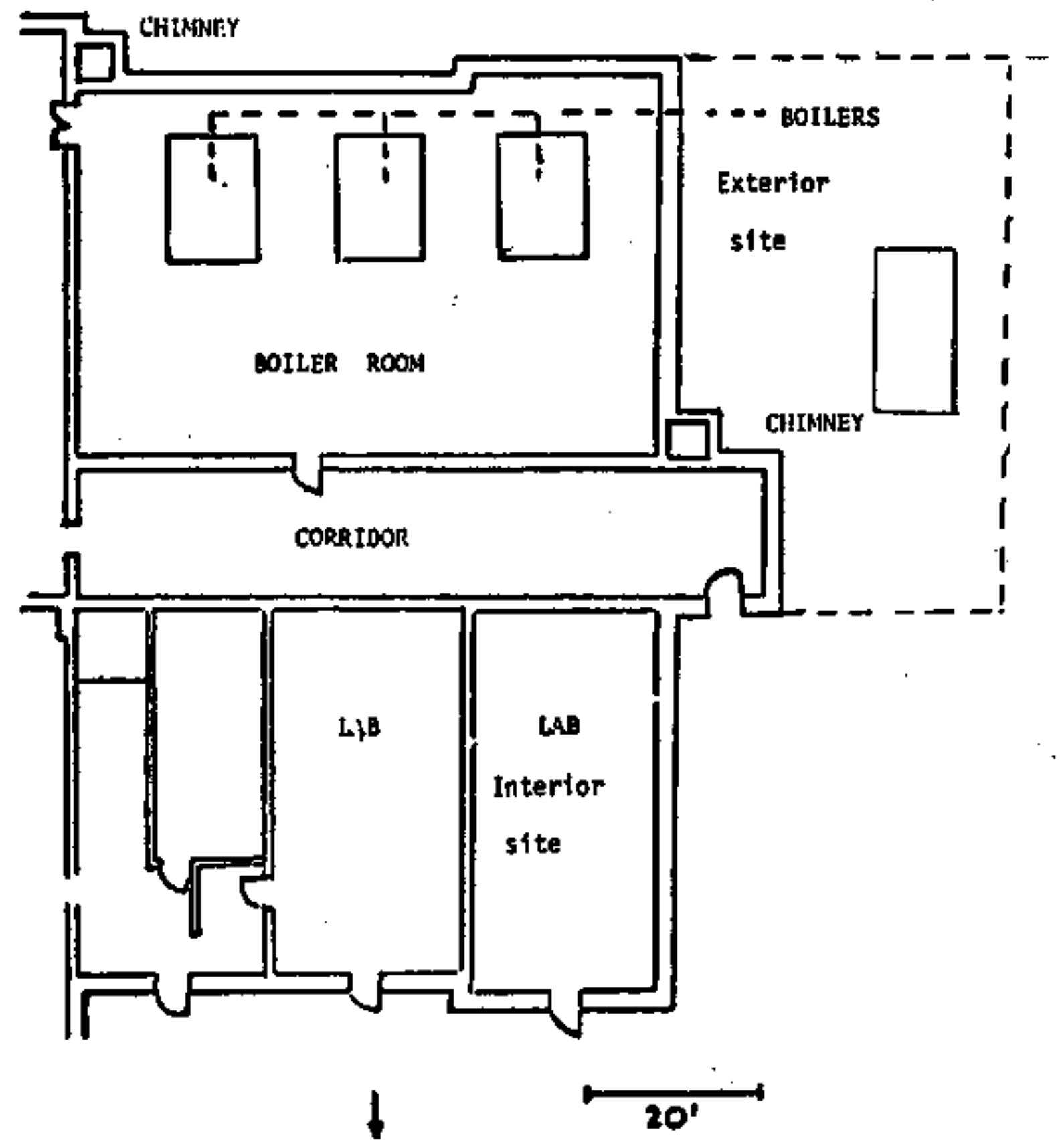

MAIN STREET

Figure 2C-EIA-1. Plan of the East wing of Jonas Clerk Hall, showing the present boller plant simed the space for the possibic griat-conmected KES 


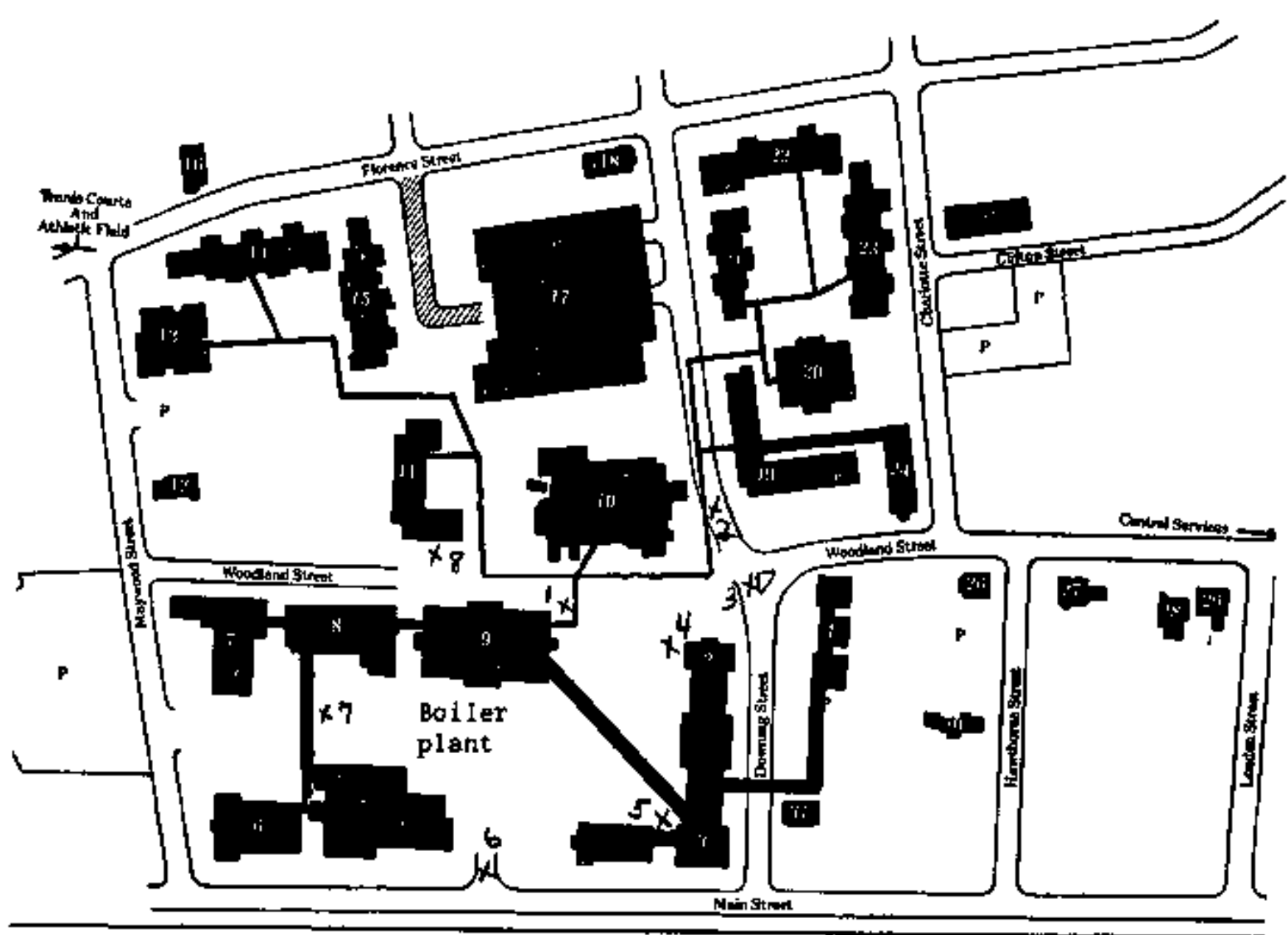

125 psig steam lines
40 rsig steam lines
15 osjo. steam lines

Figure 2C-EIA-2, Stean distribution systen at Clark University. Steam 1 ines in all cases include both steam supply and condensate return.

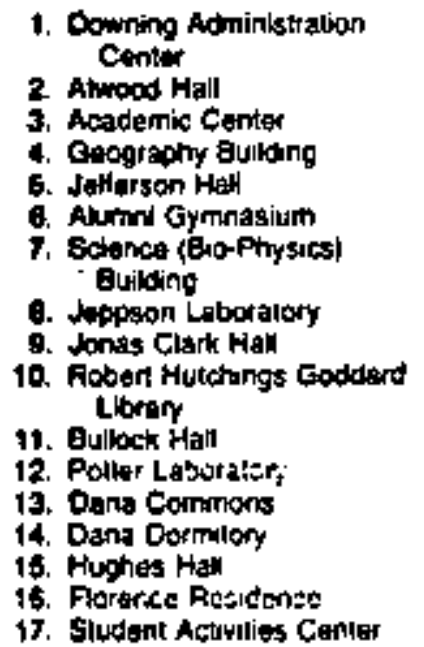

1. Downing Administralion

2. Atwood Hall

3. Academic Center

6. Alumin Gymnasitum

Sclance (Eio-Physics

Llberer

12. Pollor Lasurater,

13. Dana Comanons

14. Danj Dormulony

16. Flororce Residente

17. Sludent Acturlies Cenier

18. General Sionereirth Control Conter

19. Wright Hab

20. Litile Center lor lhe Visual and Pertorming Ants

21. Doda Halt

22. Juhnsan $\mathrm{Hab}$

23. Sanlord $\mathrm{H}$ 이

24 Eslabrook Hall

25. Physicel Plant

26 Alumn Hous?

27. English House

28. Corrage Houss

29. Departument ol Management

30. Nurs ri, Soment'Comment

$$
\text { Lounge }
$$

31. Downing Fesidence

- Peztroums and Fubolic

$$
\text { Tolectinn? }
$$

P Patuing Ares 
etack mounted on the north side of the building. The oil is delivered on campus by tanker truck and stored underground in two 20,000 gallon tanke. The boiler operationg are inspected periodically and meet all Iocal, state, and federal regulations. They are operated by specially licensed personnel.

Electrle power is supplied by Massachugetts Electric Company, a member of the New England Electric System. The electricity is provided by a gingle, 13,800 volt utility line. It is connected to University owned transformers located on the North side of Jonas Clark Hall near the heating plant. Electricity is distributed from this point throughout the campus.

(b) Jonas Clark Hall. Jonas clark Hall is located in the center of the campus (see Fig. EIA-2), It was built in 1887, is a brick construction, has four floors and contains 84,289 grosg square footage. As mentioned previously, the present boiler aystem is loceted in the northwest corner of the building's basement. An old gym, eraftshop, gameroon, three gmall laboratories, and a lavatory are also located in the basement level. The three upper floors are devoted to classrooms, faculty offices, and the offices of the college of Professional and Continuing Education.

Although the sound levels inside the boller room are high (95-85 decibels), the building's thick brick walks, the boiler roon's brick ceiling, and sound proofing reduce the sound levels immediately outside the boiler room to the ambient level. (See Table EIA-1 for specific decibel readings,) The sound reduction Is important since the building is set in the center of the campus. 
Nolge levels at Clark University

\begin{tabular}{lc}
\hline \multicolumn{1}{c}{ Location } & Nolse level (dB) \\
\hline Main street, heavy trucks & 95 \\
Inside present boiler plant & 95 \\
Main Street, normal traffic & 75 \\
Outside window of present boiler room & 70 \\
Residential gtreet at back of campus & 70 \\
Ingide clark computer center & 68 \\
Inside room with people talking & 65 \\
Street enclosed by campus, no cars & 55 \\
Park acrass Main street, opposite clark & 55 \\
Dormitory quadrangle & 52 \\
\hline
\end{tabular}

a Data measured by students in the Progran on Science, Technology and Society with a portable dB meter. . 
(c) The Campus, The University owns 35 acres of land. The area covered by the main buildings and served by the central steam diftribution system 1315 acres. The University owns 46 builalngs, of whlch 21 are considered "major." There 1s approximately 1,000,000 grosg square feet of building space. (Fig. 2C-EIA-2 indicates the layout of the central campus.)

The architectural atyles of the buildings vary considerably, representing a history of the changing perceptions of the "academic style" held by architects and adminiatrators. The result is a combination of modified gothic, Now England mill, high efficiency barracks, and modern irregular. A 12 person aesthetics committee advises on architectural changes that might detract from or intrude upon this architectural melange.

clark is a small unlversity with about 2,000 undergraduates, 250 graduate students, 280 staff members and 140 full-time faculty members. Th1s results in a campus week day population of 2,600 and an evening/weekend population of 1,200 when the Unfversity is in session. Clark has not escaped the recent economic pressures familiar to private universities. Tuition ralses have been a regular, unavoldable feature ag have staff reductions and very modest salary increases for the remalning gtaff and faculty. In the 10 year period from 1965 to 1975 , the University'g total energy costs rose from $\$ 81,000$ to $\$ 560,000$. The University's energy costs in 1976 were $\$ 389,938$, which indicates that clark's efforts to respond to these pressures have been determined and effective. Past operating deficits have been eliminated, active cost cutting measures have been under- 
taken, a major fund raising campaign is underway, energy conservation efforts have reduced thermal demand by 41 s between 1972 and 1976 and electrical demand by 418 between 1970 and 1976 , and imaginative programs have been instituted to both attract superior students and insure the financial stability of the University. The proposed cogeneration system is, of course, one such project. (See Fig, 2C-EIA-3.)

The sound level on the campus varies considerably with time of day and location. Fig. 2C-EIA-2 shows locations on the campus at which sound measurements were made to establish baseline data. Table EIA-2 pregents average and lowest readings taken over several days.

Table 2C-EIA-2

Baseline Sound Data

Average Sound Levels

A curve

\begin{tabular}{ccccc} 
Leve1 & $8 \mathrm{am}$ & $11 \mathrm{am}$ & $5 \mathrm{pm}$ & $2 \mathrm{am}$ \\
\hline 1 & $65 \mathrm{db}$ & 67 & 65 & 60 \\
2 & 60 & 54 & 54 & 42 \\
3 & 62 & 60 & 58 & 46 \\
4 & 58 & 60 & 58 & 51 \\
5 & 53 & 52 & 50 & 44 \\
6 & 68 & 70 & 70 & 49 \\
7 & 55 & 55 & 50 & 46 \\
8 & 57 & 56 & 56 & 50
\end{tabular}

Minimum sound tevels

A curve

\begin{tabular}{ccc} 
Location & db & $\begin{array}{c}\text { Time } \\
\text { Measured }\end{array}$ \\
\hline 1 & 60 & 2 am \\
2 & 42 & 2 am \\
3 & 46 & 2 am \\
4 & 51 & 2 am \\
5 & 44 & 2 am \\
6 & 49 & 2 am \\
7 & 46 & 2 am \\
8 & 50 & 2 anm
\end{tabular}

(d) The community. The University's campus is situated in a residential neighborhood 1.2 miles south of the city center (see Fig. EIA-2). The campus is set in a high density landscape 


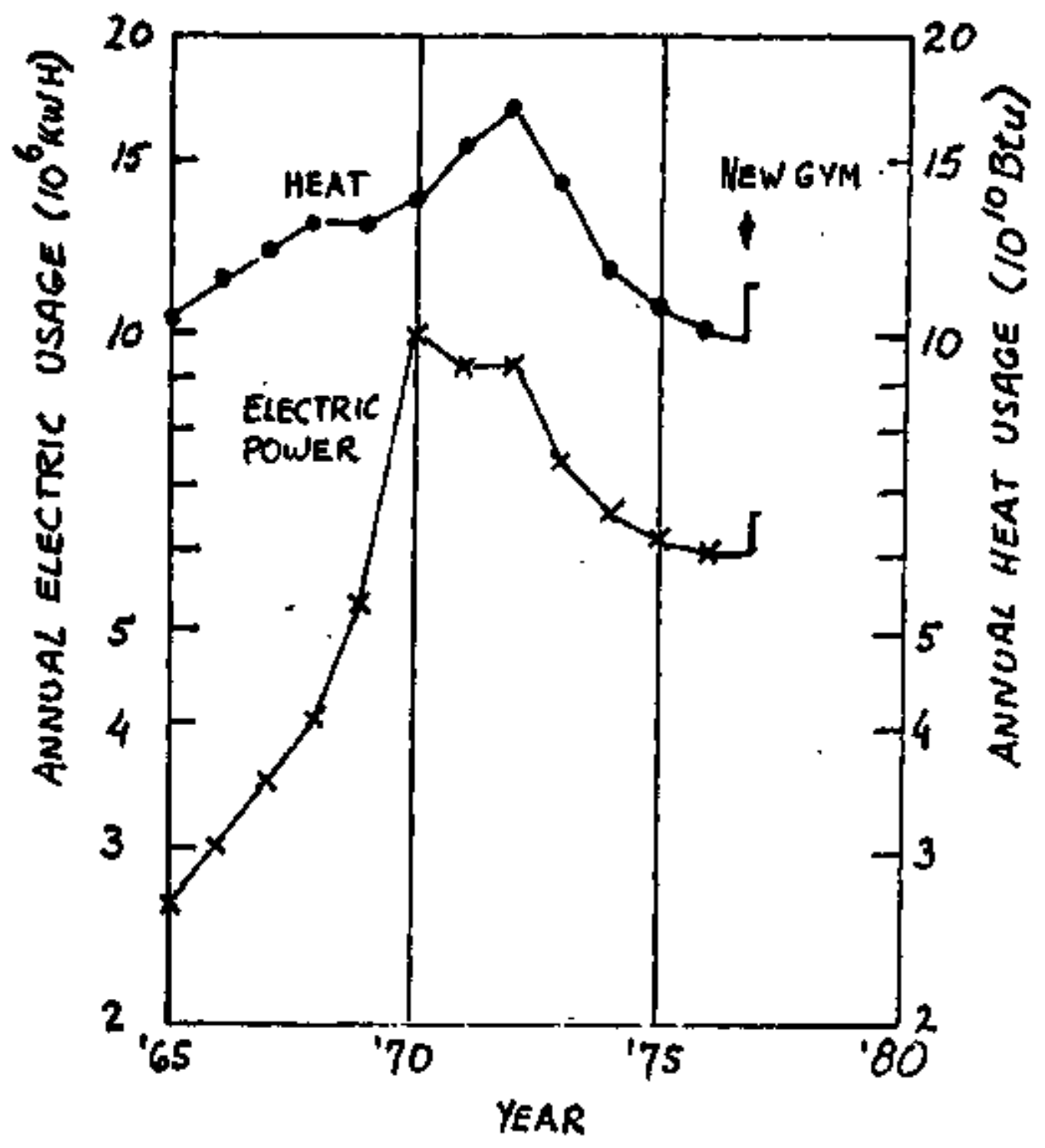

Figure 2C-EIA-3

Illustration of energy consumption at clark since 1970 . 
typical of urban New England. On three sides the neighborhood consists of two and three story houses (triple deckers) located on amall, narrow lots. Some of thege structures are single family residences, but most contain several rental un1ts. The median family income of the area was $\$ 8,819$ in 1975 . Maln street 1ies to the east of the campus. It is a major artery and truck route. On it are located a number of small service oriented businesses, churches, and public sorvice organtzations. The residential neighborhood resumes to the east of the artery (see Fig. EIA-2). The University's relations with the surrounding commundty are generally positive. The primary issues of community-university conflict are all related, but for clarity are presented separately here. (1) There has been a serious lack of student parking on campus. Although the university added 140 new parking spaces in 2976 and will add 200 spaces in 1977 , the problem is otill not entirely resolved. (2) students rent many of the apartments in the area surrounding the campus. Some residents In the communtty feel that this movement has decreased the community's viability. (3) The issue that has caused the most Btress is the University's purchase of adjacent, residential property for expansion. Similar to student apartment renting, the same residents feel that this decreases the number of school age children in the community and jeopardizes the continued operation of the community elementary sehool on Downing st. since the University plang no major future expansion, this aispute should not be an issue in the future. A significant aspect 
of the proposed ICES installation is that it will not affect any of these areas of University-Community conflict.

(e) Metropolitean Horcestes. The city of Worcester has a population of approximately 170,000 and more than 6 million people live within 50 miles of the clty. Although Worcester 1s the second largest elty in New England, it is best described as an old, mediún-sized, industrial city. similar to many cities in the Northeast, the post world war II era has brought changes that have stressed the economic and social fabric of the city. The population has declined as the more affluent moved to the auburba, text1le and related industries have closed, the tax rate has continuously increased, urban renewal programs have met with only partial success, abandoned buildings degrade older neighborhoods, etc. Recently the city's response to theso problems has been more effective and actually reverged many of the negattve trends. The city center is being revitalized, and the exodus of people and industry has slowed, newer service industries are expanding.

clark is one of eleven colleges and univergities of the Worcegter Consortium of Higher Education. These ingtitutions combine to become one of the largest employers in the city. For this and other reasons, the well-being of the region's colleges and univerafties is critically important to the resurgence mentioned above.

Worcegter, like the rest of the North east, suffers from extremely high energy costs. These costs exceed those in any 
other part of the country. Most industries and many individuals have instituted conservation measures and reduced their energy consumption significantly. But further conservation measures, such as Clark's ICES proposal, will be necessary if the city and region are to remain economically competitive in the future. The most persistent, specizic "environmental" problem in Worcegter is the high particulate content of its air. Worcegter is presently "Non-Attainment" area for particulate matter, consistently violating the state air quality stanóards for particulate matter.

A review of the quarterly air pollution measurements at clark, contained in EIA Table 2, indicates that the particulate levels exceed the standards by a maximum of $25 \%$ over the past 5 years. 
Tab1e 2C-EIA-3

Quarterly air pollution at clark

\begin{tabular}{|c|c|c|c|c|c|c|c|c|c|c|c|c|}
\hline \multirow[b]{2}{*}{ Year } & \multicolumn{5}{|c|}{$\begin{array}{l}\text { Total suspended par- } \\
\text { ticulates } \\
\text { (ugm/m3 }\end{array}$} & \multicolumn{2}{|c|}{$\begin{array}{l}\mathrm{SO}_{2}^{\mathrm{C}} \\
\text { [ppb] }\end{array}$} & \multicolumn{5}{|c|}{$\begin{array}{l}\mathrm{NO}_{2}^{\mathrm{a}} \\
\text { (ppb) }\end{array}$} \\
\hline & 1 & 2 & 3 & 4 & 1 & 2 & $\overrightarrow{3}$ & 4 & 1 & .2 & 3 & 4 \\
\hline 1971 & & & 62 & 68 & & & 9 & 14 & & & 78 & 71 \\
\hline 1972 & 76 & 62 & 50 & 46 & 13 & 6 & 4 & 14 & 42 & 34 & 42 & 39 \\
\hline 1973 & 76 & 44 & 43 & 55 & 15 & 3 & 1 & 6 & 29 & 47 & 51 & 24 \\
\hline 1974 & 68 & 62 & 40 & 51 & 12 & 2 & 1 & 13 & 30 & 25 & 21 & 32 \\
\hline 1975 & 63 & 58 & 32 & 40 & 16 & 4 & 4 & 12 & 30 & 24 & 19 & 36 \\
\hline 1976 & 57 & & & & 11 & & & & 29 & & & \\
\hline
\end{tabular}

a. Data supplied by Edward Benoit, District Chlef, Central Massachusetts Air Quality Control District. The numbers quoted are quarterly mean values.

b. Federal and Massachusetts Air Quality Standards for Total Suspended Particulates are.

\section{Primary}

Year

Day
75

260
Secondary (in ugm/m $\mathbf{m}^{3}$ )

60

150

c. $\mathrm{SO}_{2}$ levels at clack are less than $1 / 3$ of typical values encountered in major cities.

a. $\mathrm{NO}_{2}$ levels at Clark are $1 / 3$ to 1.2 of typical values encountered in major cities.

The high particulate content of the air is thought to be a result of the topography of the city. The city is extremely hilly and this results in the use of excessive anounts of road sand in winter. In adaition, the city is located in a basin 
which discourages dispersion of particulates and encourages the development of temperature inversions,

IV. Potential Envi ronmental Impactg

A. Positive. The positive impacts that were listed in section II will be discussed in detail in this section. The conservation of scarce resources is one of the primary objectives of the installation. Measures that result in significant reductions in national oil consumption without serious economic or envirommental distuption must be viewed as positive contributions to the human and physical environment. The significance of these actions is even higher when it occurs in regions which have no indigenous srurces of fossil fuels. The ICEs plant will reduce clark Untversity's total energy consumption from $213.3 \times 10^{9}$ Btu to $171.5 \times 10^{9}$ Btu per year or by approximately 20\%, These figures correspond to a reduction of 284,900 gallons of oil consumed per yeax to meet the University's electrical and thermal needs. The total energy savings are even greater in terms of net energy savings due to energy saved by not needing to extract, transport, and refine the 264,900 gallons of oil per year.

In the context of fuel conservation, the ICEs installation should be viewed as part of the University's overall commitment to reduce its energy consumption. This commitment has been active and effective. Since 1970, the University has managed to reauce its thermal energy demand by $4 / x$ and its electrical demand by $41 \%$. These savings have been achieved through the 
efforts of students, staff and faculty, energy use atudies, the improved efficiency of end use equipment, an IaM system load dropping computer and improved thermostatio and electrical controls.

The maintenance of the financial strength of the University is a significant attribute of the ICES proposal. The cost of fulfilling the energy requirements at clark in 1975 was $\$ 560,000$. Th1s amounts to approximately 20 \% of the amount spent on faculty oalaries at the University. Reducing these figures by 20 s would be a very positive economic impact. since other conservation measures have already been successfully implemented, the ICEs installation is the only practical means of further reducing the University's energy cost burden.

clark is a private university and tuition costs have increased dramatically over the last decade. Already many individuals are exçluđ̄ed from attending for financial reasons. The savings from the ICES will help to reduce further tuition increases, maintain the University's ability to compete for the most qualified students, and hopefully, renew opportunities that were previously closed due to high tuition rates. It should be pointed out that presently clark benefits from a declining block rate pricing structure. The projected savings of the ICES will be larger if these rates move towards more uniform rate structire.

The creation of an energy conservation demonstration Eacility in Massachusetts would be a positive contribution of the ICES installation. Establishment of a co-generation demon- 
atration plant, of a size and scale appropriate to many industrial, commercial, institutional, and public facilities would be an important asset to the region. The effect that the ICES would have as a demonstration site encouraging similar conservation efforts by others is the primary reason the project has received the attention and support of the Commonwealth's Governor and Energy Policy office.

Three factors insure that the ICES installation will provide an effective demonstration facility. First, Worcester is unusually accessible to the rest of New England. The city's motto "The Heart of New England" implies and its location on I-90 and I-290, functioning train statiou and airport insure ease of access to the facility. Over 508 of the region's population lives within 50 miles of the clark Campus. Secondly, the University has established an impressive record in monitoring and recording its energy use patterns; The Science, Technology and society program at Clark has devoted three issues of its journal to energy use at the university. Finally, the demonstration facility would include information on the University's other conservation. efforts which, as noted above, have been extremely effective. The rCES will enhance Clark University's programs and reputation in energy mantgement. clark has become a center for a considerable amount of research in the energy field. This research has ranged from projects in methane gas digestion, solar energy, wind energy, conservation technologies to funded research in the societal risk of nuclear power, the electric utility-solar energy interface, and methane gas generation from waste treatment 
plants. Students and faculty in two departments, Geography and Physics, and two Programs, Environmental Affairs and science, Technology, and Society, have been particularly active in the field of energy research. A co-generation facility on campus would provide numerous new research opportunities. Installation of an ICES system at the Univergity would enhance the University's position in the energy management field.

The ICES installation will result in additional experience In the design, construction and operation of co-generation facilities by the technical particlpants. Although the concept of co-generation has been understood for many years and many such facilities exist in Europe, there is relatively little technical experience with them in the United states. Installation of the ICES plant at clark should be considered an important addition to this experience. This experience is an important addition to the technical resources that the nation will need to respond to the energy crisis. Since this installation will play a significant role in moving co-generation from theoretical concept to political reality, the increase in the knowledge gained in dealing with the issues involved in eash step (design, construction, and operation) is a very positive impact resulting from the ICES.

The expenditure of approximately one million dollars in some of the most economically depressed regions of the country. The ICES installation will involve the dispersal of about one million dollars in the national economy. The money will help generate jobs in the regions where unemployment has been most 
pergistent and severe -- New England and the Upper Mid-West. In New England many of the jobs will be in the congtruction field where unemployment levels have been especially high. If the clark University ICEs acts as a stimulus for other installations (as is expected), the positive effect on reglonal employment levels would be even more significant.

A reduction in the emission of some air pollutants will occur because the increased efficiency of the ICES will result In reducing total oil consumption by 294,900 gallons. The savings will be at the Massachusetts Electric generating stations. Assuming that the fuel not consumed is residual oil, the emission of particulate matter will be reduced by 2.7 tons/year and So; emissions will be reduced by 22.9 tona/year. (See ElA Table 4.)

Reduction in the negative environmental impacts involved with the extraction, processing and transport of fuels. The 284,900 gallons of oil that is conserved by the ICES installation also contributes to the reduction of the negative effects often associated with drilling, refining and transportation of 011. This positive impact is not very significant, but it is a factor that should be considered when evaluating the decisions that may encourage or discourage che widescale use of ICES. Decreasing the negative economic impacts that result from New England's dependency on expensive imported oil. New England's dependency on more expensive, foreign oil supplies contributes to the region's high cost of living and higher operating costs for business establishments: Electricity rates in the region are 
particularly high and act to discourage the growth of industries that use large quantities of that source of energy. In addition, the region is particularly vulnerable to actions that reduce the availability of oil shipments. Installations of the ICES would reduce the region's dependence on foreign supplies and vulnerability to another embargo. As such, lt would improve the economic potential of the region significantly.

Assisting in a more favorable balance of trade. since the rapid rise in oil prices in 1973 , oll imports have consistentiy been the most expensive item imported by the Uniteo States. With oil imports now exceeding domestic production, the ability of the nation to maintain a surplus halance of trade will be severely tested. Installation of the ICES system will decrease the outflow of money. Presently, approximately $75 \%$ of New England's residual ofl is from foreign sources charging $\$ 12.00$ a barrel. At these rates, the ICEs would save $\$ 82,000$ per year, a small amount when compared to the billion doliar trade flgures, but still a savings.

The political vulnerability that results from the nation's lack of energy self-sufficiency. As stated in the proposed National Energy Plan, complete energy independence is an unrealistic goal. Nevertheless, programs that reduce the nation's need to import foreign supplies of oil and gas do reduce the influence that fossil fuels have on the political decision-making process. The fuel conservation of the ICES installation will contribute positively to the nation's political environment. 
IV. B. The Negative Environmental Impacts

The potential negative environmental impacts of the construction and operation of the ICES were 1 isted in section II. They are discussed below in greater detall.

Construction phase. The negative impacts of this phase are like those associated with similar construction projects. The length of the construction phase is difficult to estimate at this point in time, but it is probably about 6 months long. The negative impacte that will be experienced in this phase Inelude:

Additional traffic along Downing Street and at the site on the north side of Jonas Clark Hall. Since Downing Street is near and Jonas Clark Hall ig at the center of the campus this will have disruptive effect. The inconvenience of heavy machinery on the conpact campus will be greatest when the excavation equipment, dump trucks, and cement trucks are on campus.

The aesthetic impacts, both audio and visual, will persist throughout the construction phase. This impact should not be too great Bince the installation is not a large construction project, yet it is located in the center of the campus. clearly, it w111 be necestary to insure that the most disruptive aspects of the construction phase be conducted when the University is not in sesston.

Particulate emissions, primerily dust, will be generated during the production process. Although these emlssions will not be slgnificant; they are mentioned here becaause of Worcester's air particulate problen. 
In summary, the negative environmental impacts of the construction phase are mainly related to inconvenience. To keep this inconverience to a minimum, it is important that the constructian be undertaken during the late spring and summer months when the University is not in session.

B. The Operations phase. The negative environmental impacts of the operations phase are considered to be more important than those of the construction phase because that phase will be relatively brief. The negative impacts of the operations phase include: An increaged emission of some air pollutants. While the ICES will reauce some emisgions, No $x$ emissions will increase by approximately 86.5 tons, Co wil increase by 23.9 tons and HC will increase by 10.0 tons. The air quality impact is more negative if only the Worcester region is considered linstead of the New England region which includes the Massachusetts Electric generating plants). clark's impact on the local air guality is listed in Table EIA-4. Worcester is a "Non-Attainment" area for particulate matter. at the present time. In the local area, emissions in thia category will be decreased by 0.3 tons. The NO emissions do represent a major increase both at clark and in the New England region. However, levels of $\mathrm{NO}_{x}$ in the worcester region are well below the anbient standards and there is no photo-chemical smog problem in the region. It should be noted that the Regulations as Amended for the Control of Air Pollution exempt diesel engines from No $x$ limits. In addition, $\mathrm{NO}_{\mathrm{x}}$ is a dispersing pollutant, so higher emissions will not result in significantly higher concentrations at the site. As a result of these factors, the $\mathrm{NO}_{x}$ emissions do 
not appear to result in a significant negative impact in the opinion of the EIA team and the Director of the Central Massachusetts Air Quality Control District. However, these emissions will be critfcally reviewed in the Air Quality Analysis at a later stage in the design process.

Liquid effluent. Oil treatment equipment will produce an effluent of gallons per hour containing approximately and 18 of oll. Hater pretreatment prior-to discharge of this waste will reduce the oil content to $80 \mathrm{ppm}$. Noise and vibration of the diesel engine and generator. These impacts are potentially significant but can and will be eliminated through proper design and construction techniques. To insure that vibration is kept to a minimum, the diesel and generator will "float" on a cement pad independent from Jonas clark Hall. Sound proofing will be applied to insure that the ICES will meet the noise standards as specified by the Commonwealth and approved by the EPA. Nolse levels at other co-generation Installations indicate that noise reduction should not be a difficult process. Commonwealth Gas Corporation's co-generation plant in Southborough, Mass. reduces the noise levels from 95-104dB in the generator room to $61-66 \mathrm{~dB}$ in the observation room with standard construction techniques.

The increased presence of oil delivery trucks will result from the increase of 455,900 gallons of fuel consumed on the Clark Campus. At present there are approximately 123 deliveries per year. The ICES installation will require about 57 additional deliveries per year. This represents an increase of nearly 508. Aside from their vigual and olfactory impact, the increased 
Table 2C-EIA-4

Estimated Air Pollution Impact--Present system and Proposed Grid Connected ICES

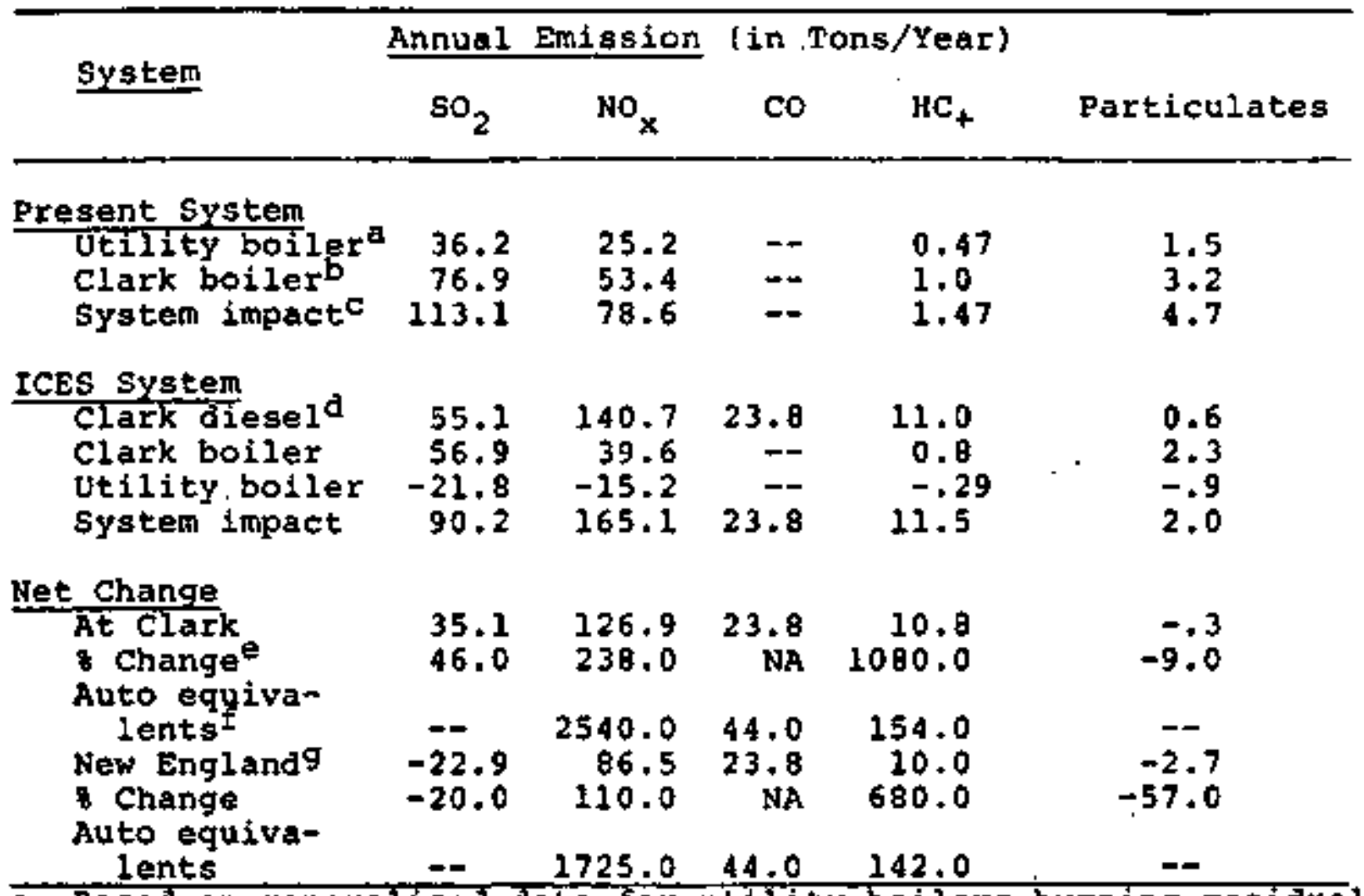

a. Based on generalized data for utility boilers burning residual oil with an ash content of 0.04 (by weight), sulphur content of 1.08 (by weight), weight of 7.83 lbs. per gallon, 148,000 Btu per gallon and Btu to $\mathrm{kwh}$ ratio of 10,050 to 1 . Assuming the consumption of $6.8 \times 10^{6}$ per year.

b. Based on the use of residual oil with the same characteristics as specified in note a agd a boiler efficiency of 758 . Assuming a thermal load of $109 \times 10^{9}$ Btu per year.

c. Carbon monoxide levels (less than .01 tons) are considered negligible here.

d. Based on the manufacturer's specifications and the use of $\# 6$ residual oil with an ash content of 0.048 (by weight), sulphur of 18 (by weight), a weight of 7.83 lbs per gallon, and an energy value of $14 \mathrm{~B}, 000 \mathrm{Btu}$ per galion. Assuming operation at full capacity for 7750 hours per year.

e. The percent change for carbon monoxide is meaningless since bastcaliy none was emitted previously.

f. Auto equivalents are included to provide a means of evaluating the relative aignificance of the net changes. They are based on EPA's estimates for the average emissions of all the motor vehicles operating in the U.S. in 1976 .

g. The New England figures represent the net additional emissions of the Clark ICES and net reduction in the emissions at New England Electric system"g residual o11 fired generators. Assumes a net reduction in NEES's oil consumption by 279,000 gallons per year. 
presence of 8000 gallons fuel trucks carries with it an element of risk. The increased presence of these trucks is only considered significant on the Clark Campus and Downing street. other streets, such as Main street, are major truck arteries and 60 more trucks per year will be insigniflcant.

The visual and physical impact of the ICEs builaing. The system will be installed in a separate building on the north side of Jonas clark thall. This location will require an addition of about 40 by 60 feet. This building will have an effect on the appearance of Jonas Clark Hall which is a focal point of the campus. The University Aesthetics Committee will review these proposals before a final decision is reached. The location will also intrude upon the campus, which is already lacking in "green space." However, this location reduces the levels of unknown risk that are involved with installing the gystem within the 90 year old building. The audio and visual impact of the cooling tower may produce negative impacts. A more definite evaluation will be presented after the exact sizing and location of the cooling tower is c'etermined.

Elements of unknown risk accompany any alteration of an existing system. To reduce potential of this negative impact becoming significant, the ICEs system will uge only proven equipment and engineering techniques. The experience of the technical partners in co-generation showld reduce this threat still further. In summary, the known negative impacts from the ICEs are not deemed gignificant. It should be noted that the ICEs syatem's negative impacts are relatively contained within the clark University campus. As a result, almost al1 of the negative impacts 
are experienced by the same people who benefit from the more signiflcant positive impacts. Negative impacts on third parties, such as the local community, are minimai.

v. Coordination with Federal, State, Regional and Local Plans..

The ICES Installation is only feasible if it can comply with all of the appropriate statutes, coces and regulations. The lmportance of complying with these legal and institutional factors has been recognized throughout the planning process. Aside from these specific factors, it is also important that the ICEs not conflict with any policies and programs of Federal, state and local governments. The relevant items and the steps that have. been undertaken in response to them are discussed below. The specific codes and ietters from appropriate regulatory and planning officials are contained in Appendices 2B and $2 \mathrm{C}$.

Environmental Impact Analysis. Regulations regarding overall environmenta? impact analysis are presented in chapter III, U, $\$$ Energy Research and Development Administraíon. Part 711 - GuideIlnes for Environmental Review published in the Federal Register. 26 January 1977, pp 4826-4833. (See Appendix 28!. These regulations require that an Environmental Impact Assessment (EIA) be 
written as specified in Part 711 - 25 of the regulations. This document is a preltminary draft of an EIA based on the present atate of knowledge on the clark ICES Installation. This report W11 be updated and expanded as the planning process continues. The applicability of the state requirements for an environmental impact assegsment is unknown at the present time and will depend on the degree of involvement of the commonweath in the ICes project. A preliminary draft of a Massachusetts Environmental Assessment Form is included as section 3 of this report. It was completed in accordance with specifications contained in "Preparation of Environmental Impact Reports" (see Appendix 2B). Air quality standards. The exhaust emissions of the rces installation are subject to state and Federal air quality standards. The main applicable regulations are the Federal and Massachusetts Air Quality standards (40 CFR 50), Requirements for Preparation, Adoption, and submittal of Implementation plans (40 CFR 51). Interpretive Ruling for Implementation of the Requirements of 40 CFR 51.18, and Regulations as Anended for the Control of Alf Pollution, Dept, of Enviromental Quality Engineering, the Commonwealth of Massachusetts as amended through 13 June 1975. (A1) of the above regulations are contained in Appendix 2B).

Emissions figures have been reviewed by Mr. Edmond G.Benoit, Chief, Central Massachusetts Air Quality Control District. Mr. Benoit has stated that, based on presently available data and pending more detailed analysis, the project would not be in 
violation of afr pollution regulations (see letter in Appendix 2c). Morsover, Mr. Benoit is very suportive of the project and 1te ability to provide better data as to the air quality impact. of co-generation systems. The staff of the Central Massachusetts Air Quality Control District will be asked to reconmend the most appropriate monitoring equipment to gather this data.

Further discussions have been held with air quality special1sts at EPA's Region I, Boston office. They confirmed that compllance with all state standards wild also guarantee compliance with Federal regulations.

Nolse regulations. The Director of the Central Massachusetits Alr Quality Control Board has jurisdletion over noise pollution under the Regulations as Amended for the Control of Air Pollution, Dept. of Environmental Quality Engineerıng, Commonwealth of MasBachusetts, adopted $26 \mathrm{Jan} .1972$ and amended through $13 \mathrm{June} 1975$. (See Appendix 2B). He foresees no difficulty in meeting these standards. Representative of the EPA noise pollution branch in Boston also have been contacted. Thev staten that the Commonwealth'g standards either meet or exceeded theirs and would be acceptabie.

Building codes. The applicable building codes are contained in Article II, "Heating Equipment and Appliance mounting, clearances and Connections." of the state Building Code. In adition, bollers and unfired pressure vesseis are subject to the provisions of Chapter 146 of the MGLA as amended. These issues 
have been reviewed with Mr. Norton Remmer, Commisgioner, Dept, of Bulding Code Inspection of the city of worcester. Commisioner Remmer stateg that compliance with all reguirements of the bullding code can be achieved by applications of standard designs and construction techniques. (See letter in Appendix 2c.) The provisions of Chapter 246 reguire the approval of certain boilers and pressure vessels by the Board of Boiler Rules of the State Department of Public Safety. Such approval will be obtained, if appropriate, once detailed designs and specifications are known.

zoning. The city of worcester zoning ordinance applies to the University and the ICES installation. Clark is located in a realdential district which is permissible under Section 15A (6) of the code (See Appendix 28). The ICF.s installation was discussed with Mr. Remmer, Commissioner, Dept, of Building Code Inspection, city of worcester. He stated that the project would not violate existing zoning requlations (See lettex in Appenax 2c). The office of Community Planning and Development was also contacted to insure that the enstallation djd not interfere with the plans and programs of that agency. They indicated that the project would not affect their plans. The worcester Redevelopment Authority, an agency that operates in the vicinity of the Clark campus, has also indicated that they have no objection to the ICES installation (See letter in Appendix 2C).

To conclude, the clark ICES proposal does not conflict in a significant manner with any specific legal and institutional requirements or the plans and policies of related governmental 
$-83-$

arencles. On the contrary, the majority of these entitiea eupported the ICEs proposal on the basia of the positive 1mpacts nach a pyetem would have on energy conservation and economic velfare of the community. The advice of the regulatory personnel heve been of gxeat assistance to the Environmental Impact Aaeasment Group. The Group will continue to beek their advice and opinions in the future.

VI Deecription of Alternatives.

There are four getg of alternatives open to clark University. Those being: (1) to continue with present practices; (2) to inatltute additional strong conservation measures to reduce enexgy demand (3) to Install a totally independent integrated energy byatem or (4) to gelect a different grid connected ICES aystem. Continue with present practicen.

Thle alternative would have no environmental 1mpacts at clark Inlversity, it would however continue unabated use of ofl within the New England area. This would, therefore, be contrary to the national and regional objective of fuel conservation. Furthermore, it would continue clark"s vulnerability to cost increases in fuel and electricity with the inherent danger to 1ta financial stability and the indirect effect of financial ingtability on the gtudent body, the faculty and the community. Institute additiona 1 conservation measures.

The Undvergity has already instituted strong conservation measures. The principle one being an IBM system 7 load dropping 
computer which has 26 electric controls and 13 steam controls. The computer in programmed to balance loadg, essentially redueing peak demand. The introduction of this conservation device In conjunction with gimpler conservation rules has already resulted in a reduction of about 35 for the thermal load and 45s of the electric load. Invegtigation of further conservation measurea indicate that such meagures are likely to produce adverse effects on the clark community, produce increasingly marginal congervation ylelds and as a corrolary, Increases in marginal costs. Fuel savings would be oniy proportional to energy input. reduction with no improvement in fuel to energy conversion efficiency.

\section{Independent integrated energy system}

Total energy plants for the clark campus not connected with the exloting electric grid have been investigated in geveral studies. Such systems have generally the same advantages as a gria connected ICEs. Cost, however, are higher as system's reliablifty must be achieved by the installation of standby unite. Englneering studies show that the cost of interconnection including standby charges for electricity are lower than those of standby units.

\section{Different grid connected ICES}

A large number of alternative ICES installations including differently sized diesel undts, stearn turbines and gas turbines were invertigated. These investigations showed that diesel units produced the best balance between efficiency and tech- 
$-85-$

nologic rigk, that generally larger unite produced a... -ased efflciency and rate of return and also higher initial cost. On environmental groundg few differences can be ascertained except that larger unitg are likely to increase aesthetic problems, air pollution but reduce oll consumption. On economic grounds, larger units in addition to increased initial cost, represent hlgher opportunity cogt and larger riska.

\section{Conclugion}

Based on the previous section of this environmental assessment, the following conclusions can be derlved.

(1) There w111 be no significant negative or positive environmental 1mpacto at the project site, i.e. the clark canpus. Phystcal changes will be minimal and do not affect ecologically benaitive areas. Aesthetic effacts and noise effects can be mitigatad by proper facilities design. Air pollution effects at ate will be minimal as the increase in pollutantg that have localized affects such as $\mathrm{CO}, \mathrm{SO}_{2}$ and partlculates Ig samIl. (2) Socio-economic effects at the project site are beneficial. SIgnificant financial savings accrue to clark University and the presence of the deomonstration project will enhance the reputation and academic programs of the University.

(3) Community environmental effects of the project are negative, however, only to a small degree. The significant output of No $x$ w11 increase the ${ }^{N O} x$ level in worcester. This however is not serlous as the present ambient $\mathrm{NO}_{\mathrm{x}}$ level ig well below ambient 
ttandarda and there are no local photo chemical smog problems. Trafflc in the area aurrounding clark will be Increased lightly by the increased frequency of oil delivery trucks and there may be some temporary nulsance conditions during construction. (4) Socio-economic effects on the commnity are expected to be small but positive. The increased local expendlture for conBtruction, operation and thaintenance should to some degree enhance the community.

(5) Regional environmental impacts of the project are sma11 on a national scale but they are positive and as a demonstration profect, this 1o highly significant. Oil savings of nearly $B 000$ barrels per year moy not be large when compared with the pregent natlonal consumption of that fuel, but being nearly 258 of the fuel consumed for clark's need, they are a significant indication of the contribution that grid connected ICES can make towards the national goal.

(6) Regional and national socio-economic impacts, while insignifleant by themselves, are important as indicators of the opportunities that exist, through cooperation of individual institutions, utilities and government towards achlevement of bocio-economic goals.

(7) The overall increase in the emission of nitrogen oxides, carbon monoxide and hydrocarbon indicate that the increased efficiencies of co-generation systems are not without environmental cost. The increases from a single ICEs at clark are not 
$-87-$

considered significant. However, it is important to project the Impact of many ouch installations to gain a more thorough understanding of the total environmental impact. Aa a demonstration project, the clark ICEs wiI provide more precise data to anticipate the ge impacts. At present, the figures suggest that large number of diesel powered ICES should not be Installed in regions with high NO $x$ concentrations or high incidence of photochemical snog without careful evaluation of their impact. 


\section{ENYIRONMENTAL ASSESSAENT FORM}

Plesse read Enwironmental Assessment Form Manual belore filting out this form.

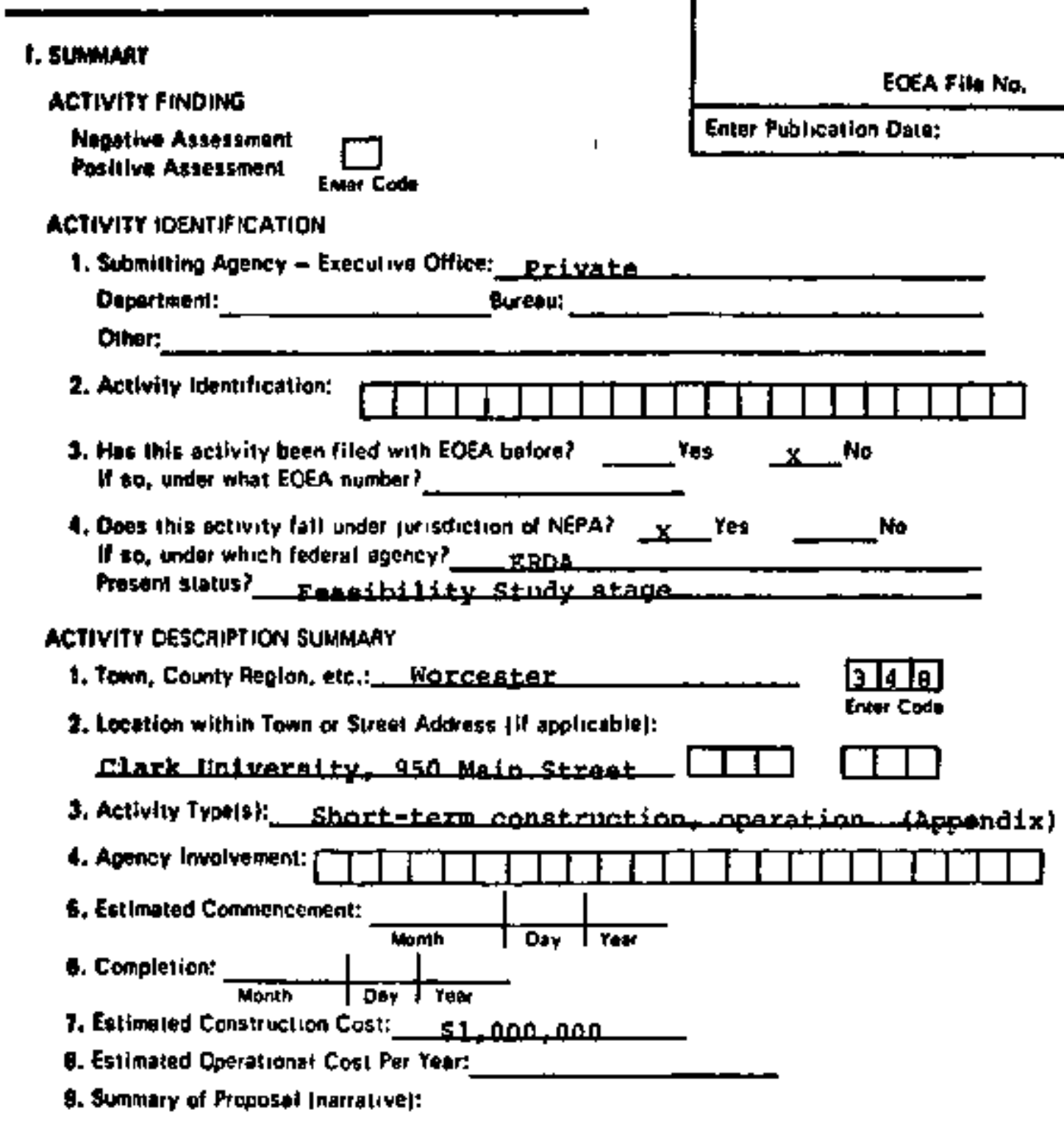

See attached Page

COPHES OF TIIIS ASSFSSMENT MANY GE ORTA INED FROM:

Name: Telephone: Cost Per Copv:

Atderts s: 
9. Simmary of Proposal (narrative):

The co-generation systen would involve the installation of a sulzer 8 cylinder, ASI $/ 30$ diesel rated at 1494 BHP at 900 RPM. The diegel would generate 1405 kilowatta of electricity and provide $3.67 \times 10^{6} \mathrm{btu} / \mathrm{hr}$ of energy to the university heating plant. When in operation the system will meet the University ${ }^{\dagger}$ entire electrical demand. The system will be integrated with Massachusetts Electric Company. The utility has agreed to purchase electricity generated in excess of the Iniversity's demand and to sell electricity to the university when the generator is not in operation or is otherwise unable to fulfill the University's demand. The thermal load of the university that exceeds the diesel's output will be provided by the present boiler system. 
14. ACTIVIT DEscaiption.

$-90-$

A. belude an of lpinal BK a 11 bection of a U.5.G.S. 74 minute, 1:24,000 scale map with the ecilulty or project area boundaries delinealed. \{Original U.S.G.S. sheel required for filling -ith Socretary onlyi eopies may be supplied to others.) include multkple maps il actlvity or Frojact is lerger Ihan the arga delineated on a U.S.G.S. 1:24,G00 scale map. Inetude maps. diaproins or skotehes at a larger scale if the leatures of the ectivity or project connot bo eleurly shawn at the 1:24,000 scale.

A. Cive a brief description of the presem use of the srea or arease affected in 5. Indicate the number of acres affected that are:
1. Developed
\begin{tabular}{l|l|l|l|}
\hline$\square$ & 0 \\
\hline
\end{tabular}
3. Wetlend
पIIDA
i. Oron spece.
4. Shoreline

6. 8ẹe. Attached

C. Gine a brof description of the proposed ectivity, Including all phases and characteristica; in. 2.

1. Fill in the following dimensions. If applicable:

- Totel Activity
Ares (Acrea):

b. Longth In Milog:

C. Number of Hous.

Ing Units:
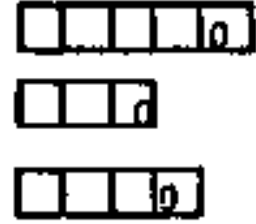

d. Number of Storien:

9. Nuntuer of Parking

Spaces:

f. Vehicular Traftic Gen. erated Por Doy:
In
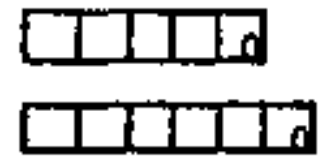

2. See Attached

D. Describe how your apency ls invalyed in the ectivity in 4. spocifir:

1. Permlt or Program Trpe:

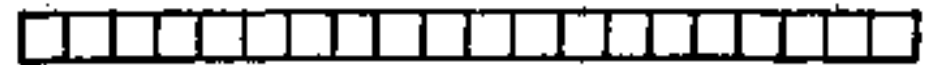

2. Pertirent Governing Statuae(s) of Regulation(s):

3. Othaf State Agentios involved:

4.

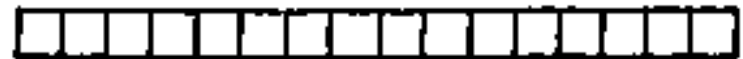


B. 5 .

The present use of this area adjacent to Jonas clark can be described as a small open space plot. Location of the glass enclosed structure housing unit will, in the belief of this team, enhance the aesthetic value of this area.

c. 2 .

The proposed action involves the installation and operation of one $1405 \mathrm{KW}$ sulzer 8 cylinder ASL/30 diesel, 1494 BHP at $900 \mathrm{RPM}$. The machine is expected to operate $7750 \mathrm{hrs} / \mathrm{yr} \mathrm{w} / 110^{\circ} \mathrm{hrs}$ of down-time or maintenance.

The rate of fuel consumption and exhaust specifications as supplied by the manufacturer are as follows:

Fuel consumption: $.357 \mathrm{lbs} / \mathrm{BHP} / \mathrm{HR}$

Exhaust Specs : : No $\quad 8.3 \mathrm{gr} / \mathrm{BHP} / \mathrm{HR}$

$\mathrm{CO}: \quad 1.4 \mathrm{gr} / \mathrm{BHP} / \mathrm{HR}$

$\mathrm{HC}+: .65 \mathrm{gr} / \mathrm{BHP} / \mathrm{HR}$

Particulate: .03i gr/BHP/HR

$\mathrm{SO}_{2}: 3.25 \mathrm{gr} / \mathrm{BHP} / \mathrm{HR}$

It will continue to afford a view of the Goddard Library as well as the Jonas Clark facade. As the structure itself will highlight the operation of the facility, an educational function--for the University as well as the community--will be served. 


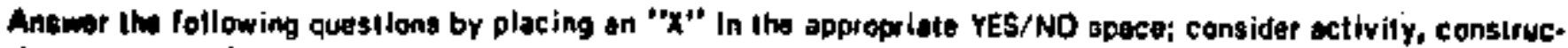
llon, opetetional, as well as indirect impacts.

thdienta under "Explangrion" why signilicant impact is congidered like ly or unlikely to result.

A. OPEN SPACE AND RECAEATION

1. Might the aclivity wfect the condition, uge $\alpha$ acceas to ony open space end/o recreation area?

If YES, spocily arealal and acroage(s\} affected:
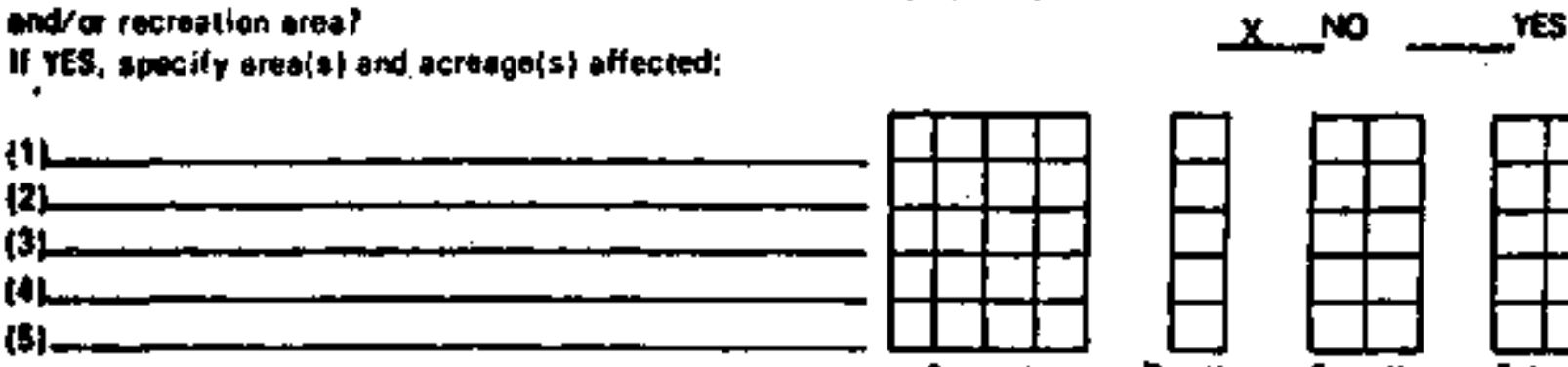

2. Explanation:

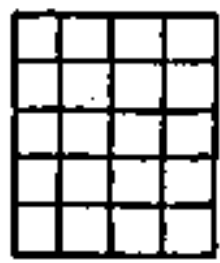

Acrisat:

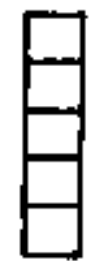

Duration

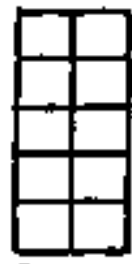

Soverity

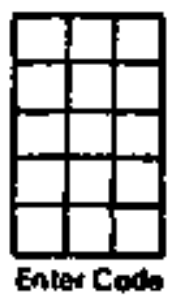

No significant impact on use or access to any open space and/or recreational area $1 \mathrm{~g}$ expected, as the location of the facility iv not in or near any such area.

\section{Histonic RESOURCES}

1. Might eny site of structure of historic signitlcence be sflected?

If YES, state tevel of hlstoric significance:
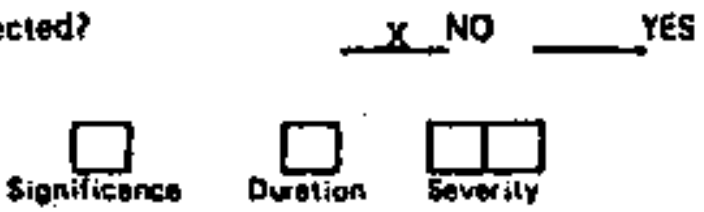

2. Might eny known arehoeologic site be affected by the activity? If YES, specity duration and severity:
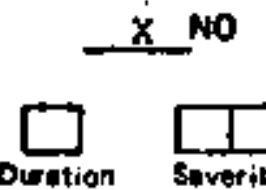

Durtion
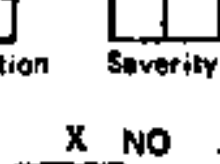

3. Hight amy known paleontologic sile be affected by the activity? If VES, specify duration and severity:

\section{Explangition:}

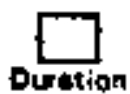

No stgnificant impact 1 s expected on any historical, archaeological or paleontological aite ss the location area has undergone previous excavation - piping, etc. - without damage to any of the above.

After checking with the necessary comisisions it has been concluded that the project io not located in a senaltive area. 


\section{ECOLOGICAL EFFECTS}

-93 .

1. Might the octivily allect any mofural feeturo adjacentl to of near the ectivity area?

It YES, specily nabural fealures aflected:

(1)

122

(3).

(4)

(5)

(6)

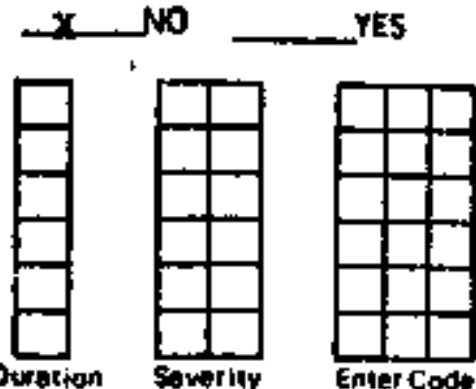

2. Might the activity affect wildlife or lishories?

If VES. specily wildile or lisheries affected:

$\times \quad \mathrm{NO}$

YES

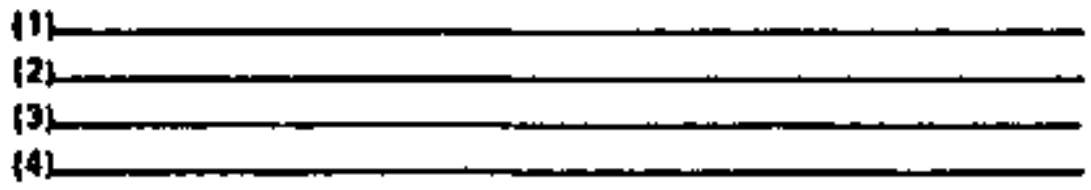

$f$ VES, specify whether eny rere or endangered wildlife or fisheries species might be offected:
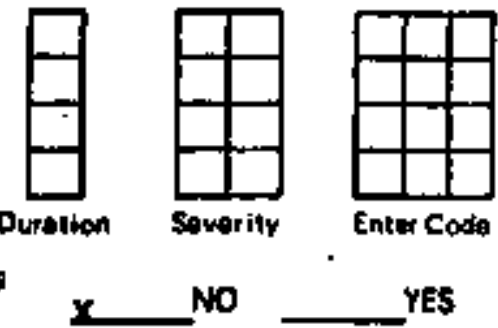

YES

3. Mtoht the actlvity affect natural vegetation?

If YES, specily vegetation and acreage(s) affected:
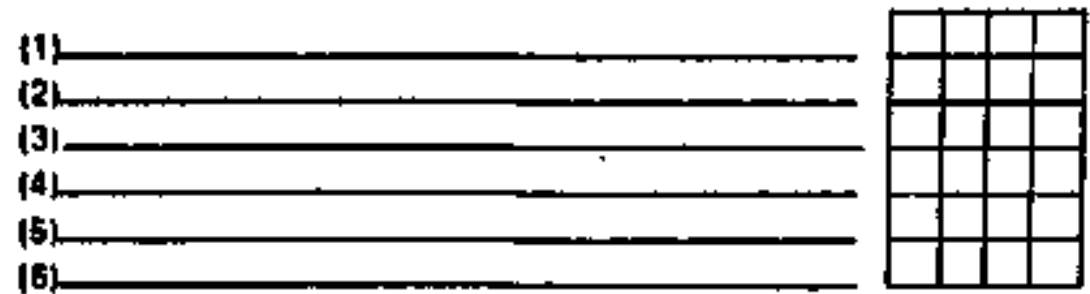

Acropose

If YES, 5pecify whether any rare or endangered plant species might be iffected:

4. Explanation:

D. ENVIRONMENTAL MAZAROS

1. Might the activity involve the use, storage, release of, or disposal of poientialty hazardous substances?

$\underline{x}$ NO YES

If YES, specify subsiance type and rate of usage:

(1)

(2)

(3)

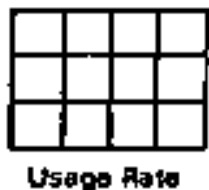

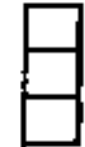

Duration

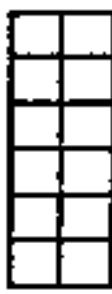

Savarity

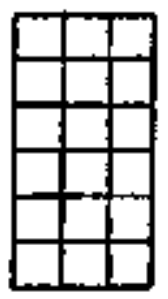

Enter Code YES

2. Might the aclivity involve altergtion of riverine floodplains, inland wellands, of coastal wetlands?

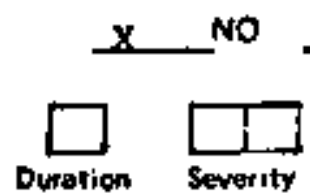

If YES, specify duration and severity of impact:

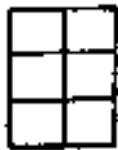

Sever ity

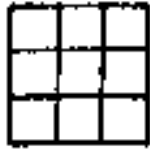

Enter Conde 
3. Wight the octlyity involve construction of other ectlon within owolpglcelty unstoble arees?

4. Enplanation: Operation of thie facllity does not require the use, storage or release of potentially dangeroug materlals. In addition, 1ta location is not near/or wetlands or a specifically unstable geological area. For these reasons, tho facility is not regarded as posing a potential environmental threat.

\section{E, heSOUACE CONSERVATION ANO USE}

1. Might the activity alfect or eliminate land suitable lor agriculturel or timbor production?

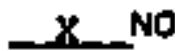

Y._. YES

if YES, spexify present apricultural land use ond respective acreage(s) offected:

(1)

(2)

(3)

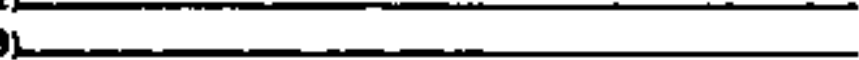

2. Wight the sctivity alfect potential use or extraction of an indispensable * wrete mineral or energy resource?

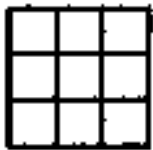

Acreso:

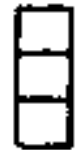

Durstion

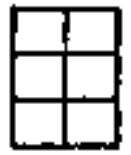

Saverily

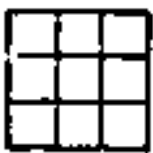

Envir Codo

If YES, specify resource affected and approximate amount:

(1)_oin

(2)

(3)

3. Explanation: As this facility is not located in an
excavation would be to nominal depths (no more

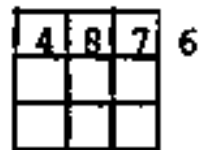

Tars
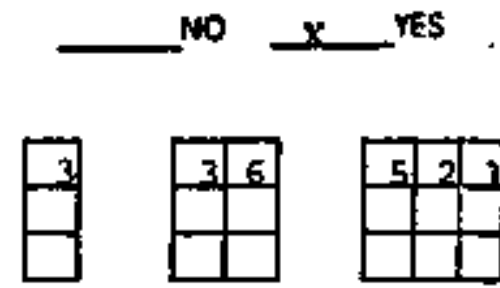

Owration

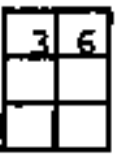

Sequerity

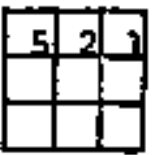

Enter Code than 12') in a shale ledge. ever. 6,000 barrelion of the ICES will result in a net savings of approximately national goal to decrease energy consumption.

F. WATEM OUALITY AND OUANTITY

1. Might the activity affect the quantity of water respurces, within, adjacent to, or near the activity area?

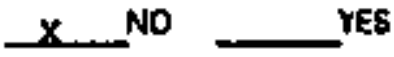

If YES. specily waler source affecled and respective emount lgatlons/dayl:

(11)

$|\mathbf{2}|$

(3)

(4)

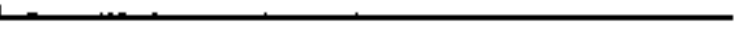

2. Might the octivity resutt in a deleterious effect on the quality of any water resource areas or watersheds?

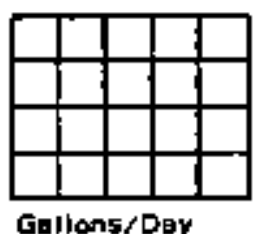

Gallons/Der

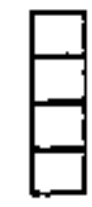

Duration

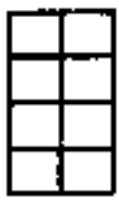

Sover ity

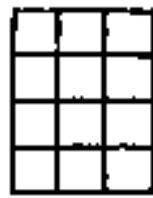

Enter Code

If YES. specily water resource that might be affected:

(1)

\{2\}

(3)

(4)

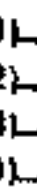

$\times \quad 10$

YES

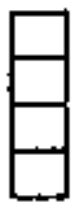

Distion

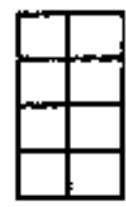

Severtty

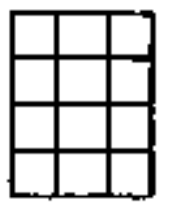

Enter risule 
If TES, opecily posslble substance cavolng offects:

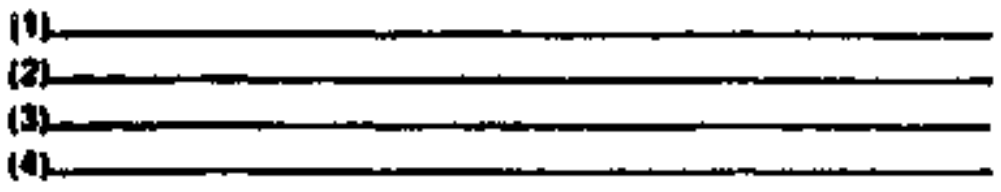

3. Enplonation: .
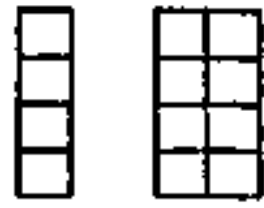

Duration

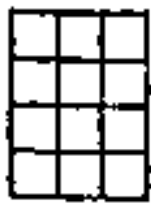

Eiver Code

\section{ARR OUALITY}

1. Mligh the activity atfect the ait wality in the project area, immediately odjecient areas, of the Air Oubtity Control Region?

No

$\times \quad$ YES

II VS. tpecify possible substances affecting a ir quality:

i1) Construation - Dust

(2) Nttropen Oxides (Now)

(3) Panticiulate

(4) Hydrociabons flict)

(5). Sulphus D1oxide $\mathrm{SSO}_{2}$ \}

(6) Carbon Nonoxide $(00)$

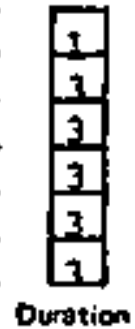

\begin{tabular}{|l|l|}
\hline 1 & 6 \\
\hline 7 & 6 \\
\hline 2 & 6 \\
\hline 2 & 6 \\
\hline 2 & 6 \\
\hline 2 & 6 \\
\hline
\end{tabular}

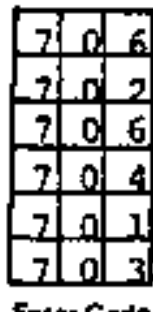

I VES, spocily wilther tny key receptors may be in the affected area:
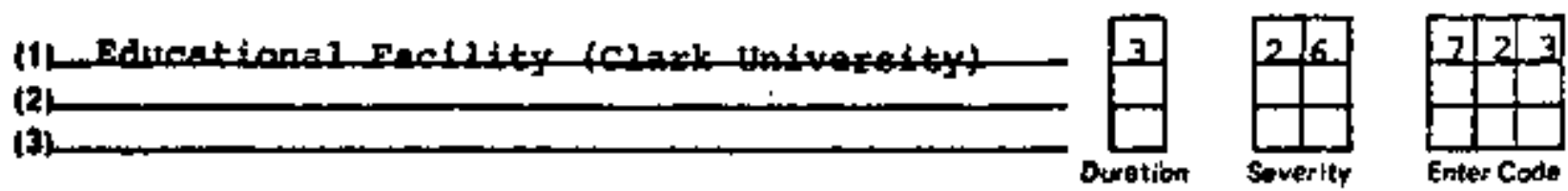

\section{Explanation:}

see attached.

H. NOISE

1. Wight the activbly pesult in the generation of nolse?

No

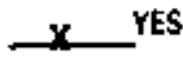

If res. specily noise source:

(1) Canstruction.

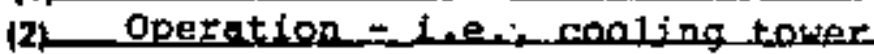

(3)

2. Explanation:

See Attached. 
G. 2. Explanation:

The operation of the alesel will affect the air quality 1n the project area to a minor degree. Ingtallation of TEP will alter a1r pollution impacts, not only because the TEP based syotem will use 1ene fuel, but, more importantly, because air pollution from internal combuation engines has a different character from that from furnaces. The greatest increases will be in amounts of $\mathrm{NO}_{\mathrm{x}}$ and $\mathrm{SO}_{2}$ emitted due to the high opexation temperature of the equipment. For the former, and high oulphur content of 6 residual odl, the increage In emiation io directly related to the lncreased capabilities of the new gyotom and muet be considered in 11ght of poselble reductiong reglonally owing to the overall expected decrease in oll coneumption.

\section{H. 2. Explanationt}

The propoed project 10 expectied to have an imperceptible nolde impact on the enviromont. Nolge levelo inslde the bujiding will meet the ogHA otandard of 85 DB. All measurea will be utilized ţo ineure against any disruption of the present environint, in and around clark Univereity. Conetruction nolee will be kept to a miniInum through the ube of heavily muffled equipment. wo negative noles impset 10 expected during the operation phase owing to uge of nolse abatement materials in construction of, and around, the equipment housing. 


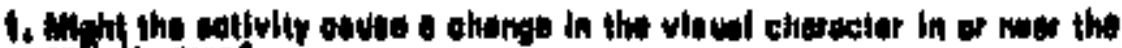
chiluty died?

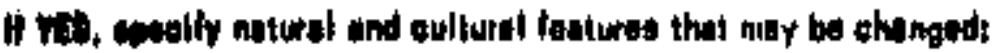

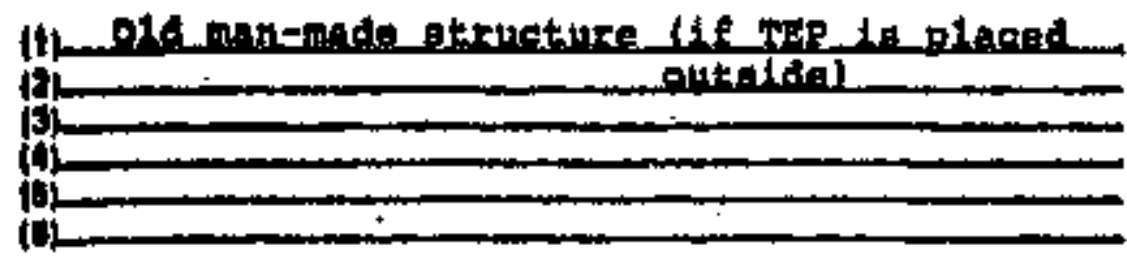

\section{Eaplandilont}

Bew Attsohed.

\section{J. Manvinge}

1. Wil the aetlylity require $\bullet$ verlance from of result in a polential violatlon of any atatute ardinance, by law, regulation, or standerd, the mojor purbon of which is to prevent or minimlze damape to the environment?

II het epactly variances and/or atatuas:

1. Will that aetivily require certification, Buthorlection, review of piam, of Inoushese of a permit by ony locel, state ar lederel epency?

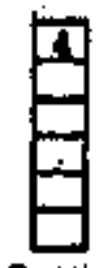

Butitian

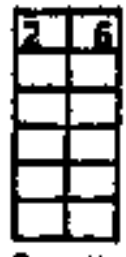

awarlity

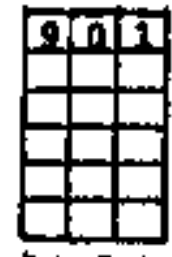

Inter Coda

\section{.} . $\$ 28$

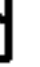
政 


\section{1. tixplanotiont.}

Wlth the conotruction of a new bullaing desdzred to housa clark's rotal Energy plant, a part of the Jonas Clark atricture, approxinhtely l seet high and to teat long will be obatructed. It lo the bel1et of the thritonmental Group that agethetic valuea added outweigh the loso

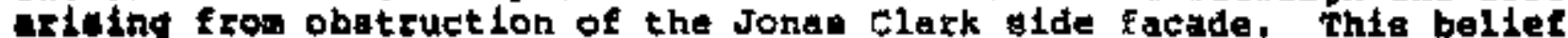
Idee in our conviction that an attractive structuze, as the one ptanned, allowing view of Plant operations, has grenter aesthet le value than the mall part of the facade that wili be obetructed. In edation, this feature will enhanee relatione with the comulity qurtounding clark ad the plant will provide an additlonal bite of interest on the campus. 


\section{N. Finotmes and centification}

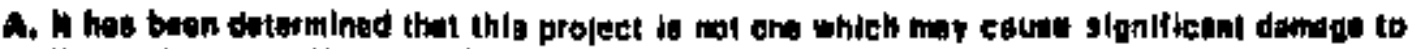

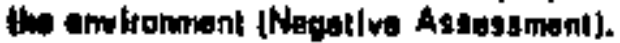

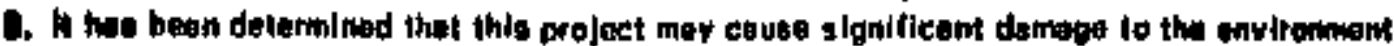

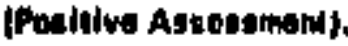

t. The daft Impact repert wht be oubmitted on of abouk:

2. The daft inpued report wilt be:

Standerd

Extenstive

J. The dratt impoet report will be combined:

4. the draft Impect report will be joint in conjunetlon with:

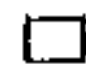

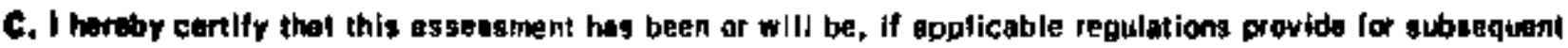
elirulotion, duly cinculated to the Attorney Generat, the oppropriate Regional Planning Agency, and ather nutew aponciee og requlfed by Appendik 8.

DATE

Bloneture al Preparing Officer (if different from Aosponsible Dfflcerl
Signuture of Responsible Oticer

(print of type) Name of Reaponsible Offlcar

Adidrese

Telephone Number 
4. Individuala and offiont Conaulted

Edeond O. Bonoit

Chief, Mir quality Control Gection

contral Maga Adr Quality piotrict

Teis cusson

Contral Mau Alr Quallty District

al Nick:

Nolee Pollution

BPA, Bonton

John tynoh

B.I.8, OfIles

BAA, Boston

Linde Murphy

Alr guslityi Now Bourdeo

EpA, Booton

Char1en o'connor

Offlee of Planning and Cormunity Development

Worcester, Masu.

Worton 8. Renmer, P.B.

Comminaloner: Departinent of Code Inspection

Clty of Worceater, Maselachusetts

419 belmont $g t$. 01604 


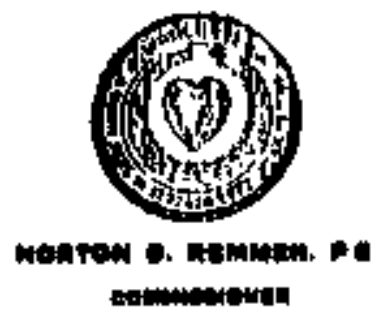

Mr, Lawrence Landry

Vlce President of Finance

Clark Untversity

950 Mala Street

Worcester, Mass, 01610

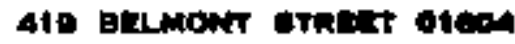

TELEPHONE IOI7, MaAd11

Dear Mr. Landry,

Th1s letter ull gerve to conflrm the conclugions reuchad at a meeting on Monday, April 11, 1977 relative to regulations controlling the proposed installation of mechanical faclistios at Clark University in conjunction with an ERDA dethongt ration project.

1. Zoning. In accordance with the Zoning Ordinance of Worc* ester and the official Mup the proposed use would not be in violation of zoning and could proceed routindy for approvel.

2. Batlding Code. There are no requltenents of the Bullding Code relative to tho proposed locations which were revdewed fur which coipliance could not be achleved by standard deeign and construct ion techn1ques.

3. All other requirements of the C1ty relative to conotruction baged upon the proposed preliminary concepts, would be oubject to routine procedures.

4. This office cannot take responsibility for State matudated and edministered requirements relutive to environmitatil into pact, and pollution controls. These items would huve to be reviewed by the appropriate unthorities.

5. Certaln Bollers and Unifind Presaure Vessels require approval by the Board of Boiler Hules of the State Defart-

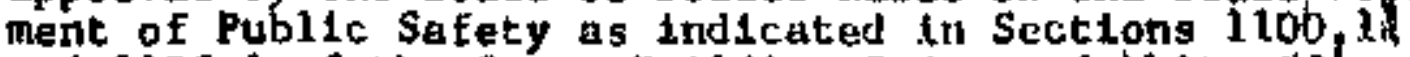
and 1103.1 of the State Buldding Code, and this old late would have th jurisdiction over those nppectals

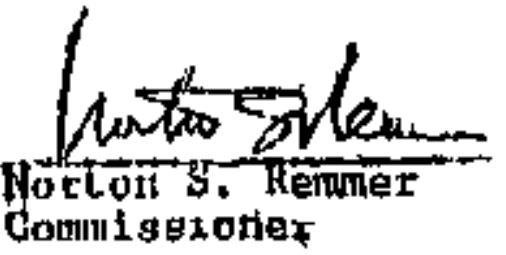




\section{DEPARTMENT OF CODE INSPECTION \\ CITY OF WORCESTER \\ MASSACHUSETTS 01604}

NORTON 5. REMMER, P.E. COMMISSIONER

$4 T 9$ BELMONT STREF ;

TEL 617-79GAIt

November 3, 1977

Hr. Lawrence Landry

Vice President of Finence

clark Univeraity

950 Malt street

Worceater, MA 01610

Dear Mr. Landry :

This Department previously subaitted a letter (copy

attached) relative to the installation of mechanical facilities

for generating power at Clark Univereity.

A review of the current proposed specifications has

not altered the decisions reached previously. W1thin those

areas for which this Department has primary legal respongibility

relating to the project, i.e., Building Code and zoning

Ordinance, I can aee no reason to expect that the project

as proposed would not meet zoning ordinance requi rements

or could not be conetructed in sccordance with the Building

Code of Its reference otandards, using standard degign and

construction techniques.

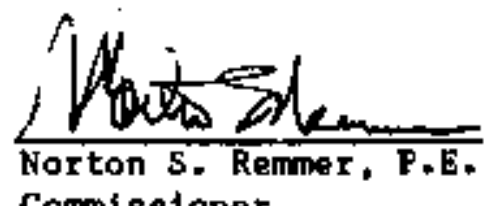

Commiseloner

NSE/eV

c.c. Mt. Herry Shwerz

Environthental Affelte Program 
$.103-$

APPENDIX 3A

Engine Operating Experience and Guarantees 
APPENDIX 3A

Engine Operating Experlence and Guarantees

Operating Experience

Both Sulzer and Superior have had extensive experience with the candidate engines burning distillate o11, Sulzer's experience has been with low-tenperature (1ess than $200^{\circ} \mathrm{F}$ ) water-jacket cooling, but they feel that the change to ebullient cooling is quite straightfoward. Superior's experience with their englne is largely with ebullient cooling.

We bolleve that the behavior of the engine when using residual oll is the wost sensitive question. Sulzer's experience with heavy-oil-burning engines is considerable, stace they have about 508 of the market for large marine engines. They also have heavy-oil experience with engines of the same design as the one proposed for Clark. They have run 6-cylinder ASL 25/30 engine in the 1abaratory fron $1969-1972$. They ircumul:al ad 1130 hours of operation, 880 on heavy Euel and 250 on distillate oil during break-1n, starting and stopping. The sodium/vanadium content of the fuel varied between 13ppn/76ppm and 27ppn/ 173 ppm. Measurements of wear were made after 300 hours of operation with the $27 / 173 \mathrm{Ne} / V$ fue1. The chromiun-plated top piston ring had wear of about $.00151 n c h / 1000$ hours, Liner wear was .0004 to, 000 Binch/1000 hours. No wear could be measured on valves or the piston ring grooves. According to sulzer, rate of wear on piston ring and liner drops to about $1 / 3$ of the fittial rate after about 5000 hours. Assuming this change is linear for the first 5000 hours and remains constant thereafter, the wear on the top piston ring woutd be .005 inch after 5000 hours and .0075 inch after 10,000 hours. The liner wear would be .00133 to .0027 1nch after 5000 hours and .0019 to .0038 tnch after 10,000 hours. Fron these values, Sulzer has predicted the 1 ifetimes of various component5. These predicted lifetimes are presented in Appendix 4B, Table 4B-1, where they are used to estimate maintenance costs for the engine. In addition to the test engine, two ASL $25 / 30$ engines have accunulated more than 10,000 hours burning residual in regular service.

Superior had 10 installations of their older in-line version of models 40, 60 , and 80 , engines designed for crude or residual oll. However, they do not know what the experience of these sites has been. We obtained useful information fron one of these sites, an eight-cylinder engine rat ed at $1000 \mathrm{kw}$ that has run about 107,000 hours for the florida Keys Electric Corporation in Marathon, Plotida, About $75 \%$ of those hours were for opesation between 1954 
and 1964 , using restdual fuel. In 1964 the p1ant changed to 2 oil as the price difference between $\# 2$ and $\$ 6$ oils disappeared. A further consideration was that the vanadium content in the available fuel had increased, and they were not see up to treat vanadium. A spokesman for Florida keys stated that wear on valves and other engine parts was not appreciably different for \#2 and 16 oils, except when there were high vanadiun levels in the oil (unfortunately the spokesman could not say definitely what a high vanadium level was). There was an increase in maintenance costs for such components as injectors, fuel pumps, and other fuel handling equipment.

To summarize, Sulzer has experience operating their candidate eng ine with residual fuels; Superior does not. Sulzer does not have experience with the ebullient cooling of their engine while Superior does. Both manufacturers have considerable experience burning heavy fuels in other engines, but Sulzer"s experience is probably more extensive as they are the larger company.

\section{Guarantee Terms}

Both companies offer us their standard guarantee. Sulzer will guarantee the engine for 12 months from the conmissioning of the power plant. The guarantee applies to an ebullientiy cooled, residual-oil-burning engine, but the engine must maintain linits of sodiun/vanadium of $30 \mathrm{ppm} / 100 \mathrm{ppm}$. The guarantee covers repair or replacement of defective parts; the details of the guarantee can be negotiated at the time of purchase. The guarantee will not cover nornal wear, inproper naintenance, incorrect operation, etc.

Superior's guarantee is similar. It is also for one year and covers repair or replacenent of defective parts. Their guarantee requires regular monitaring of the fuel input to the engine to ensure that limits of sodium/ vanadium of $5 p p m / 30 p p m$ are not exceeded. 


\section{APPENDIX 3B}

\section{Plant Descriptions}

\section{ENGINES}

\section{A. Superior Engine}

The Superior engine is Model 40-X-16 ( $V$ type). It has 16 cylinders, $900 \mathrm{RPM}$, and is rated at 2120 bhp at $100 \mathrm{~s}$ load. The generator output at $100 \%$ load is $1500 \mathrm{kw}$. The engine has a break mean effective pressure of 141.4 at $100 \%$ load and is turbocharged. As currently available it does not use heavy oil. Cooper Energy systens has advised that with modifications the engine will be suicable for residual oll.

The following design charges would be necessary to make it capable of burning residual otl as fuel:

1. Injection pumps would require special clearanced plungers and berrels and have bypass to allow an adequate flow of oil through the plump far cooling.

2. The injection nozzles would require special clearances in the area of the valve and seat.

3. The injection nozzle tips would require low sac volume and an orifice size selected for the particular fuel used.

4. The fuel would require pre-treatment including, as a mininum, water washing and centrifuging. Preheating would al so be required to reduce the fuel's viscosity in order to make it more easily handied for the treatment necessary. We would be working with conmercially available manufacturers of fuel treating equipment to make the final selection. Once the fuel is treated, it would also require additional filtration at the engine. Further heating of the fuel may also be required before and after filtration depending upon the fuel viscosity.

5. The engine would be equipped with a duplex fuel systen which would allow the engine to start and stop on No, 2 diesel fuel and transfer to residual operation after the engine is runing. This will ensure that there is no $\$ 6$ oil in the engine when the block is cool.

6. Reduction in metallic alloys in the fuel systen may be requlred depending upon the amount of corrosives in the residual. Many residuals contain extremely high sulphur and water content which, under the right conditions, can forn corrosive acids. 
7. The use of a high total base number (TBN) lubricating oil would be required in the crankcase along with more frequent oil change periods. The high $T B N$ ofl has high alkaline reserve preventing acid build-up in the crankcase and minimizing corrosion in this ares. The manufacturer would Iike to have a minimum of one month available for testing an englne with the residual fuel selected.

B. Sulzer Engine

The Sulzer engine is Mode1 8 ASt 25/30 (in-line cylinders). It has eight cylinders, 900 RPN and is rated at 1984 bhp at 1004 load. The generator output at $100 \%$ load is $1405 \mathrm{kw}$. The engine is currently available as a residual oil engine. It has a brake nean effective pressure of 242,7 at $100 \%$ load and is turbocharged. There are two $A 25 / 30$ engines burning 6 oil. They have accumulated over 10,000 hours of service.

Both the 5uperior and Sulzer jacket and air cooler will be cooled by Glycol-to-air radiators.

II. STEAM SYSTENS (connon to Superior and sulzer engines)

A. The new diesel plant will utilize the existing deaerator, condensate system and feedwater pump of the university boiler plant.

B. A new waste hest boiler will be installed, This will be rated at approximately $2500 \mathrm{lb} / \mathrm{hr}$ at $125 \mathrm{psig}$ saturated stean. The unit will be equipped with a gas bypass valve to control stean pressure. The boller will be equipped with level controls, high and low water alams.

C. The ebullient jacket cooling system consists of supply and return piping to a stean reservolr separat or. The reservotr/separator will be equipped with level controls and high and low-level alarns. Make-up water to the system will be via a water softener. Pressure in the system will be maintained by a modulating steam value which will release the stean to the 15 psig system. Any steam not required by the 15 psig university systen will be condensed in a radiator condenser.

II I . FUEL SYSTEM

Two fuels are required for engine operation, No. 2 and No. 6. No. 6 oil is the basic fuel. No, 2 oil is used for starting and shut ting down the engine. The oil storage system will consist of an existing 20,000 
gallon No. 6 ofl storage tank and a buried 2000 gallon No. 2 oll storage tank. Two fuel oil transfer punps will be required, one for No, 2 oil and one for No. 6 oil. These pumps will be located in the diesel plant building. The No. 2 putp will take oil fron the No, 2 tank and pump to a 300 gallon day tank in the diesel plant. The No. 6 oil transfer pump will pump the No. 6 ofl fron the buried tank to the oll treatment system. After treatment, the oil will be pumped to an elevated 600 gallon oil storage system. Fron this point an engine driven pump will pump the oil to the engine,

IV. FUEL TREATMENT SYSTEM

The fue 1 treatment systen is described in Appendix 30 of this report.

V. ELECTR ICAL SYSTEM

The diesel generator will generate power at 13,800 volts. The unit will operate continuously, in parallel with the Messachusetts electric Power Systen. The existing Jonas Clark $208 \mathrm{~V}$ electrical system will be tied Into new switchboerd located in the diesel piant. This power will feed the auxiliaries and 1ighting $\mathrm{fc}^{-}$the diesel plant. The 13,800 power will be fed (via the new switchboard) to the Goddard Library via two buried conduits. At the distribution systen in Goddard, the power, whtch can flow into or out of Clark, w11l be metered in each direction. 
PLANT DESCRIPTION

DISTILLATE OIL ENGINE

I. ENGINE

A. The engine selection for distillate oil is the Colt Falrbanks-Morse, opposed piston, 9 cylinder, 720 PPM, rated at 2160 bhp. The generator output at 100 : load is $1531 \mathrm{kw}$. Th1s engine has many years of expertence and is recognized as a highly retiable engine.

II. STEAN SYSTENS

The steam system would be the same as for the heavy oil engines.

III. FUEL SYSTEM

The fuel system will consist of a 20,000 gallon buried distillate oil tank and transfer pump and a day tank from whtch the of 1 would be pumped to the engine by the engine driven oil punp.

IV. FUEL TREATMENT SYSTEM

There is no fuel treatment system required for the disti11ate ofl.

V. ELECTRICAL SYSTEM

This is the sane system as described for the heavy oil engine. 
-111 -

APPENDIX 3C

Performance of the Candidate Systems

I 


\title{
APRENDIX 3C
}

Performance of the Candidate Syst eins:

For each diesel generator considered, heat balance data were obtained from the engine manufacturer in terms of Btu $\mathrm{g} N \mathrm{~h}$ hh+hr. The heat balance parameters given by the manufacturer were:

\author{
Wort: rlutput \\ Jackel Water \\ lubricating oil Cissling \\ Exltuw:; Gases \\ Exhaust Latent Hedt \\ Radiation and Unaccounted
}

Exhaust gas flows and exhaust gus temperatures were also obtained from the engine manufacturer for each enginr evaluated. 'llis data was then used to obtain system heat balances, shuwhitg the amoutrt of $125 \mathrm{psig}$ and 15 psig stean flows.

A characteristic of diesel engines is that performance (1.e. heat balance in terms of $8 t w / k w h)$ is fairly constant down to about 50\% of design logd and then drops off substantially. We show this by showhing heat balances at 50 s 1 oad.

For each candidate system, the following assumptions were used to determine the best balances:

1. The deaerator in the existing heating plant was used.

2. The boiler blowdown was taken to be 5 \%

3. $95 \%$ of the stean was returned. The return temperature was $160^{\circ} \mathrm{F}$. The makeup water temperature was $60^{\circ} \mathrm{F}$.

4. The final feedwater temperature was $225^{\circ} \mathrm{F}$.

5. The boiler exit gas temperature for fired and heat recovery bojlers was fixed at $325^{\circ} \mathrm{F}$. The diesels were evaluated with ebullient $1 \mathrm{y}$ cooled jackets. An analysis of the campus heating system showed that the maximum average low pressure steam duty which could be utilized by the heating system was $2.4 \times 10^{6} \mathrm{Btu} / \mathrm{hr}$.

6. Heat balances were evaluated taking the efficiency of the conventional systens as either $75 \%$ or $85 \%$. The actual figure is near $75 \%$.

Figure 3C-1 is a schematic for the heat balance calculation for a diesel.

The heat rate for the engine was calculated by comparing the fuel requirements for the proposed demonstration system with those for the conventional systen. The fuel to the engine per Kwh is: 
$-113$.

FIGURE 3C-1

Schematic for Dlesel

Heat Balance

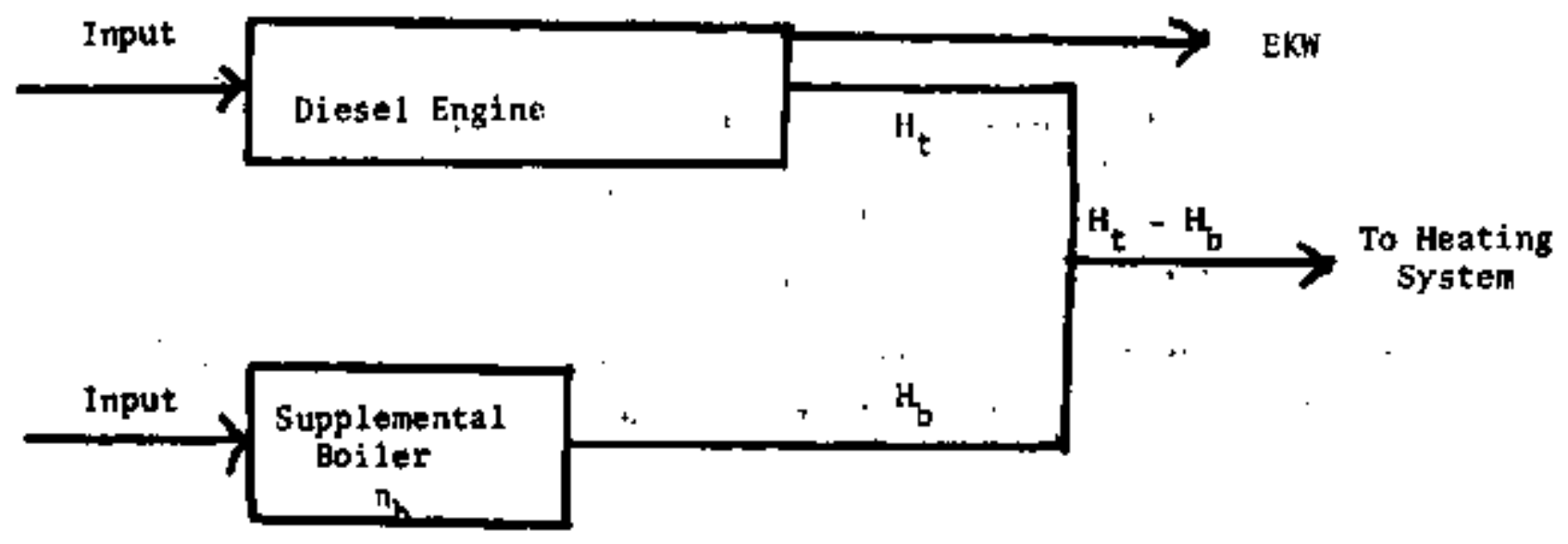

PROPOSEO SYSTEM

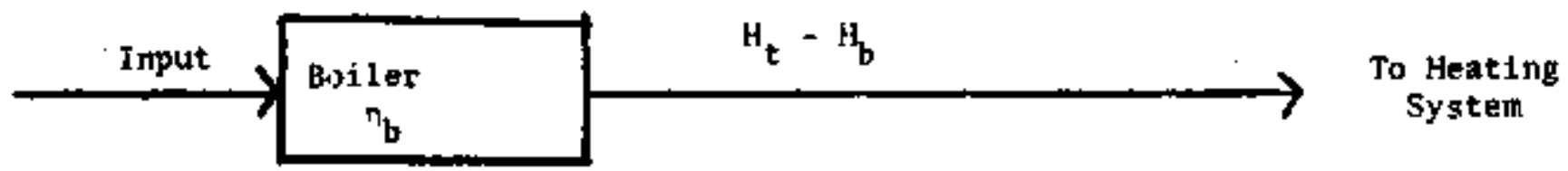

CONVENTIONAL SYSTEM 
EHR $=\frac{\text { lb fuel }}{\text { bhp-hr }} \times \frac{1}{.746} \times$ heating value (Btu/lb fuel)

where

EHR = engine heat rate (Btu/Kwh)

The total fuel per kwh used by the proposed system is then obtained by adding bojler fuel used to supplement the engine thermal outplit:

$$
\frac{H_{d s}}{\varepsilon_{T}}=E H R+\frac{H_{b}}{n_{b} \varepsilon_{T}}
$$

where

$H_{d s}=$ total fuel used by demonstration system (Gtu/hr)

$H_{b}=$ thermal output of supplemental boiler (Btu/hr)

$E_{T}$ a electriclty producel hy engine (XW)

The total fuel used by the conventional system is just the boiler fuel required to obtain the required thermal output.

$$
\mathrm{H}_{\mathrm{cs}}=\frac{\mathrm{H}_{\mathrm{b}}+\mathrm{H}_{\mathrm{t}}}{\mathrm{n}_{\mathrm{b}}}
$$

Subtracting equations 2 and 3 then results in the desired incremental heat rate:

$$
\begin{aligned}
H R & =E H R+\frac{H_{b}}{\eta_{b} E_{T}}-\frac{H_{c s}}{E_{T}} \\
& =E H R-\frac{H_{t}}{\eta_{b} E_{T}}
\end{aligned}
$$

We see from equation 4 that the term $H_{t} / \pi_{b}$ is the useful thermal output (from the exhaust and cooling jacket) generated by the diese1. It replaces boiler fuel which would have had to be utilized in a conventional boiler. This fuel is therefore credited to the diesel.

Another key parameter is the cost of fuel attributable to generation of electricity. This is the cost of fuel for running the system less the cost of fuel that would be used in the existing boiler to make up the heat output of the candidatio system. This can be expressed 


$$
f_{T}=f_{e} \times E H R-\frac{f_{b} \times H_{t}}{n_{b} \varepsilon_{T}}
$$

where

$$
\begin{aligned}
f_{T}= & \text { cost of fuel attributable to generation of electricity ( } \$ / \mathrm{Kwh}) \\
f_{e}= & \text { price of fuel used in engine }\left(\$ / 10^{6} \mathrm{Btu}\right) \\
E H R= & \text { fuel input to engine (or high pressure boiler for a stean } \\
& \text { turbine) (Btu/Kwh) } \\
f_{b}= & \text { price of fuel that would be used in a conventional boiler } \\
& \left(\$ / 10^{6}\right. \text { Btu) } \\
H_{t}= & \text { useful themal output of system (Btu/hr) } \\
\pi_{b}= & \text { efficiency of conventional boiler }
\end{aligned}
$$

The derivation of equation 5 is similar to that for the heat rate, equation 4. When the same type of fuel is used for both the engine and the boiler, or when the costs for these fuels are equal, $\mathrm{fc}_{\mathrm{T}}$ is simply the fuel cost multiplied by the heat rate.

The performance data for three engines, the Sulzer $1405 \mathrm{KN}$, the Superior $1500 \mathrm{KW}$ and the Falrbanks Morse $1531 \mathrm{~kW}$ are shown in Table $3 \mathrm{C}-1$.

The heat balances themselves for full and half-load are shown in Figures $3 \mathrm{C}-2$ to $3 \mathrm{C}-6$. 


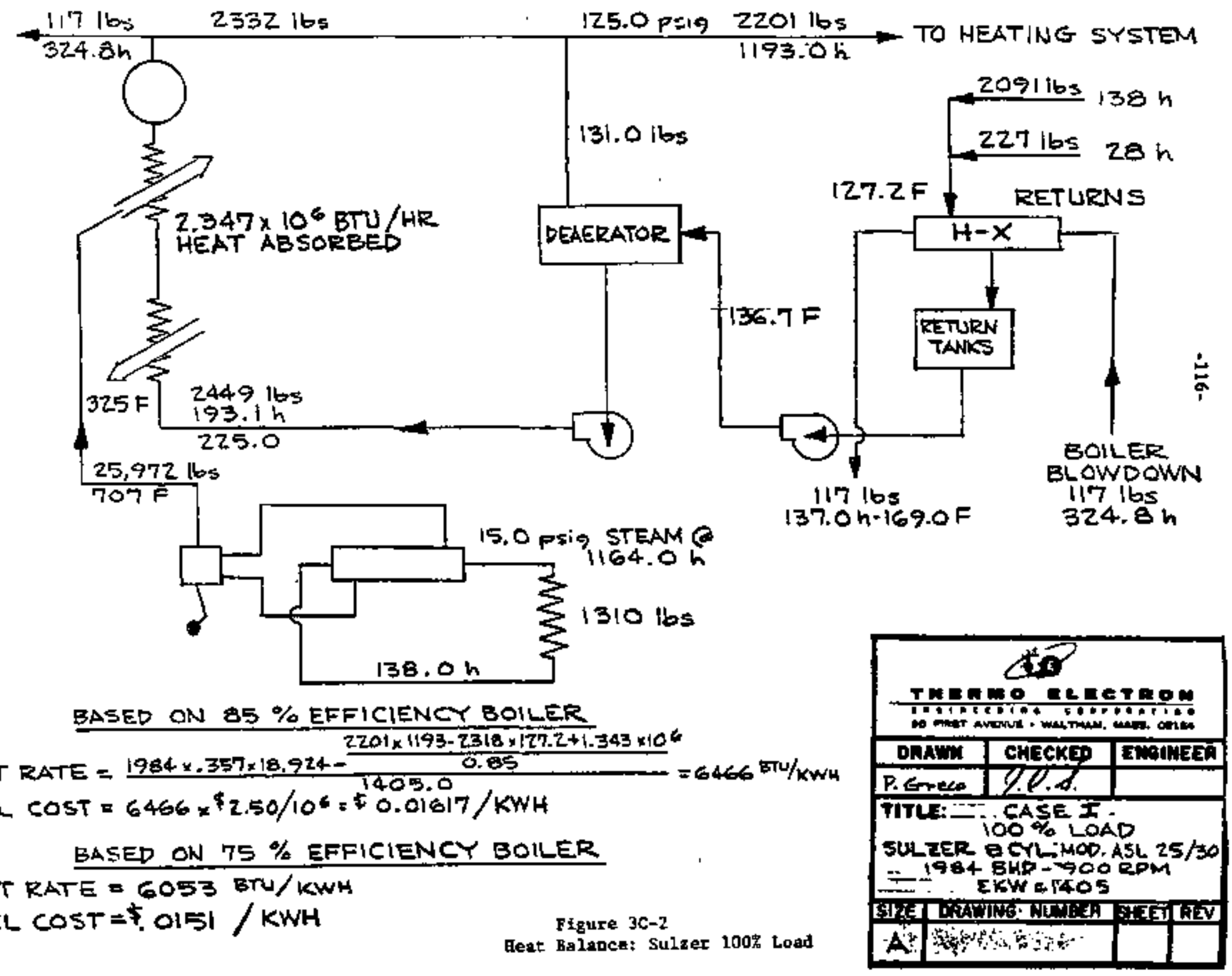




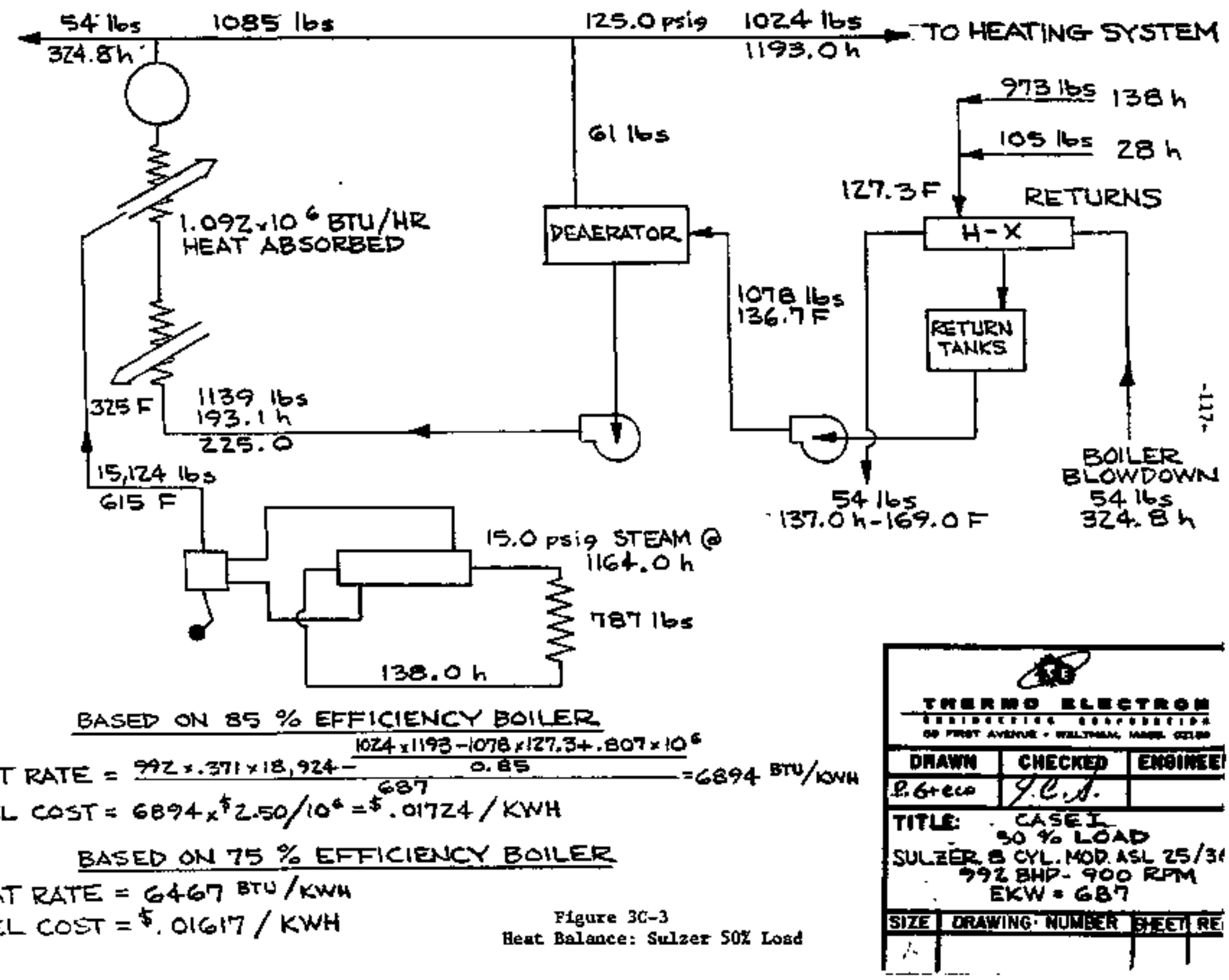




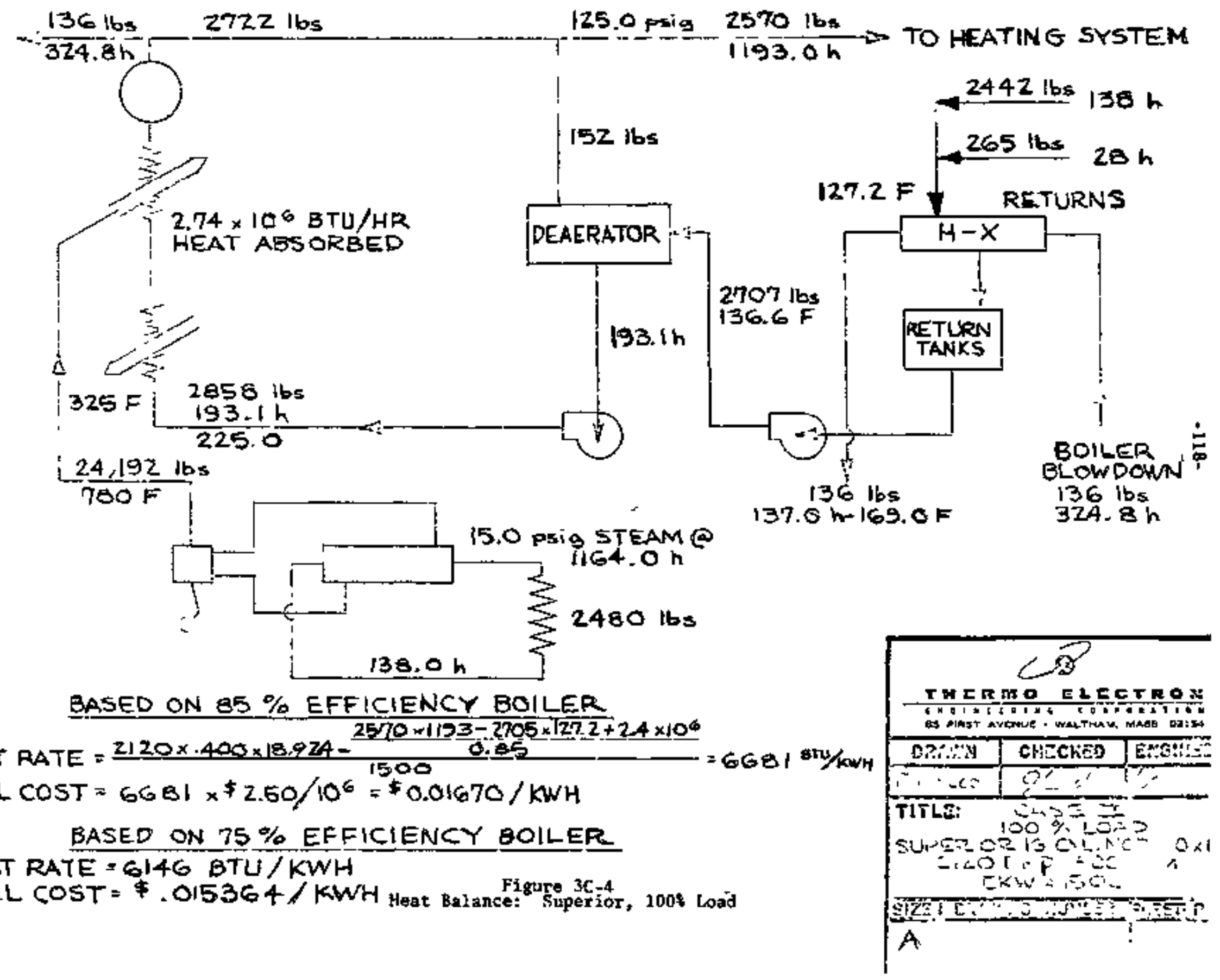




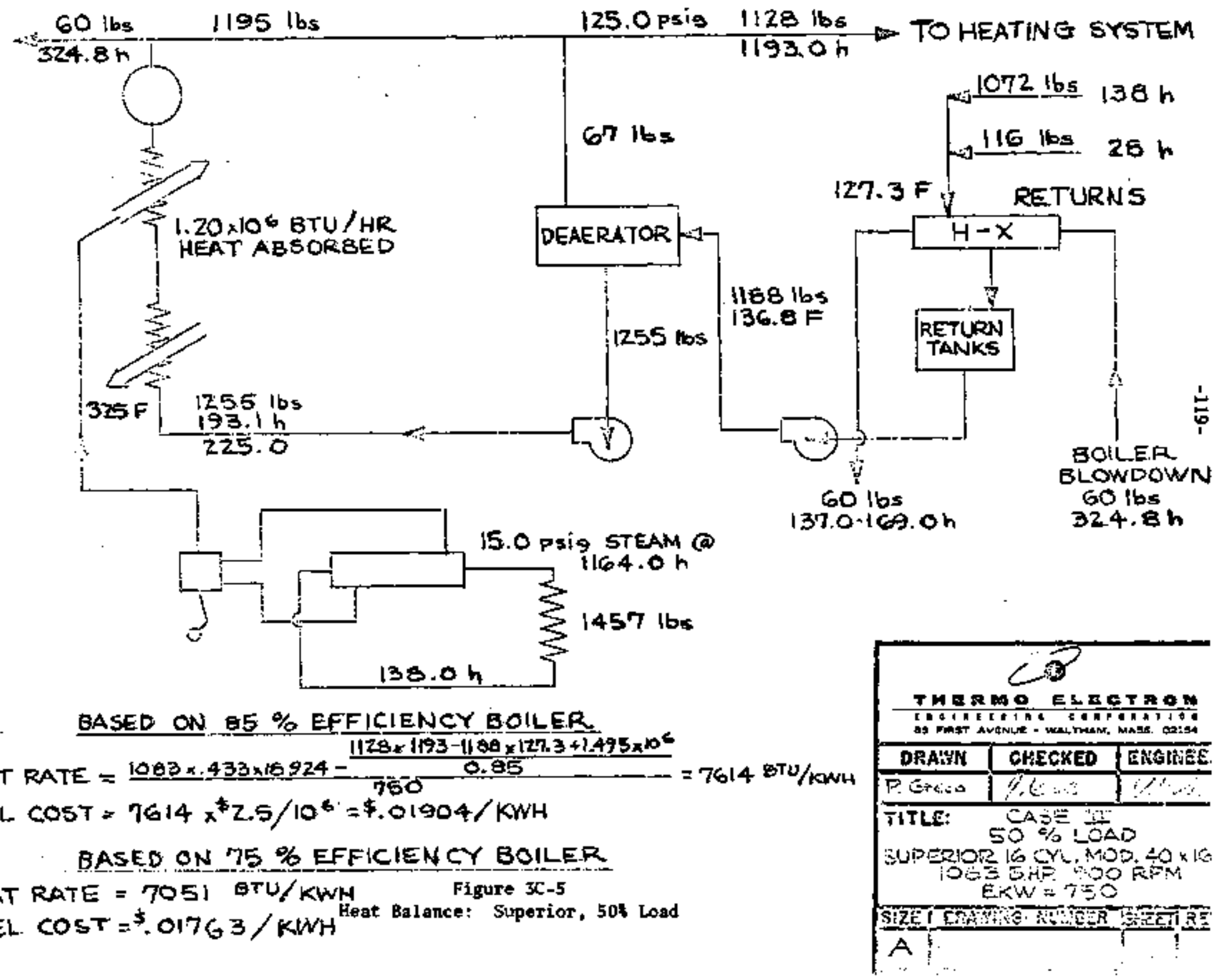




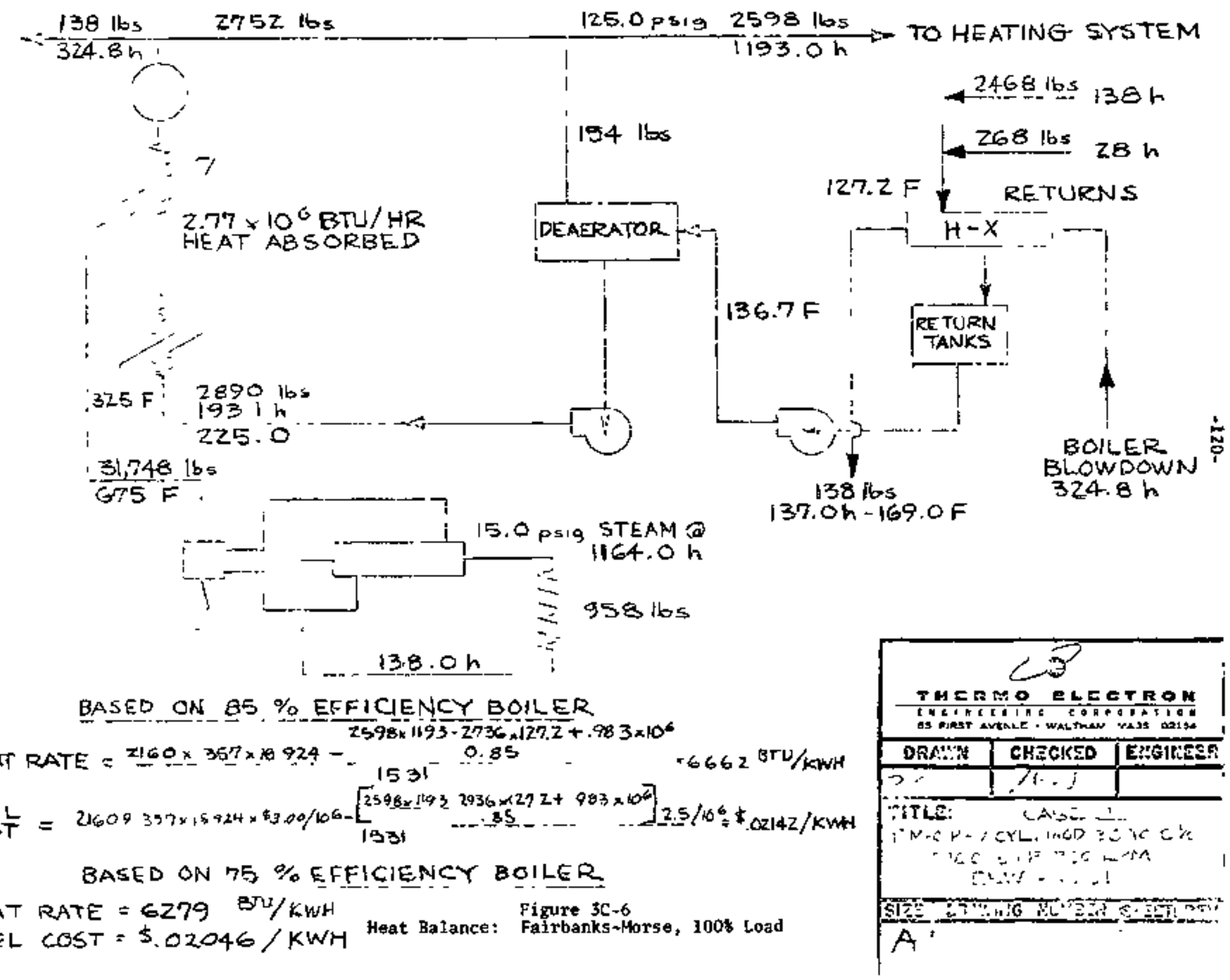




\section{APPENDIX 3D}

lieavy Fuel Treatment System 
APPFNDIX 3D

Heavy Fue1 Treatment systex

The 120 GPM integrated heavy fuel treatrent system con perform the following operations:

1. Heating the raw fuel.

2. Infection of demsisification agent.

3. Centrifugal desalting and sludge removal resulting in reductions of water-soluble metallic satts such as sodium, potassiun, lead, calciun, etc.

4. Fuel managenent linvolving inhibition of vanadium via magnesium sulfonate, residual to dist11late transfer capobility, filtration and puping.

5. All control and supervisory equipment for fully autonatic operation, of the entire systen.

The systen will reduce the sodium and vanadiun content of the fuel as follows:

\begin{tabular}{|c|c|c|}
\hline & Influent Oil (representative valueg) & Effluent 0il \\
\hline $\begin{array}{l}\text { Sodiun } \\
\text { Vanadiun }\end{array}$ & $\begin{array}{l}200 \mathrm{PPM} \\
200 \mathrm{PPH}\end{array}$ & $\begin{array}{l}<5 \mathrm{PPH} \\
<30 \mathrm{PPH}\end{array}$ \\
\hline
\end{tabular}

Part of the sodium is water-soluble. Therefore, water (about $18 \mathrm{GPA}$ ) is first mixed with the fuel in a mixer. The fuel is then centrifuged. The single-stage centrifuge separates and removes water-soluble and nonsoluble sodium, potassium, lead, calcium and nagnesium. The purifying effect of the centrifuge is dependent on the product of flow rate and the (kinematic) viscosity of the oil at the centrifuging temperature. This product pust be small. The effluent $1 \mathrm{~s} 998$ water with the above getallic soluble plus approximately 18 oil. This oil is removed in a skiming tank where the ofl content 13 reduced to less than $80 \mathrm{PPH}$.

After the centrifuglng, the vanadium is treated. Organic vanadium is extrenely corrosive in high-temperature areas of an engine. Because it is not very soluble in water, it is difficuit to remove. Instead, it is made noncorrosive by combining it with magnesiun prior to combustion in a ratio of a minimug of three parts of magnesiura (by weight) to each part of ranadiun (by weight). He will treat the vanadium with oil-soluble magneslup sulforate. This chentcal is available in the compercial product tretolite (KI-16) which is widely used in industry. Tretolite has 8 magnesiun sulfonate and a 
density of $9.25 \mathrm{lb} / \mathrm{gal}$. See section $4 \mathrm{~b}$ for cost analysis.

The following equipuent modules will be required:

Centrifugal Desalting stid consisting of :

One solids efecting centrifuge, capable of processing $120 \mathrm{gPH}$ of the spectfied fuel.

One (1) Nixer for blending fuel and water.

One (1) Water systen with punping, heating and flow control.

one (1) Heat exchanger for heating fuel complete with appropriate tempersture controls.

Above skid will also include:

Demulsiffer systen consisting of netering pump, level switch, gauge glass and calibrated metering glass.

Inhibition system for appropriate addition of oil-soluble tagnesion additive. Basis for design: 360 PPM vanadiun,

$3 / 1$ Hg to $V$ ratio.

Controlg consisting of starting circults for all notors with

approprinte termination points for easy interconnection to field terminals.

Fuel manggement skid consisting of a 100 gallon receiving tank for treated fuet, high-1on controls and agitator.

The building must be properly ventilated and be equipped with an over. head crane providing access to all equipment.

The systen flow diagram is shown on Figure 3D-1. Figure 3D-2 is a key drawing giving instrumentation symbols.

Utility Requirements:

1. Electrical power -- 208/3/60 - $13 \mathrm{KH}$

2. Ałr (instrument quality) $=100 \mathrm{psig}-5 \mathrm{~kg} / \mathrm{cm}^{2}$

3. Water (potable and 1ess than 25 PPM Nat)

$40 \mathrm{ps} 1 \mathrm{~g}, 60^{\circ} \mathrm{F}$ with nominal flow capability of $12 \mathrm{GPH}$

4. Steam -. saturated 15 psig, approximately $601 \mathrm{bs}$. per hour

Process Additives:

1. Demulsification agent:

Dosage

Source

Identification

2. Inhtbition of Venadium:

Dosage

Source

Identification
Nalco Chenical Company or Tretalite

Nalco 9-537DA or Tretolite RI-35 


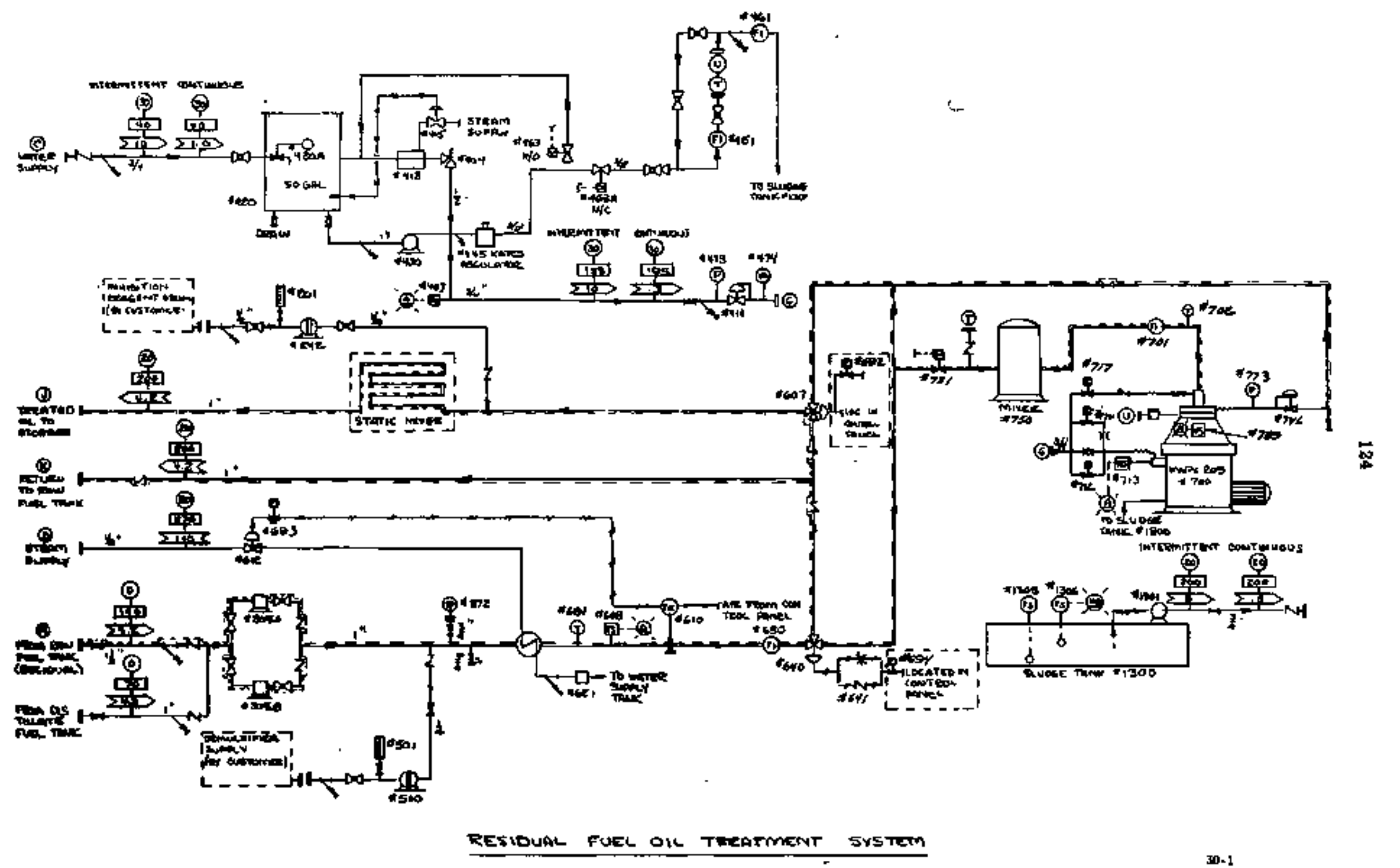




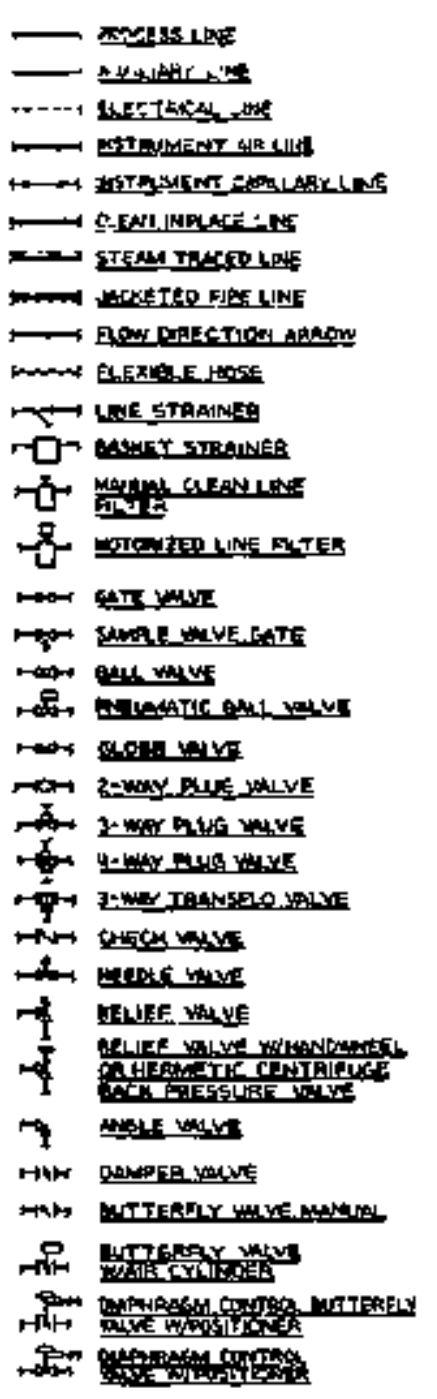

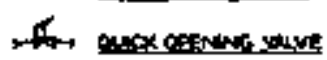

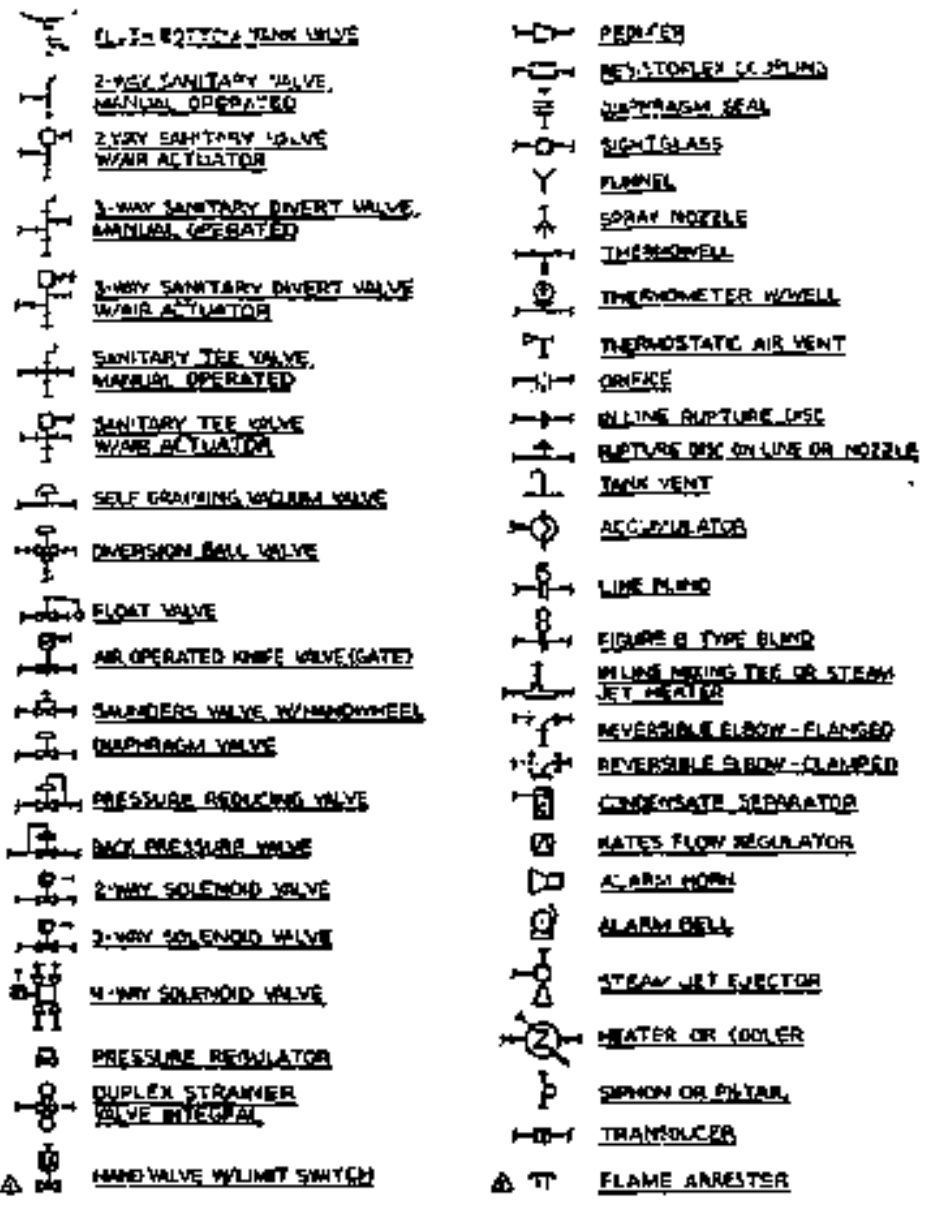

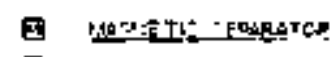

(1) Vist-Fostatsaxt

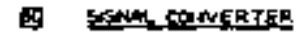

a vemuntron

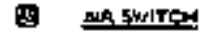

EI OARSGLAE ENHTTCH

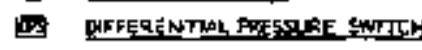

(1) LUMIT SMnTEH

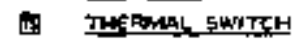

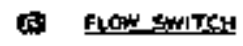

(1) ELReT stritay

厉

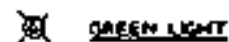

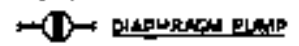

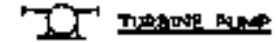

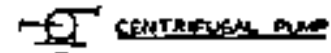

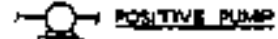

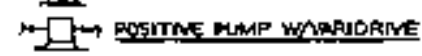

믈

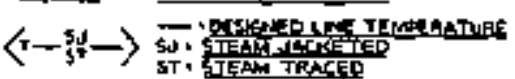

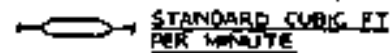

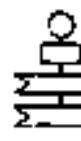

\section{extis}

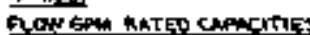

gowesh artep sapacitues

VENT

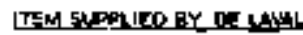

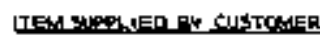

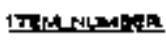

De

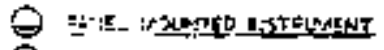

(4) voc $x$.

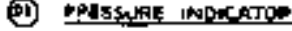

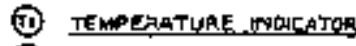

(ii) LEVIL NDECATOS

(iii) Lew inarats

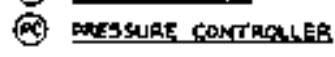

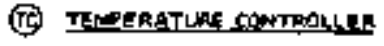

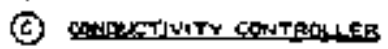

(3) IfVEL CONTAOLLLF

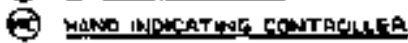

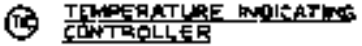

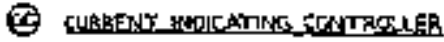

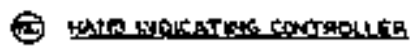

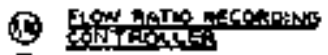

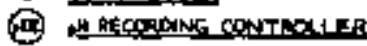

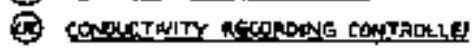

(19) ROW RECORDES

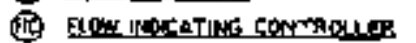

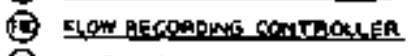

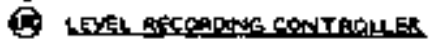

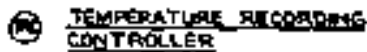

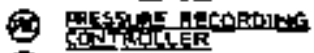

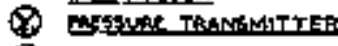

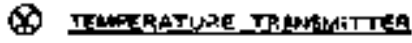

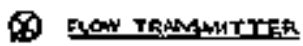

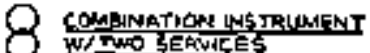

(iii) Lin Levé Iropach

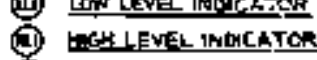

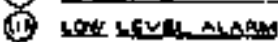

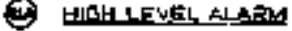

(1) SLOW NETES 


\section{APPENDIX 4A}

Detailed Capita1 Cost Analysis

We present here, in Tables $4 A-1$ and $4 A-2$, an undate of the Phase $I$ capital cost analysia, We have made the following inportant changes: (1) We have conputed costs for installation in a new bullding. (2) we have obtained costs for two new engines, the Sulzer and Superior. (3) We have made estinates, based on manufacturers' quotations, for the cost of a 6 oil fuel treatment sygtem. [4] He have reviewed our previous cost estinates and wade changes where necessary.

Our corplete capital cost analysis is shown in Table 4A-1. The total costg for the Supertor, Sulzer, and Falrbanks-Morse systens are nbout $\$ 1,320,000, \$ 1,382,000$, and $\$ 1,187,000$, respectively. It should be noted that these are costs to Clark; grid connection and specisl instrumentation w1l cost about an additional $\$ 90,000$.

Abong the costs we reviewed were the engineering cost estinates. Our new estinate is shown in Table 4A-2. The engineering costs from fine: design on are expected to be around $\$ 207,000$. The grand total shown includes feasibility and preliminary design and is our estinate of the total engineering costs to another site duplicating the clark systen, the costs include engineering of the fuel treatment system. We expect the engineering of the 2-burning Fairbanks-Horse system to cost about $\$ 7,000$ less. 
Table 4A-1

CAPITN COST ANALYSIS INSTDE NEN BUILDNG

MECHANTCAL Casts

Itew:

b.

1 Hripline and penarcter

2 Vibtation inolation

3 No. 6 oil engine dovelopint

4 Switchgoar

5 skid and piping for englna ad censrator

6 Service platforms and rails

7 Control ponl

8 Bngine frelgbe

9 Dhanst waste hatht bollor and controls

10 Jacket ebulliont bohlor ond cortrols

11 Jacket alt cosled ridictor, sandintar and controls

12 Jicket chroulinting witar ph

13 L.c. after coolet, ind turbo cooler Glycol rodiptor with जirnig tark

10 Witer saftaniers

15 Fupl ofl treatint byoten

16 Air coipresos for dtesal tartias and for instrumatation

17 Fire protettan

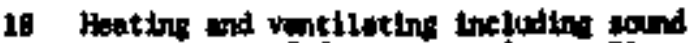
attinition of for poritratlons. Ploor and roof drains

19 Piptene and hurerer

ving:

Insulation

Intale Elltor

Inteke silencer

Buhbiat atiencer

Dowat afr trlet dinct

Dowal whoust the dict

th, 6 F.o. dy think (600 0.19)

2. Ho. 2 e.0. doy tonk [300 st1:.]

29 Pisl oil phips

50 Sludge tank - 4000 tols.

TOTAL MEDHANCAT

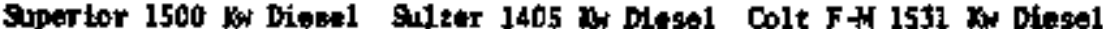
Residun oll Rasidunt oll Hodel 40-X-16

Hodel As 25/30

Distiliste os:

Hodel 3atps - $1 /$ o

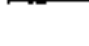

Totol Cost

$\$ 305,411$

5,375

27.172

40,006

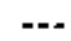

$--$

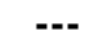

5,000

63,900

14,845

12,055

3,300

6,440

4,000

111,240

10,000

- 25,000

40,000

20,000

1,000

5.7014

5,000

5,000

2,500

$\$, 500$

4,000

- 807,418
Totel Cont

- 44,704

3,375

-..

37, 77

30,000

6,000

0,060

2, 500

54,765

13,500

10,550

2,900

5,500

4,000

04,500

7,000

10,000

$+25.000$

40,000

20,000

0,000

4,000

5,700

5,700

5.0010

5,000

4,000

2,500

5,500

0,00

(4) 49,37t
Totet Cost

- 430,000

5,575

...

Included In Iter 1
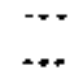

5,000

54,766

13,500

10,350

2,900

5,500

4,000

7,009

10,000

$+25,000$

40,000

20,000

$0,00 \mathrm{G}$

4,000

5,700

5,700

5,000

5,000

$\rightarrow-$

2,500

5,500

IE

- 600,701 
Table 4A-1

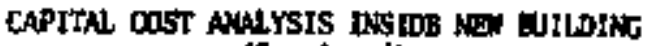

(Continued)

Itam

No.

CIVIL WORK

1. Maw butiding $-37 \% \times 60 \mathrm{~W} \times 204$ Inclutlng:

a. All foundations and exterior wals of brick and concete block with wifired proofed structurel steel, bar joirts and mopustical roof deck.

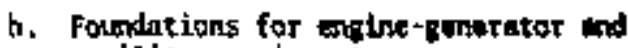
eyxiliary equifrogit.

c. An opening into the existing bollor roon ptotected by a Class A sliding tite door.

d. 14 x 14 sound proofed overhedd door in the south wall.

e. An Internal empelope of corrupated and perforsted aluninum ecoustical treitt obert on all wils and celing.

f. Crane horing a span of $30^{\prime}$ and 7 tons cepplatity.

g. is foot brick strick.

TORAL CNSL WOHK

$+255,000$

1255,000

$+255,000$

\section{ULETRICAL WORK}

1. Conections to generator set.

5,000

5,000

5,000

2. Lighting for generatoreren, wiring for controls, pups, heaters, vont listios syster and motor conerol cinter.

25,000

25, 000

\$5.000

3. biderground four act bank to the existing librory diștribution boand.

TOTAL, PLECTRICAL WORK

TOTAL INSTALLED DOST

DVGINagik ast To CLkK (Final Deslyo, Installation and 5tart-up $)^{\text {th }}$ TUTAL FaJET COST

\begin{tabular}{|c|c|c|c|}
\hline 21,000 & 21,000 & & 21,000 \\
\hline 51,000 & $5.51,000$ & $\$$ & $\$ 1,000$ \\
\hline$\$ 1,113,410$ & $11,175,373$ & $\$$ & 980,791 \\
\hline 207,000 & 207,000 & & $200,000^{n}$ \\
\hline$\$ 1,320,418$ & $\$ 1,31: 2,373$ & & 186,791 \\
\hline
\end{tabular}

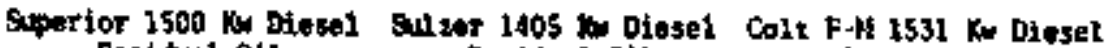
tegidual out

Bistillate 0il Hode 13 oTDe -1/3

Total Cont

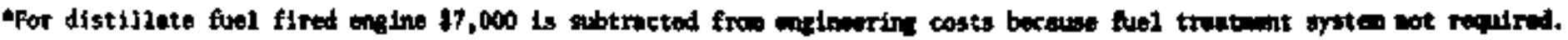
*rafer to table $4 A-2$, 
TABLE 4A-2

Engineering Cost Analysis

MAN $\cdot$ MONTHS

Engineering , Deșign Supervision
1.0 Engineering and econonic feasibility

1,0

2.0 Pre1lminary Design

Detailed layouts

Grid connection

Site and civil engineering

Environmental engineering

TOTAL
Detailed cost analysis

\begin{tabular}{ll}
0.5 & 1.0 \\
0.7 & \\
0.3 & \\
1.5 & \\
0.8 & 1.0 \\
\hline 3.8 &
\end{tabular}

3.0 Final Design

General arrangenent drawings

Flow diagrans

Electrical drawings and layout

Thermal distribution system drawings and design

Heat ing and ventilation drawings and design

Structural and accoustics drawings and designs

Engine systen specifications

Electrical specifications

Structural and accoustics specifications

Heat and ventilation specifications

Thermal distribution systen. specifications

Project purchases, schediles and construction plen

Construction cost budget

TOTAL

1.1

1.1

1.0

2.2

2.5

2.0

0.2

1.0

0.4

.5

2.0

2.0

1.9

1.0

2.0

1.0

1.4

1.0

2,0

$\frac{0.5}{15.2}$

$\overline{\mathbf{1 1 . 6}}$

\subsection{Installation}

kngine installation

Electrical installation

Civil and architectural installation

Heat and ventilation installation

Theraal distribution instgllation

Drawing changes

TOTAL

\begin{tabular}{rrr} 
& & 1.7 \\
& & 0.4 \\
.5 & & 3.0 \\
0.5 & 1.0 & 0.4 \\
\hline 1.0 & 1.0 & 0.2 \\
0.5 & & 0.2 \\
\cline { 3 - 3 } & & 5.9 \\
16.7 & 12.6 & 6.5 \\
21.5 & 14.6 & 6.4
\end{tabular}

GRAND TOTAL

$\$ 207,000$

design, Installation, Test and start-up)

GRAND TOTAL (Reptication Engineering Costs) 
$-131-$

APFENDIX AB

Gotetsen and Maintenance Costs 


\section{APPENDIX 47}

\section{Qperation and Maintenance Costs}

Operation and raintenence costs were estimated for the diesel engine, generator, boiler and accessory equipment. The estimates for the diesel engine were arrived at in consultation with representatives for sulzer and Superior. Operation and maintenance costs for other equipwent were estimated by Thermal blectron staff.

Sulzer reported that injectors should be removed and checked every 2000 hours and that this is an operation requiring 2 man hours. Their estinated 1 ifetine is about. 6000 hours. Annual checkups consisting of lifting the engine covers, checking valves, and pulling the plstons should be perforued every 6000-8000 hours of operation. Cost for these annual checkups, including labor and replacenent parts, (valves, lines, bearings, etc.) when required, anounts to about $\$ 10-12 / \mathrm{hp}$ over the $11 \mathrm{fe}$ of the engine. Expected lifetime of engine components is given in Table 4B-1 with estimated differences between distillate and residual oil use, 011 changes are recommended every 10-12,000 hours of operation. Sulzer reconnended increasing the resultant costs by 25 to obtain a conservative estinate for operation on residual fuel.

Superior recomanded checking the injector tips and changing the englne o11 every 1000 hours, but claim that the injectors last 20,000 hours. They recomend periodic maintenance inspection periods consisting of engine observation and checks by field service mechantcs every 2000 hours. They anticipate major overhoul periods every 20,000 hours. The najor overhauls would include replacenent of bearings, pistons, rings, and valves if required. Superior experience has been that the cost of the major overhauls for the worst case gas engines is about $\$ 14-21 / \mathrm{kwyr}$.

Both engines, Sulzer and Superior, require extensive fuel treatment of the residual oil. As explained in Appendix 3D, the two primary harnful Impurities in the residual oil are vanadium and sodium. Both must be reduced to tolerable levels to insure proper engine operation and minimum maintenance costs. The sodiun is removed by washing and centrifuping. The vanadium is treated with a magnesium-based conpound to form magnesfum ortho-vanadate ${ }^{1}$ which has a higher melting point than organic vanadium.

1 G.E. Krolls, Liquid Puel Treatment Systens, Geheral Electric Gas Turbine Reference Library, GER-2484, 1973. 
TABLE 4B-1

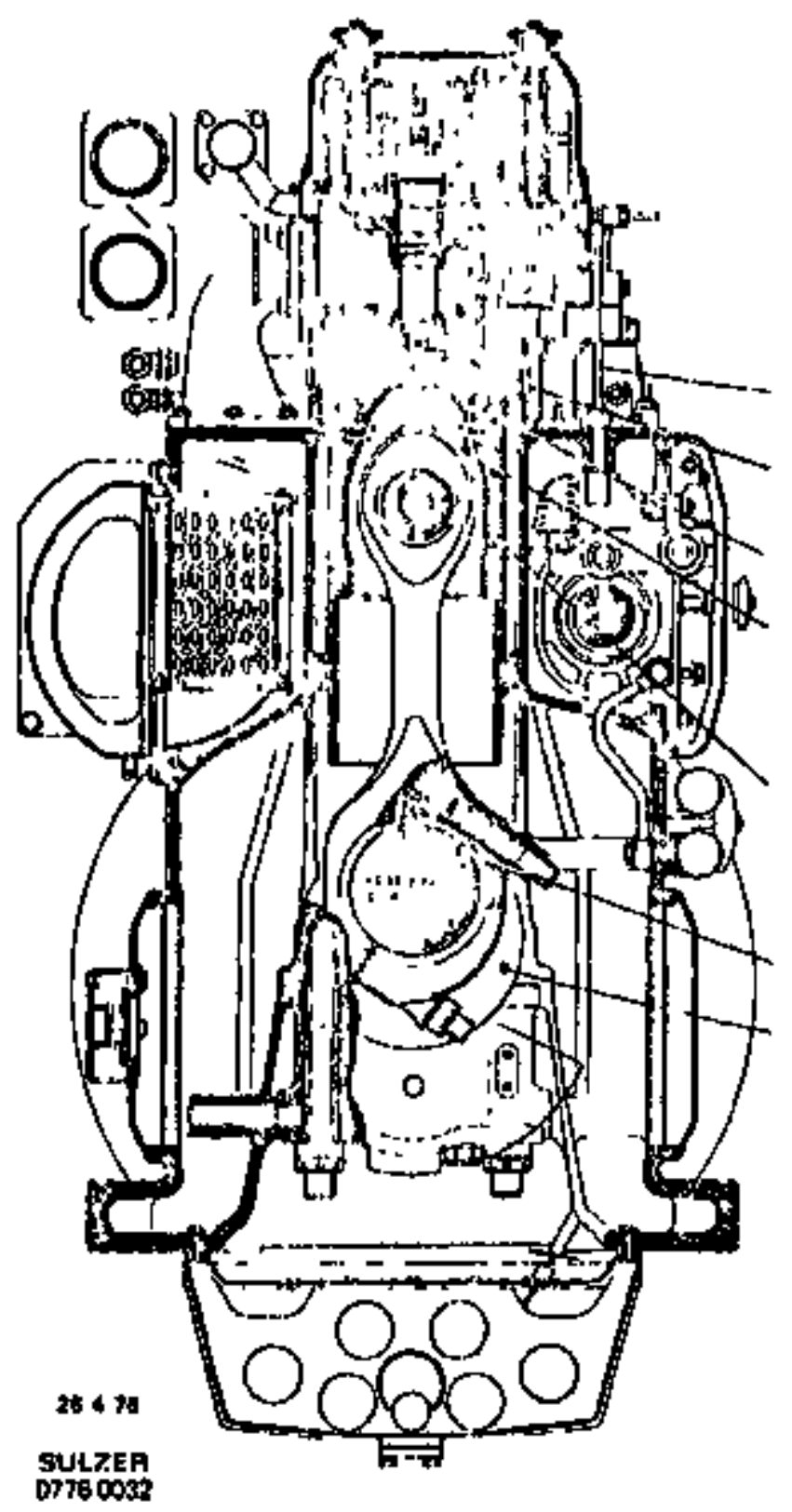

$A L 25 / 30$ and $A V$ 25/30

Expected lifetime of engine components due to wear (load factor $<0.9$ ) [hrs]

Injertion nozzle: above $\mathbf{6 0 0 0}$ Valves: $\quad(10000)$ above 30000 Top piston ring: $\quad 10000-15000$ Piston: above 100000 Piston ring groove: Oversized above $\mathbf{6 0 0 0 0}$ Liner: above 60000 Connecting rod bearings: $\quad 24000-48000$ Main bearings: $32000-64000$

Values depending on environment conditions and taking reconditioning possibilities into account 
This prevents deposition on the valves and cylinder walls. The anount of additive required depends on the content of the fuel and the anount that nust be renoved priar to use in the engine, anounting to about 3.2 parts of nagnesium per part of vanadium (by weight) renoved. Fusls avatlable in New England have a wide range of vanadiun content, from 50-250 PPH. For the purposes of this analysis we have assumed the vanadiuk content to be $150 \mathrm{PPM}$. Manufacturers' reconmended 1 irlts on vanadium content going into the eng tne are 11 sted in Table $4 B-2$. We see from this table that, according to manufacturer's experlence, the Sulzer englne cen tolerate greater limits on sodium and vanadium, Costs for neutralizing the vanadium are calculated In Table 4B-2, which shows that the cost of Tretolite KI-16 for the Superior engine is alnost a $\mathrm{kil} / \mathrm{kwh}$. greater than for the sulzer engine,

Table 4b-3 summarizes the operation and maintenance costs for both the Sulzer and Superior engine based on the abave discussion. Ne see fron Table 4B-2 and 4B-3 that the difference is attributable to the larger anounts of fuel additive required by the Superior englne for removal of the vanadiun. Other systen operation and maintenance expenses are given in Table 4B-4. Fron this table we see that the operation and maintenance costs are $5.7 \mathrm{mi1s} / \mathrm{kwhr}$ for the Sulzer engine and $6.6 \mathrm{~m} 1 \mathrm{~s} / \mathrm{kwh}$ for the superior engine. This can be compared to an expected cost of about $4 \mathrm{mils} / \mathrm{kwhr}$ for the distillatef1red $1531 \mathrm{KW}$ Falrbanks Morse with opposed piston described in the Phase $I$ report. 
TABLE $40-2$

MANUEACTURERS ' RECONIENDED LIHITS

FOR VANADIUN AND SODIUM GOING INTO ENGINE

$\begin{array}{lrc} & \frac{\text { sujerior }}{30 \mathrm{PPM}} & \frac{\text { Sulzer }}{100 \mathrm{PPM}} \\ \text { Vanadium } & 5 \mathrm{PPM} & <1 / 3 \mathrm{~V} \text { content }\end{array}$

Cost of Tretolite for Removal of Vanadiua from 150 PPM to Limits Inposed by Manufacturers

Sulzer (150 PPM to $100 \mathrm{PPM}$ )

$$
\begin{aligned}
& \frac{50 \mathrm{lb} V}{10^{6} 1 \mathrm{~b} \text { fuel }} \times \frac{3.21 \mathrm{~b} M g}{1 \mathrm{~b} V} \times \frac{1001 \mathrm{~b} \text { tretolite }}{81 \mathrm{~b} / \mathrm{g}} \times \frac{\text { gal tretolite }}{9.2 \mathrm{~S} \text { lb tretolite }} \\
& x \frac{0.504 \mathrm{tb} \text { fuel }}{\mathrm{kwhr}} \times \frac{\$ 5.00}{\text { gal tretolite }}=\$ 0.000545 / \mathrm{kwhr}
\end{aligned}
$$

Superior (150 PPH to $30 \mathrm{PPM}$ )

$$
\begin{aligned}
& \frac{1201 \mathrm{~b} \mathrm{~V}}{10^{6} 1 \mathrm{~b} \mathrm{fue1}} \times \frac{3.21 \mathrm{~b} \mathrm{Ng}}{1 \mathrm{bV}} \times \frac{100 \mathrm{lb} \text { tretolite }}{81 \mathrm{bMg}} \times \frac{\text { gal tretolite }}{9.251 \mathrm{~b} \text { tretolite }} \\
& \times \frac{0.5651 \mathrm{~b} \text { fuel }}{\mathrm{kwhr}} \times \frac{\$ 5.00}{\text { gal tretolite }}=\$ 0.00147 / \mathrm{kwhr}
\end{aligned}
$$


SUMMARY OF DIESEL ENGINE OPERATION AND MAINTENANCE COSTS

\begin{tabular}{|c|c|c|}
\hline$\cdot \cdot$ & $\begin{array}{c}\text { Sulzer } \\
\text { Type } 8 \mathrm{ASl} 25 / 30 \\
1405 \mathrm{kwe} \\
\end{array}$ & $\begin{array}{c}\text { Superior } \\
\text { Model } 40-x-16 \\
1500 \text { kwe } \\
\end{array}$ \\
\hline Injector Inspection and Replacement & $\$ 1,300 / \gamma r$ & $\$ 1,300 / y x$ \\
\hline $\begin{array}{l}\text { Annual Maintenance and Overhaul } \\
\text { (every } 6.8000 \text { hours) }\end{array}$ & 22,000 & \\
\hline Periodic Mafntenance/Inspection ** & 2,200 & 2,200 \\
\hline Major Overhaul (every 20,000 hours) * & & 26,500 \\
\hline 011 & g, 000 & 6,000 \\
\hline Sub Total & $\$ 33,500 / y r$ & $\$ 36,000 / y x$ \\
\hline Sub Total $\times 1.25$ & $41,900 / y r$ & $45,000 / y x$ \\
\hline Tretolite*** & 5,400 & $15,400 / y r$ \\
\hline Total Engine & $\$ 47,300 / y r$ & $\$ 60,400 / y r$ \\
\hline Total Engine/kwhr & $\$ 0.00481 / \mathrm{kwhr}$ & $\$ .000575 / \mathrm{kwhr}$ \\
\hline
\end{tabular}

*Includes major overhaul and replacement of all parts over 20 year life of engine.

** Includes oil analysis, replace filters, check fuel punps, valves, crankcase, balance cylinder temperatures, etc.

** Based on vanadium content in oil of $150 \mathrm{pPH}$ and treatnent with tretolite (8* $\mathrm{Ng}$ ) at 3.2 parts $\mathrm{Mg} /$ part $\checkmark$ and $\$ 5.00 /$ gal tretolite. 
TABLE $4 \mathrm{~B}-4$

SUMMARY OF SYSTEH OPERATION AND MAINTENANCE COSTS

\begin{tabular}{|c|c|c|}
\hline & $\begin{array}{c}\text { Sulzer } \\
\text { Type } 8 \text { ASL } 25 / 30 \\
1405 \mathrm{kwe} \\
\end{array}$ & $\begin{array}{c}\text { Superior } \\
\text { Mode1 } 40 \times X-16 \\
1500 \mathrm{kwe} \\
\end{array}$ \\
\hline Diesel Engine (see Table C) & $\$ 47,300 / y r$ & $\$ 60,400 / y T$ \\
\hline Generator & 2,000 & 2,000 \\
\hline Boilers & 1,600 & 1,600 \\
\hline Puinps & 1,500 & 1,500 \\
\hline Fuel Treatment System & 2,000 & 2,000 \\
\hline Miscellaneous & 2,000 & 2,000 \\
\hline Total Syster & $\$ 56,400 / y r$ & $\$ 59,500 / \mathrm{yr}$ \\
\hline Total Systen/kwhr & $\$ 0.00 \$ 73 / \mathrm{kwhr}$ & $\$ 0.00662 . \mathrm{kwhr}$ \\
\hline
\end{tabular}

